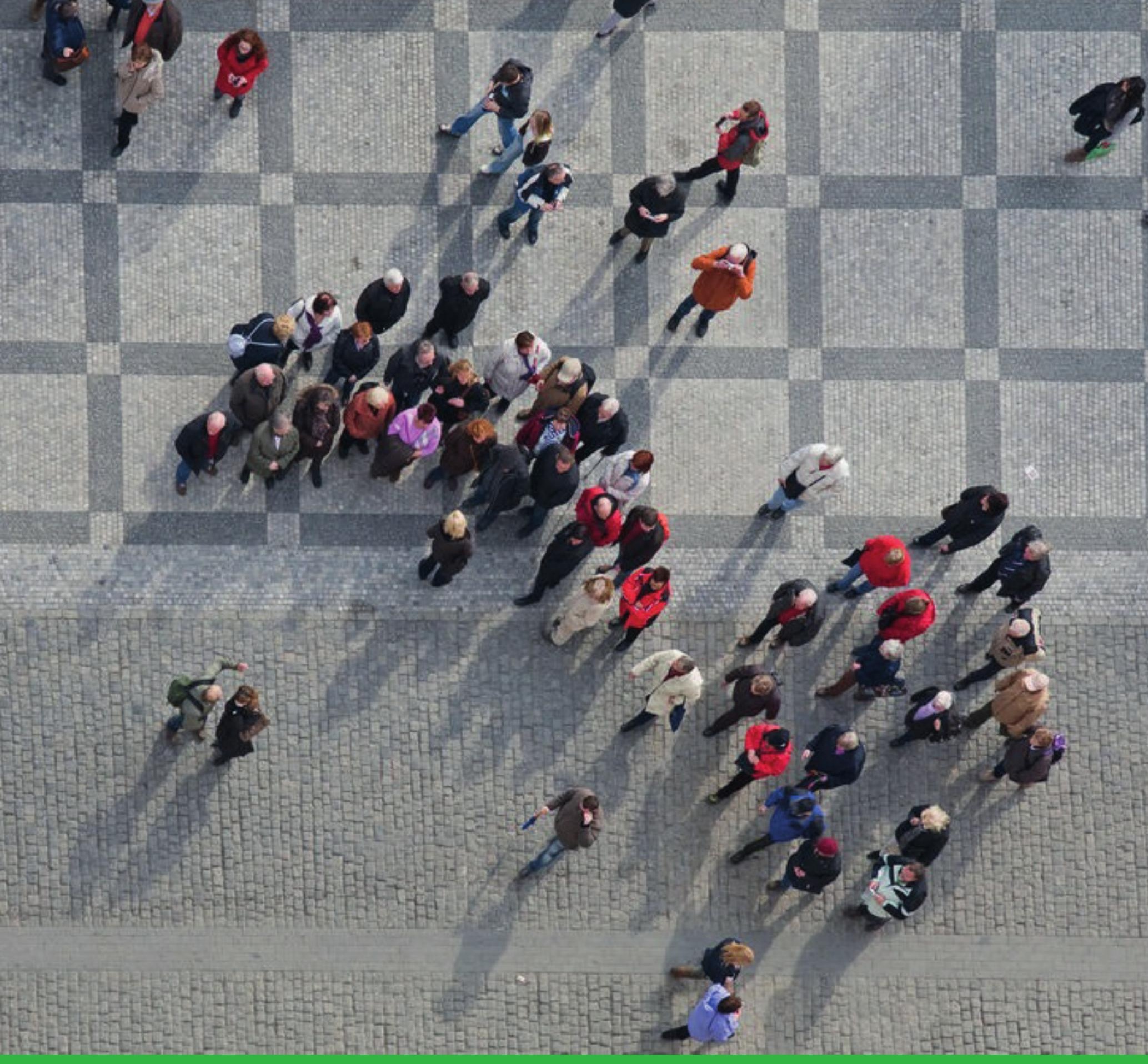

\title{
Beloopbaarheid gemeten
}

Pilotstudie naar de mate van beloopbaarheid van ov-knooppunten en hun buurten in de provincie Utrecht

C.M. Goossen, F. Rip, I. Staritsky, D. Thomas

WAGENINGEN

UNIVERSITY \& RESEARCH 



\section{Beloopbaarheid gemeten}

Pilotstudie naar de mate van beloopbaarheid van ov-knooppunten en hun buurten in de provincie Utrecht

C.M. Goossen, F. Rip, I. Staritsky, D. Thomas

Wageningen Environmental Research

Wageningen, juli 2021

Gereviewd door:

Ir. J.H. Spijker, senior onderzoeker, WENR

Akkoord voor publicatie:

C. van As

Rapport 3101

ISSN 1566-7197 
Goossen, C.M., F. Rip, I. Staritsky, D. Thomas, 2021. Beloopbaarheid gemeten; Pilotstudie naar de mate van beloopbaarheid van ov-knooppunten en hun buurten in de provincie Utrecht. Wageningen, Wageningen Environmental Research, Rapport 3101. 84 blz.; 18 fig.; 28 tab.; 60 ref.

Het is mogelijk om op basis van kwaliteitsindicatoren de beloopbaarheid van buurten en ovknooppunten te meten met data via een Geografische Informatie Systeem (GIS). Een loopscore kan worden berekend op basis van 160 indicatoren, onderverdeeld in 9 hoofdindicatoren: Infrastructuur, Omgevingskwaliteit, Directheid van voorzieningen, Toegankelijkheid, Levendigheid, Allure, Veiligheid, Aantrekkelijkheid en Bewegwijzering. In een pilotstudie zijn 103 indicatoren geoperationaliseerd voor 38 ov-knooppunten (waarvan 28 treinstations en 10 bushaltes) die gekoppeld zijn aan 151 buurten in 19 gemeenten in de provincie Utrecht. De loopscore geeft een redelijke indicatie van de kwaliteit waarmee beleidsmedewerkers inzicht krijgen in hoeverre gemeentelijke loopmogelijkheden voetgangersvriendelijk zijn en welke ingrepen wenselijk zijn om - in het kader van de Omgevingswet - de leefomgeving van burgers en hun gezondheid te verbeteren. Uit de analyse blijkt dat van de totale lengte aan loopmogelijkheden $58 \%$ een positieve loopscore heeft. Utrecht Centraal Station scoort het hoogst en treinstation Breukelen het laagst. Zamenhofdreef in de gemeente Utrecht scoort het hoogst bij de bushaltes en Rijnsweerd-Noord in dezelfde gemeente is de laagst scorende bushalte. De belangrijkste aanbevelingen zijn om ontbrekende data in het databestand te verzamelen en een gebruiksvriendelijk dashboard zal de tool bruikbaarder maken.

Trefwoorden: kwaliteit, loopscore, voetgangersvriendelijk, gemeente, ov-knooppunten, indicatoren

Dit rapport is gratis te downloaden van https://doi.org/10.18174/550567 of op www.wur.nl/environmental-research (ga naar 'Wageningen Environmental Research' in de grijze balk onderaan). Wageningen Environmental Research verstrekt geen gedrukte exemplaren van rapporten.

2021 Wageningen Environmental Research (instituut binnen de rechtspersoon Stichting Wageningen Research), Postbus 47, 6700 AA Wageningen, T 0317480700 , www.wur.nl/environmental-research. Wageningen Environmental Research is onderdeel van Wageningen University \& Research.

- Overname, verveelvoudiging of openbaarmaking van deze uitgave is toegestaan mits met duidelijke bronvermelding.

- Overname, verveelvoudiging of openbaarmaking is niet toegestaan voor commerciële doeleinden en/of geldelijk gewin.

- Overname, verveelvoudiging of openbaarmaking is niet toegestaan voor die gedeelten van deze uitgave waarvan duidelijk is dat de auteursrechten liggen bij derden en/of zijn voorbehouden.

Wageningen Environmental Research aanvaardt geen aansprakelijkheid voor eventuele schade voortvloeiend uit het gebruik van de resultaten van dit onderzoek of de toepassing van de adviezen.

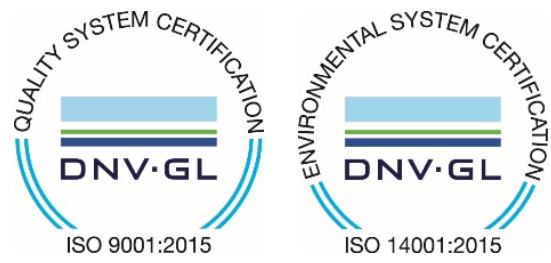

Wageningen Environmental Research werkt sinds 2003 met een ISO 9001 gecertificeerd kwaliteitsmanagementsysteem. In 2006 heeft Wageningen Environmental Research een milieuzorgsysteem geïmplementeerd, gecertificeerd volgens de norm ISO 14001.

Wageningen Environmental Research geeft via ISO 26000 invulling aan haar maatschappelijke verantwoordelijkheid.

Wageningen Environmental Research Rapport 3101 | ISSN 1566-7197

Foto omslag: Shutterstock 73233445 


\section{Inhoud}

$\begin{array}{ll}\text { Verantwoording } & 5\end{array}$

$\begin{array}{ll}\text { Samenvatting } & 7\end{array}$

1

Inleiding

11

$\begin{array}{lll}1.1 & \text { Achtergrond } & 11\end{array}$

1.2 Probleemstelling $\quad 12$

$\begin{array}{lll}1.3 & \text { Doelstelling } & 12\end{array}$

$\begin{array}{lll}1.4 & \text { Leeswijzer } & 12\end{array}$

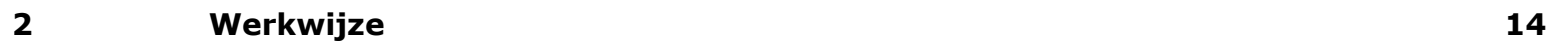

$2.1 \quad$ Inleiding 14

2.2 Indicatoren, ov-knooppunten en buurten 14

2.2.1 Indicatoren 14

2.2.2 Ov-knooppunten en buurten $\quad 15$

$\begin{array}{lll}2.3 & \text { GIS-data } & 16\end{array}$

$\begin{array}{lll}2.4 & \text { Loopscore } & 17\end{array}$

$\begin{array}{lll}2.5 & \text { Gebruiksvriendelijkheid } & 18\end{array}$

$3 \quad$ Infrastructuur $\quad 20$

3.1 Inleiding 20

$\begin{array}{lll}3.2 & \text { Buurtscore in de gemeenten } & 21\end{array}$

$\begin{array}{lll}3.3 & \text { Knooppuntscore openbaar vervoer in de provincie } & 22\end{array}$

3.4 Reflectie $\quad 23$

4 Omgevingskwaliteit $\quad 24$

$\begin{array}{lll}4.1 & \text { Inleiding } & 24\end{array}$

$\begin{array}{lll}4.2 & \text { Buurtscore } & 24\end{array}$

$\begin{array}{lll}4.3 & \text { Knooppuntscore openbaar vervoer } & 25\end{array}$

$\begin{array}{lll}4.4 & \text { Reflectie } & 26\end{array}$

$\begin{array}{llr}5 & \text { Directheid } & 27\end{array}$

$\begin{array}{lll}5.1 & \text { Inleiding } & 27\end{array}$

$\begin{array}{lll}5.2 & \text { Buurtscore } & 27\end{array}$

$\begin{array}{lll}5.3 & \text { Knooppuntscore openbaar vervoer } & 28\end{array}$

$\begin{array}{lll}5.4 & \text { Reflectie } & 29\end{array}$

$\begin{array}{llr}6 & \text { Toegankelijkheid } & 30\end{array}$

$\begin{array}{lll}6.1 & \text { Inleiding } & 30\end{array}$

$\begin{array}{lll}6.2 & \text { Buurtscore } & 30\end{array}$

6.3 Knooppuntscore openbaar vervoer $\quad 32$

$\begin{array}{lll}6.4 & \text { Reflectie } & 32\end{array}$

$\begin{array}{llr}7 & \text { Levendigheid } & 34\end{array}$

$\begin{array}{lll}7.1 & \text { Inleiding } & 34\end{array}$

$\begin{array}{lll}7.2 & \text { Buurtscore } & 34\end{array}$

$\begin{array}{lll}7.3 & \text { Knooppuntscore openbaar vervoer } & 35\end{array}$

$\begin{array}{lll}7.4 & \text { Reflectie } & 36\end{array}$ 
$\begin{array}{lll}8.1 & \text { Inleiding } & 37\end{array}$

$\begin{array}{lll}8.2 & \text { Buurtscore } & 37\end{array}$

8.3 Knooppuntscore openbaar vervoer 38

8.4 Reflectie 38

$9 \quad$ Veiligheid

39

$\begin{array}{lll}9.1 & \text { Inleiding } & 39\end{array}$

$\begin{array}{lll}9.2 & \text { Buurtscore } & 40\end{array}$

9.3 Knooppuntscore openbaar vervoer $\quad 41$

$\begin{array}{lll}9.4 & \text { Reflectie } & 42\end{array}$

10

$\begin{array}{ll}\text { Aantrekkelijkheid } & 43\end{array}$

$\begin{array}{lll}10.1 & \text { Inleiding } & 43\end{array}$

$\begin{array}{lll}10.2 & \text { Buurtscore } & 44\end{array}$

10.3 Knooppuntscore openbaar vervoer $\quad 46$

$\begin{array}{lll}10.4 & \text { Reflectie } & 47\end{array}$

$\begin{array}{llr}11 & \text { Bewegwijzering } & 48\end{array}$

11.1 Inleiding $\quad 48$

$\begin{array}{lll}11.2 & \text { Buurtscore } & 48\end{array}$

$\begin{array}{lll}11.3 & \text { Knooppuntscore openbaar vervoer } & 49\end{array}$

$\begin{array}{lll}11.4 & \text { Reflectie } & 49\end{array}$

12 Loopscore $\quad 50$

$\begin{array}{lll}12.1 & \text { Inleiding } & 50\end{array}$

12.2 Loopscore per gemeente $\quad 50$

12.3 Loopscore per Ov-knooppunt $\quad 52$

12.4 Handelingsperspectieven $\quad 55$

$\begin{array}{lll}12.5 & \text { Reflectie } & 58\end{array}$

13 Conclusies en aanbevelingen $r 59$

$\begin{array}{lll}13.1 & \text { Conclusies bij de data } & 59\end{array}$

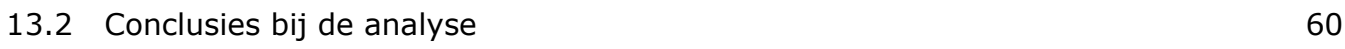

$\begin{array}{ll}13.3 & \text { Aanbevelingen }\end{array}$

$\begin{array}{ll}\text { Literatuur } & 64\end{array}$

$\begin{array}{lll}\text { Bijlage } 1 & \text { Overzicht indicatoren } & 67\end{array}$

$\begin{array}{lll}\text { Bijlage } 2 \text { Ov-Knooppunten } & 70\end{array}$

$\begin{array}{lll}\text { Bijlage } 3 & \text { Berekening en normen } & 71\end{array}$ 


\section{Verantwoording}

Rapport: 3101

Projectnummer: 5200046223

Wageningen Environmental Research (WENR) hecht grote waarde aan de kwaliteit van zijn eindproducten. Een review van de rapporten op wetenschappelijke kwaliteit door een referent maakt standaard onderdeel uit van ons kwaliteitsbeleid.

Akkoord Referent die het rapport heeft beoordeeld,

functie: $\quad$ senior onderzoeker

naam: Ir. J.H. Spijker

datum: 16 juli 2021

Akkoord teamleider voor de inhoud,

naam: C. van As

datum: 19 juli 2021 


\section{Samenvatting}

Is het mogelijk om op basis van kwaliteitsindicatoren de beloopbaarheid van buurten en ovknooppunten te meten met data via een Geografische Informatie Systeem (GIS)? Deze vraag is aan Wageningen Environmental Research (WENR) gesteld door de provincie Utrecht en het ministerie van Infrastructuur en Water. Een betere beloopbaarheid draagt namelijk bij aan aantrekkelijker steden en dorpen en bevordert voor inwoners en toeristen de verblijfskwaliteit, waardoor er meer sociaal contact en sociale veiligheid in de openbare ruimte kunnen zijn. Een betere beloopbaarheid heeft tevens invloed op de fysieke, sociale en mentale gezondheid van mensen. Daarnaast draagt een betere beloopbaarheid bij aan een klimaatbestendige inrichting van de openbare ruimte.

Op basis van (inter)nationaal literatuuronderzoek zijn 160 indicatoren gevonden die iets zeggen over de kwaliteit van een loopmogelijkheid. Een loopmogelijkheid is gedefinieerd als een voetpad, of een fietspad als er geen voetpad aanwezig is, of een rijbaan als er geen fiets- of voetpad aanwezig is. De 160 indicatoren zijn onderverdeeld in een lijst met 9 hoofdindicatoren (tussen haakjes het aantal indicatoren): Infrastructuur (11), Omgevingskwaliteit (8), Directheid van voorzieningen (9), Toegankelijkheid (32), Levendigheid (12), Allure (5), Veiligheid (23), Aantrekkelijkheid (54) en Bewegwijzering (6). Deze grote hoeveelheid indicatoren geeft aan hoe complex een goede beloopbaarheid is. Het gaat om zowel fysieke als sociale indicatoren, van detailniveau (als verlichting in een tunnel) tot macroniveau (als luchtkwaliteit). Beleidsmedewerkers van overheden en andere betrokkenen kunnen de lijst gebruiken om een aantal indicatoren te selecteren die passen bij hun beleidsopgave of doel, voor een handmatige schouw van voetpaden, maar ook om een loopscore automatisch te laten berekenen. Van $73 \%$ van de indicatoren zijn namelijk GIS-data beschikbaar. De GIS-data zijn afkomstig van de Basisregistratie Grootschalige Topografie (BGT), Bestand Bodemgebruik (BBG), Openstreetmap, Basisregistratie Adressen en Gebouwen (BAG), data van het RIVM, provincie Utrecht, WENR en andere instituten.

Deze pilotstudie heeft 103 indicatoren (64\%) geoperationaliseerd voor 38 ov-knooppunten (waarvan 28 treinstations en 10 bushaltes) die gekoppeld zijn aan 151 buurten in 19 gemeenten in de provincie Utrecht. De ontwikkelde loopscore is een kwaliteitsmaat voor de gebruikswaarde (het gemak) en belevingswaarde (aantrekkelijkheid) waarmee over een loopmogelijkheid gelopen kan worden. De loopscore is uitgedrukt in een z-score waarmee onvergelijkbare meeteenheden toch onderling te vergelijken zijn. De z-score geeft aan hoeveel standaarddeviaties een score van het gemiddelde af zit en kan dus positief (beter) als negatief (minder goed) zijn. Er is een z-score ontwikkeld voor de ovknooppunten waarbij een score van een ov-knooppunt wordt vergeleken met de scores van alle ovknooppunten in de provincie. En er is een z-score voor gemeenten waarbij de score van een loopmogelijkheid wordt vergeleken met de scores van alle loopmogelijkheden in diezelfde gemeente.

\section{De data}

De hoofdconclusie is dat de ontwikkelde loopscore een redelijke indicatie geeft van de kwaliteit van een loopmogelijkheid. Maar maatwerk blijft nodig, met name door het ontbreken van data, onder andere op detailniveau. Ontbrekende indicatoren zijn vaak ook sociaal van aard. De indicatie 'redelijk' komt omdat bij de beoordeling van de ingevulde data blijkt dat:

- de data van de hoofdindicatoren Begrijpelijke Infrastructuur, Omgevingskwaliteit, Directheid van voorzieningen, Allure en Aantrekkelijkheid goed zijn;

- de data van de hoofdindicatoren Toegankelijkheid en Levendigheid redelijk zijn;

- de data van de hoofdindicatoren Veiligheid en Bewegwijzering beperkt zijn;

- het nog niet duidelijk is of bepaalde indicatoren door (bepaalde) voetgangers belangrijker worden gevonden omdat er nog geen weging van de indicatoren is toegepast. Het kan dus zijn dat er data van indicatoren ontbreken, die voetgangers erg belangrijk vinden.

Het basisbestand bestaat uit de 63.225 loopmogelijkheden waarvoor een loopscore is berekend, zowel voor loopmogelijkheden in een buurt als rond een ov-knooppunt. De data van de loopmogelijkheden 
zijn afkomstig uit het BGT en bestaan uit polygonen en deze zijn niet altijd logisch opgebouwd, grillig van vorm, lengte en oppervlakte. De lengte van een loopmogelijkheid is in de analyse belangrijk. De GIS-techniek om de lengte van de polygonen te bepalen, is niet helemaal betrouwbaar bij grillige vormen van polygonen. Ook wordt de lengte soms niet tot aan de rand van een polygoon berekend. Daarom moet de lengte meer gezien worden als een indicatie.

De ontwikkelde loopscore geeft een eerste indicatie van de kwaliteit van loopmogelijkheden, ondanks de beschreven beperkingen. Beleidsmedewerkers van een gemeente krijgen hiermee inzicht waar en welke loopmogelijkheden en welke buurten in de gemeente goed dan wel minder goed scoren en welke indicatoren daar verantwoordelijk voor zijn, zodat gericht beleid mogelijk is.

\section{Analyse}

In totaal is er circa $3.400 \mathrm{~km}$ aan loopmogelijkheden in de 151 buurten. Daarvan is $68 \%$ een voetpad, $26 \%$ een rijbaan, $5 \%$ een fietspad en $2 \%$ een woonerf. Gemiddeld ontbreekt in circa $30 \%$ van de buurten en in $25 \%$ van een ov-knooppunt een voetpad en kan er niet exclusief op een voetpad gelopen worden, maar moet er op een fietspad, rijbaan of woonerf gelopen worden. Dit geldt in verhouding meer voor bushaltes dan voor treinstations. De gemiddelde breedte is $2,2 \mathrm{~m}$ indien alleen de voetpaden worden geselecteerd. Om voetpaden coronaproof te maken (minimaal 2,7 m breed), zou er minimaal $19 \mathrm{~km}$ aan voetpad moeten worden verbreed.

Uit de analyse blijkt dat van de totale lengte aan loopmogelijkheden $58 \%$ een positieve loopscore heeft. 11 van de 19 gemeenten hebben een positieve loopscore als geheel en 8 een negatieve. Op basis van de geselecteerde buurten heeft de gemeente Utrecht de hoogste loopscore en gemeente Houten de laagste. In de loopscore is de hoofdindicator Directheid van voorzieningen sterk bepalend, omdat er relatief veel data van beschikbaar zijn. De gemeente Utrecht dankt de hoge loopscore vooral door de zeer hoge score voor de hoofdindicator Directheid van voorzieningen. In deze gemeente hebben de onderzochte buurten relatief veel voorzieningen. In de 15 onderzochte buurten van de gemeente Houten scoort de hoofdindicator Aantrekkelijkheid minder goed. Uit nadere bestudering blijkt dat er in het databestand veel bomen niet opgenomen zijn die wel aanwezig zijn. Er zijn relatief weinig houtwallen, groene bermen en voortuinen in de geselecteerde buurten. Houten scoort hierdoor ook relatief laag op een groene uitstraling en er is enige kans op windhinder en relatief weinig beschutting.

Een meerderheid (58\%) van de ov-knooppunten heeft een negatieve loopscore. Bushaltes scoren beter op de meeste hoofdindicatoren dan treinstations. Treinstations scoren alleen beter op Directheid van voorzieningen en Bewegwijzering. Van alle ov-knooppunten scoort de Zamenhofdreef in de gemeente Utrecht het hoogst bij de bushaltes en Rijnsweerd-Noord in dezelfde gemeente het laagst.

In de provincie Utrecht is Utrecht Centraal Station het hoogst scorende ov-knooppunt en treinstation Breukelen het laagst. 96\% van de loopmogelijkheden rond Utrecht Centraal Station heeft een (zeer) hoge beloopbaarheid met de stationshal als hoogst scorende loopmogelijkheid. Treinstation Breukelen heeft met $24 \%$ de minste hoeveelheid voetpaden. Rond dit treinstation heeft $42 \%$ van de loopmogelijkheden een zeer lage beloopbaarheid.

\section{Handelingsperspectief}

De loopscore is met Excel gemaakt en via het Geografisch Informatiesysteem QGis zichtbaar gemaakt op kaart. Beleidsmedewerkers kunnen hiermee de loopscores per loopmogelijkheid zelf inzien en gerichte selectiemogelijkheden maken, bijvoorbeeld alle voetpaden smaller dan 1,5 m. De Excelfile kan gebruikt worden om te achterhalen in hoeverre een beleidsinitiatief effect heeft op de loopscore. Als voorbeeld is het initiatief van het Utrechts college genomen om het Ledig Erf in te richten als plein voor voetgangers en fietsers. Doorgaand autoverkeer langs de singel via het Ledig Erf is in dit voorstel niet meer mogelijk. Het Ledig Erf wordt autoluw. Daarnaast zijn verblijfskwaliteit, groen, veiligheid en fietsen belangrijke aandachtspunten. De volgende veranderingen zijn in de loopscoretool aangebracht: Omdat het geen doorgaand verkeer meer heeft, is de geluidbelasting naar beneden (65dB) bijgesteld. De modaliteit blijft onveranderd want er kan straks ook worden gefietst en het wordt weliswaar autoluw, maar auto's houden wel een rijbaan, waarop echter wel een verkeersdrempel is toegevoegd. De verblijfskwaliteit is in de tool vertaald naar het plaatsen van 3 bankjes en het wordt dus een plein. 
Er zijn 6 extra bomen ingevoerd om het groener te maken, evenals 5 bloembakken om het een meer groenere uitstraling te geven. Door het plaatsen van extra bomen wordt er ook koelte geschapen. De snelheid van het verkeer is naar beneden bijgesteld van 50 naar $30 \mathrm{~km}$ om aan de veiligheidswens te voldoen. De aanwezige verkeerseilanden zijn verwijderd (want niet meer nodig op een plein) en meer verlichting is toegevoegd. De huidige loopscore van 22,8 stijgt door de voorgestelde maatregelen zeer sterk, naar 408. Dit komt vooral door de hoofdindicator Aantrekkelijkheid.

Een ander voorbeeld is het zoeken naar de zwakste schakel bij de bereikbaarheid van een ov-halte. Ten noorden van treinstation Soest-Zuid ligt een woonwijk dat deels alleen het station kan bereiken via een looproute met een 'onveilig' voetpad. Dit voetpad ligt langs twee modaliteiten en is bovendien smal (tussen de 1 en 1,25 m breed) en minimaal $10 \mathrm{~m}$ lang. Daarbij staat er ook nog een verkeerspaal op het voetpad. Dit voetpad heeft een loopscore van $-4,9$ en is daarmee de zwakste schakel. Om het station voetgangersvriendelijker te maken, kan ervoor gekozen worden deze loopmogelijkheid te verbeteren.

\section{Aanbevelingen}

Het verdient aanbeveling om veel zorg te steken in het opbouwen van het basisbestand met loopmogelijkheden. Ook zou er onderzoek moeten worden gedaan naar de wijze waarop ook meer data van sociale indicatoren kunnen worden opgenomen. Te beginnen met de indicator Loopdrukte. Er kunnen beleidsmatig dan meer onderbouwde keuzes gemaakt worden om bepaalde loopmogelijkheden als eerste te verbeteren als daar veel gelopen wordt.

Het is te overwegen om de definitie van sommige indicatoren aan te passen of indicatoren te verwijderen die weinig voorkomen of alleen potentieel een obstakel kunnen zijn, zoals putten en bolders.

In het systeem scoren loopmogelijkheden zonder data op een indicator een 0 , omdat het niet duidelijk is hoeveel ervan aanwezig zijn en een 0 geeft dan een neutraal beeld. Maar er zijn ook loopmogelijkheden die wel voor die indicator een hoeveelheid hebben, maar veel minder dan overige loopmogelijkheden. De z-score is dan negatief en dus lager dan de 0. Dit is niet helemaal terecht en zou aangepast moeten worden.

Onderzoek naar de onderlinge weging van de indicatoren is van belang. Met name of deze weging per doelgroep verschillend is. De dan berekende loopscore van loopmogelijkheden in een buurt zou daarna ter validatie kunnen worden getoetst middels een enquête onder voetgangers en/of inwoners in die buurt.

De Excelfiles leveren een schat aan gegevens op waarmee diverse analyses gedaan kunnen worden, zoals een relatie tussen de woningprijzen en de loopscore in een buurt. Of de gezondheid van bewoners in een buurt, gerelateerd aan de loopscore en welke (hoofd)indicatoren daarbij het meest van belang zijn.

Provincie Utrecht kan beleidsmedewerkers van gemeenten met het bestand en de indicatoren ondersteunen met het formuleren van de verbeterkansen om buurten en ov-knooppunten voetgangersvriendelijker te maken. De indicatoren en data kunnen ook gebruikt worden bij een monitoringstool. De lijst met 160 indicatoren krijgt een meerwaarde door het te koppelen aan andere beleidsterreinen zoals het klimaatbeleid, waterbeleid, ruimtelijk beleid en gezondheidsbeleid.

Het is raadzaam te onderzoeken of de rekencapaciteit verkleind kan worden via slim programmeren, zodat het systeem gebruiksvriendelijker wordt.

Er zou een gebruiksvriendelijk dashboard gemaakt kunnen worden, bijvoorbeeld om eenvoudig ontbrekende data in te voeren of om effecten van berekeningen te laten zien. Dit zou een webbased versie kunnen zijn, bijvoorbeeld met behulp van digital twin-software of via een app. Dan zouden ook inwoners ingeschakeld kunnen worden om ontbrekende data van hun straat of buurt in te vullen. 


\section{$1 \quad$ Inleiding}

\subsection{Achtergrond}

Het ministerie van Infrastructuur en Water stelt dat het verbeteren van verkeersveiligheid belangrijk is, met een speciale aandacht voor fietsers en voetgangers. ${ }^{1}$ Dit geldt mede omdat Nederland wil voldoen aan de Sustainable Development Goals (SDG). Met name SDG 11.2 (access to safe, affordable, accessible and sustainable transport systems for all) en 11.7 (access to safe, inclusive and accessible, green and public spaces). Daarnaast draagt een betere beloopbaarheid bij aan een klimaatbestendige inrichting van de openbare ruimte. Lopen biedt ook oplossingen voor sociale opgaven als het levensloop bestendig inrichten van wijken en het bevorderen van gezondheid. Naar verwachting treedt de Omgevingswet begin 2022 in werking. Overheden werken hard aan het opstellen van omgevingsvisies en beleidsmedewerkers, verkeerskundigen, ruimtelijk ontwerpers, gezondheidsdeskundigen en lokale organisaties hebben behoeften aan concrete handvatten voor het benutten van de instrumenten die de Omgevingswet biedt voor het bevorderen van lopen. Volgens de landelijke GGD's moet het bevorderen van lopen en fietsen het centrale uitgangspunt zijn in beleid en ontwerp van de fysieke leefomgeving. "Door voor dagelijkse verplaatsingen naar werk, school en winkel, te fietsen en te lopen, kan iedereen voldoen aan de nationale beweegnorm. Voor langere afstanden kan dit in combinatie met ov. Actief vervoer heeft geen negatieve invloed op het klimaat. Niet parkeren op straat en minder auto's geven bovendien ruimte voor een aangename leefomgeving.

Het coalitieakkoord van de provincie Utrecht heeft als titel "Nieuwe energie voor Utrecht" en bevat zes inhoudelijke thema's: Gezonde economie, Levendige steden en dorpen, Sneller naar duurzame energie, Gezonde, veilige en duurzame mobiliteit, Mooie natuur en schoon water en een fijne en gezonde leefomgeving. Een betere beloopbaarheid van de openbare ruimte draagt bij aan de meeste thema's. In de omgevingsvisie van de provincie Utrecht staat dat met de komst van onder meer de elektrische fiets, ov-fietsen en 'Mobility-as-a-service'(MaaS)-concepten, de toenemende aandacht voor lopen en verbetering van de kwaliteit van reisinformatie in de gecombineerde ketenreizen steeds belangrijker worden. In stedelijk gebied neemt het belang van openbaar vervoer in combinatie met fietsgebruik en lopen toe, omdat deze wijzen van vervoer het best in staat zijn om de ruimtelijke groeiopgave te ondersteunen en beter passen bij een gezonde en duurzame levensstijl en de leefbaarheidskwaliteit in de stad.

In de visie staat ook dat lopen aantrekkelijk is voor korte verplaatsingen in het stedelijke gebied, bijvoorbeeld om de afstand tussen de ov-halte en de bestemming te overbruggen. De beloopbaarheid van routes vraagt daarom meer aandacht dan tot nu toe. In het uitvoeringsprogramma multimodale knooppunten 2019-2023 van de provincie Utrecht wordt dit verder uitgewerkt. In dit programma staat dat de kwaliteit van het knooppunt verhoogt naarmate het makkelijker wordt om er te komen. De kwaliteit hangt af van het aanbod van ov, de kwaliteit van de aanvoerroutes voor langzaam verkeer (niet-gemotoriseerd verkeer, zoals fietsers en voetgangers) en de beschikbaarheid van parkeer- en stallingsvoorzieningen. Een van de ambities bij het ontwikkelen van knooppunten is het realiseren van aantrekkelijke woon- en werklocaties die voor iedereen bereikbaar zijn. Het mobiliteitsprogramma noemt de volgende aspecten van kwaliteit en diversiteit van reisvoorzieningen die voor dit project van belang zijn:

- looproutes en bewegwijzering: toegankelijkheid, begrijpelijkheid, directheid. De kwaliteit, toegankelijkheid en bewegwijzering van looproutes moeten op alle knooppunten op orde zijn, passend bij het type knooppunt. Het is belangrijk om daar ook de nabijgelegen voorzieningen bij te betrekken. Een goede aansluiting op de omgeving is essentieel. Het aanleggen van uitnodigende wandelroutes en het wegnemen van obstakels in de looproutes dragen sterk bij aan het aantrekkelijk verbinden van het ov-knooppunt met de ruimtelijke omgeving.

\footnotetext{
${ }^{1}$ https://www.rijksoverheid.nl/actueel/nieuws/2018/04/26/minister-van-nieuwenhuizen-meer-europees-infrageld-voorveiligheid-fietsers-en-voetgangers
} 
- omgevingskwaliteit: veiligheid, aantrekkelijkheid, levendigheid, allure. Wachten, verblijven en ontmoeten zijn prettiger in een fijne omgeving. Op knooppunten is daarom de uitstraling van de omgeving (onder meer het stationsplein) van belang. Zeker bij nationale en regionale knopen mogen we hogere eisen stellen aan de uitstraling. In elk geval moeten knooppunten voldoen aan de basiseisen ten aanzien van 'schoon, heel en veilig'.

Deze twee kwaliteitscriteria zijn geconcretiseerd in een beleidskader. Daarmee wil de provincie de huidige inrichting van de knooppunten beoordelen. Dat leidt tot suggesties voor verbetering, zoals aantrekkelijk verknopen en verblijven. Deze suggesties zijn gericht op een betere bereikbaarheid van het knooppunt voor ov, fietser, voetganger en automobilist en op knooppunten die in elk geval schoon, heel en veilig zijn.

De provincie wil als kennismakelaar gemeenten ondersteunen met inventarisaties van de verbeterkansen voor de knooppunten om die aantrekkelijker of gebruikersvriendelijker te maken. De provincie zet in op het centraal onderzoeken van enkele thema's en de uitkomsten aan alle belanghebbenden beschikbaar te stellen voor toepassing in de eigen situatie. Het uitvoeren van een inventarisatie van kwaliteitsindicatoren van beloopbaarheid en het operationaliseren en meetbaar maken in dit project is daarvan een voorbeeld.

Meer dan dertig overheden, kennisinstellingen en maatschappelijke organisaties hebben zich verenigd in het platform Ruimte voor Lopen. Vanuit verschillende motieven willen zij meer plek en aandacht voor lopen. Binnen het platform Ruimte voor Lopen werken de partners samen aan projecten. Deze projecten geven concrete invulling aan de doelen van het platform en bestrijken verschillende thema's. Ze zijn gericht op het imago van lopen, een veilige, toegankelijke en aantrekkelijke loopomgeving en op lopen als integraal onderdeel van beleid. Een van de projecten is het inventariseren van kwaliteitsindicatoren van beloopbaarheid, het operationaliseren, het meten, waarderen en publiceren van de beloopbaarheid van wijken en buurten.

\subsection{Probleemstelling}

De provincie Utrecht en het ministerie van Infrastructuur en Water (I\&W) maken deel uit van het Platform Ruimte voor Lopen. Wageningen Environmental Research is als partner van het platform gevraagd om een deskundig onderzoek uit te voeren en antwoord te geven op de volgende onderzoeksvragen:

- Welke indicatoren zijn van belang om zicht te krijgen op de beloopbaarheid van buurten en ovknooppunten?

- Welke (GIS)-data zijn beschikbaar om de indicatoren te meten?

- Wat is de loopscore van buurten en ov-knooppunten op basis van de verzamelde data?

- Wat is de waarde van deze loopscore in het licht van het totaalaantal indicatoren?

- Wat kan er beleidsmatig gedaan worden om de loopscore te verhogen?

\subsection{Doelstelling}

Het doel van het project is inzicht te geven in hoeverre de beloopbaarheid van buurten en ovknooppunten is te meten met bestaande data. De toepassing is in een pilot ontwikkeld in de provincie Utrecht in een aantal buurten en ov-knooppunten. Na een positieve beoordeling zou de toepassing in andere buurten en ov-knooppunten uitgerold kunnen worden.

\subsection{Leeswijzer}

Hoofdstuk 2 behandelt de werkwijze om tot een loopscore te komen. In dit technische deel bespreken we op hoofdlijnen de keuzes die gemaakt zijn. Een meer uitvoerige beschrijving is in bijlage 3 beschreven. 
Hoofdstuk 3 tot en met 11 beschrijven de resultaten per hoofdindicator. De resultaten zijn zowel per ov-knooppunt weergegeven als per buurt waar het ov-knooppunt in ligt. Omdat dit een pilotstudie is, hebben we extra aandacht voor de meer extreme situaties om te beoordelen of dat juist is. Dit doen we door de hoogste en laagste score te bespreken en te vergelijken met de werkelijke situatie. De werkelijke situatie bekijken we via GoogleEarth en Street view, rekening houdend dat Street view soms gedateerd is. In deze hoofdstukken staat ook een reflectie op de behaalde resultaten.

De uiteindelijke loopscore per buurt en per ov-knooppunt is beschreven in hoofdstuk 12, waar ook met een voorbeeld beschreven is hoe beleidsmatig de data te gebruiken zijn om de openbare ruimte voor lopen te verbeteren. Het rapport wordt afgesloten met conclusies en aanbevelingen.
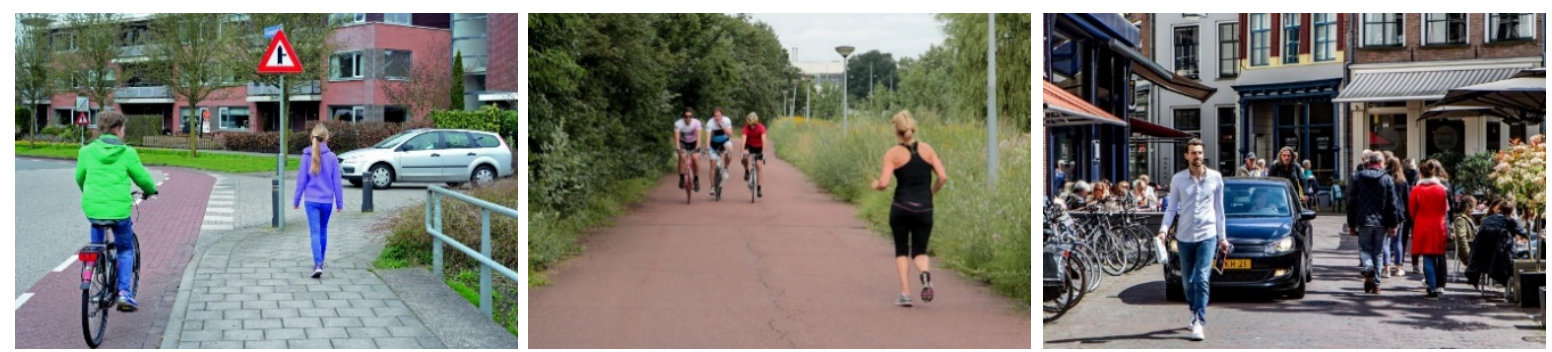

Diverse loopmogelijkheden (Bron: VVN.nl, Cobouw.nl, stentor.nI) 


\section{Werkwijze}

\section{$2.1 \quad$ Inleiding}

In dit technische hoofdstuk is op hoofdlijnen de werkwijze gerapporteerd en worden de keuzes besproken die gemaakt zijn. Een meer uitvoerige beschrijving van de werkwijze staat in bijlage 3 .

\subsection{Indicatoren, ov-knooppunten en buurten}

\subsubsection{Indicatoren}

$\mathrm{Er}$ is een (inter)nationaal literatuuronderzoek uitgevoerd om indicatoren te selecteren die van belang zijn bij het lopen. Uit elke publicatie zijn de gebruikte indicatoren in een lijst gezet. Na 35 publicaties was er de indruk dat er geen nieuwe indicatoren werden genoemd en dat de indicatoren die in de lijst waren opgenomen de belangrijkste zijn. De lijst betreft 160 indicatoren (zie bijlage 1). De 160 indicatoren zijn vervolgens verdeeld naar de indeling in hoofdindicatoren zoals de provincie Utrecht die hanteert. Deze negen hoofdindicatoren zijn (met tussen haakjes het aantal indicatoren):

- Begrijpelijke Infrastructuur (11)

- Omgevingskwaliteit (8)

- Directheid van voorzieningen (9)

- Toegankelijkheid (32)

- Levendigheid (12)

- Allure (5)

- Veiligheid (23)

- Aantrekkelijkheid (54)

- Bewegwijzering (6)

Veruit de meeste indicatoren hebben betrekking op de aantrekkelijkheid om te lopen, gevolgd door de toegankelijkheid en veiligheid (zowel fysieke als sociale).

Vervolgens is onderzocht in hoeverre er GIS-data aanwezig zijn om de indicatoren te kunnen meten. Daarbij is gekeken naar landelijk en provinciaal niveau. GIS-data op gemeentelijk niveau zijn niet meegenomen, omdat niet elke gemeente data verzameld en/of data van verschillende indicatoren verzameld, waardoor vergelijking niet mogelijk is. Daarnaast is gekeken of de data op voetpad-niveau aanwezig was of berekend kon worden. Data die alleen op wijk- of gemeenteniveau of voor het buitengebied beschikbaar zijn, zijn voor wegdelen in buurten niet onderscheidend. Deze zijn voorlopig nog niet meegenomen in de analyse. Bij 14 indicatoren was dit het geval. Van 43 indicatoren zijn geen of niet direct GIS-data gevonden. Uiteindelijk zijn er 103 indicatoren overgebleven om de beloopbaarheid te meten. Dit is $64 \%$ van het totaal. Daarmee kan een redelijke indicatie van de beloopbarheid worden gegeven. Het blijft een indicatie, omdat niet alle indicatoren dus meegenomen zijn en het onderlinge belang nog niet meegewogen is. Sommige indicatoren zullen belangrijker gevonden worden dan andere. Dit laatste vraagt om een apart onderzoek onder diverse doelgroepen. 
Tabel 1

Mate vaan aanwezigheid GIS-data per hoofdindicator.

\begin{tabular}{|c|c|c|c|c|c|}
\hline Hoofdindicator & Straatdata & Andere Data & Geen data & Totaal & Percentage straatdata \\
\hline Begrijpelijke Infrastructuur & 10 & 1 & 0 & 11 & 91 \\
\hline Omgevingskwaliteit & 5 & 3 & 0 & 8 & 63 \\
\hline Toegankelijkheid & 18 & 5 & 9 & 32 & 56 \\
\hline Levendigheid & 7 & 0 & 5 & 12 & 58 \\
\hline Veiligheid & 12 & 1 & 10 & 23 & 52 \\
\hline Aantrekkelijkheid & 35 & 2 & 18 & 55 & 64 \\
\hline Bewegwijzering & 4 & 1 & 0 & 5 & 80 \\
\hline Totaal & 103 & 14 & 43 & 160 & 64 \\
\hline
\end{tabular}

Tabel 1 geeft een overzicht van hoeveel indicatoren GIS-data opgenomen zijn per hoofdindicator. Uit deze tabel blijkt dat bij alle hoofdindicatoren er meer dan 50\% data beschikbaar zijn van de bijbehorende indicatoren. Bij de hoofdindicator Allure zijn zelfs van alle indicatoren data aanwezig. In verhouding zijn er van de hoofdindicatoren Veiligheid, Toegankelijkheid en Levendigheid minder data gevonden.

\subsubsection{Ov-knooppunten en buurten}

De provincie Utrecht heeft een lijst met Openbaar Vervoer (ov) knooppunten geleverd waar zij de beloopbaarheid van wil weten. Deze lijst bevat 28 treinstations en 10 bushaltes in de provincie (zie figuur 2 en bijlage 2).

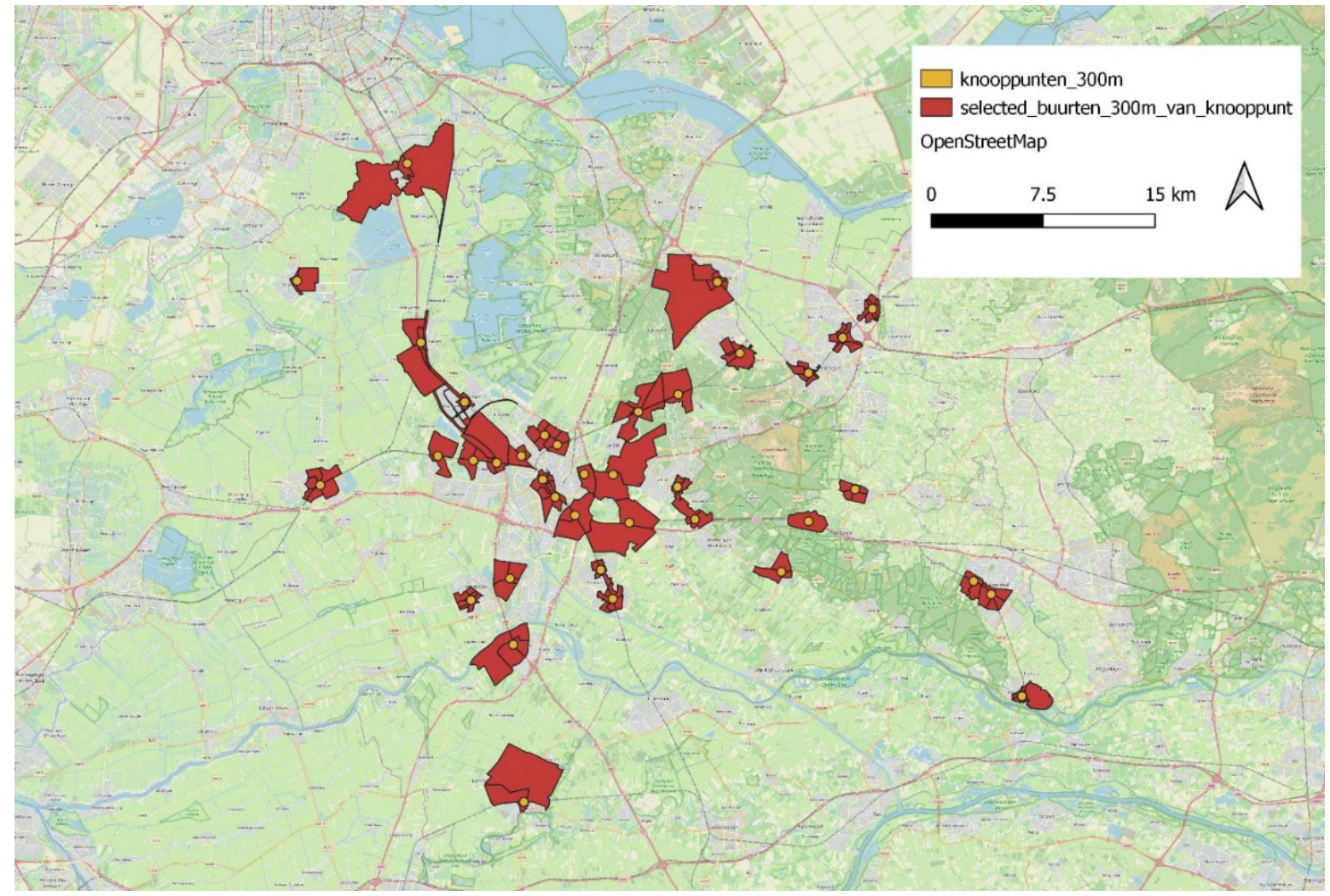

Figuur 1 Ligging ov-knooppunten en buurten.

De infrastructuur is geselecteerd in een straal van $300 \mathrm{~m}$ rond een knooppunt, omdat mensen niet verder dan tussen de 200 en 400 m van een bushalte willen lopen (Molster \& Schuit, 2021). Omdat er de wens is om niet alleen van ov-knooppunten de beloopbaarheid te meten maar ook van buurten, zijn ook de bijbehorende buurten geselecteerd met de daarin liggende infrastructuur. Dit betreft in 
totaal 151 buurten in 19 gemeenten. Voor treinstations zijn mensen bereid een stuk verder te lopen (Molster \& Schuit, 2021; Sweco, 2021)) en omdat de infrastructuur ook in deze buurten zijn geselecteerd, kan daaraan meestal ook worden voldaan. Sommige ov-knooppunten liggen aan de rand van een buurt, maar wel binnen $300 \mathrm{~m}$ van de grens van die buurt. Daardoor is een aangrenzende buurt niet meegenomen in de selectie. Inwoners van sommige woonwijken zoals Breukelen en Driebergen kunnen het geselecteerde ov-knooppunt niet lopend bereiken binnen $300 \mathrm{~m}$. De loopscore is zowel voor een ov-knooppunt als voor een buurt berekend.

In de gemeente Utrecht zijn de meeste buurten en ov-knooppunten geselecteerd (tabel 2), gevolgd door Amersfoort en Houten. Gemeente Bunnik heeft met twee het minst aantal buurten. Elke gemeente heeft ten minste twee buurten om mee te vergelijken.

Tabel 2 Aantal buurten en ov-knooppunten per gemeente.

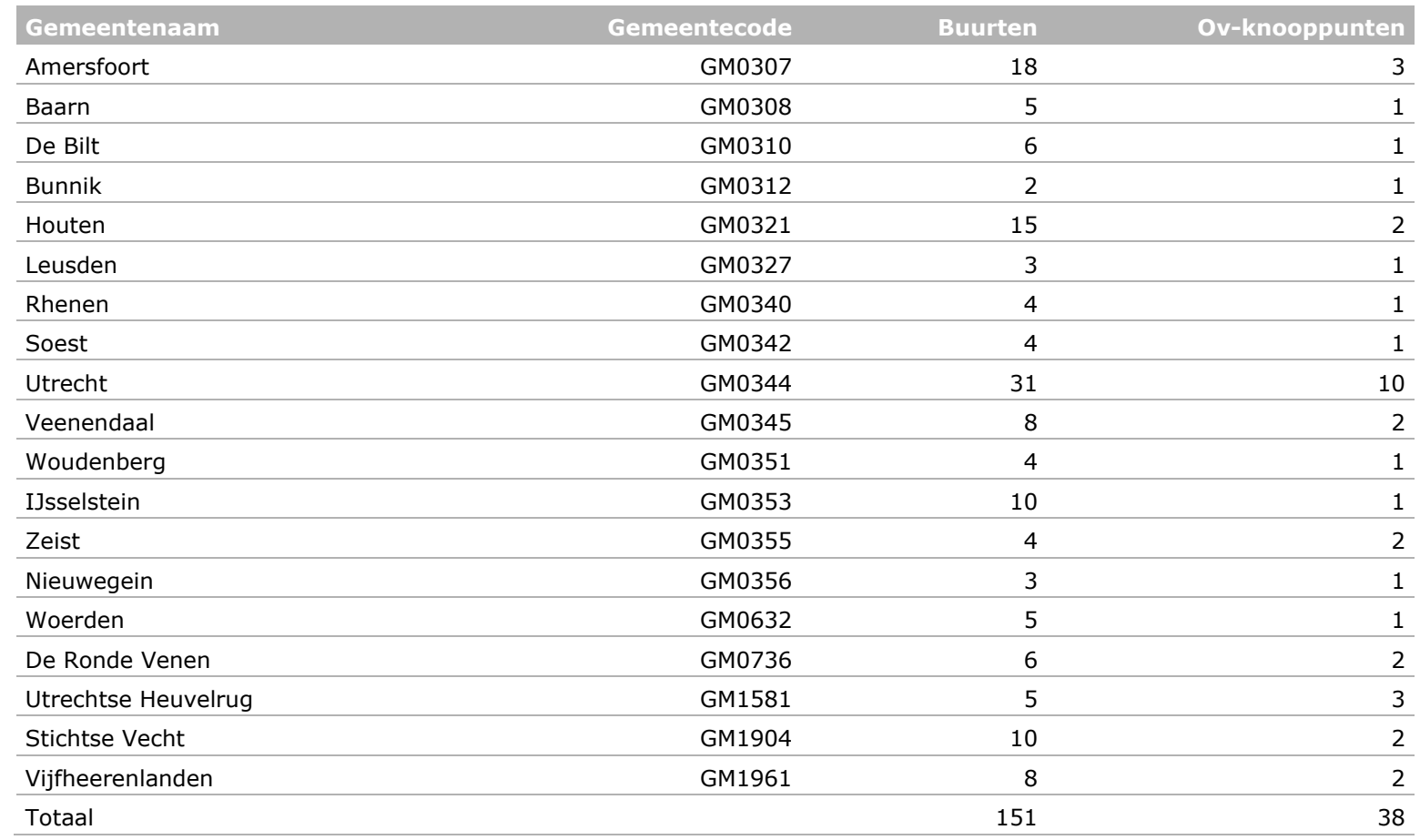

\subsection{GIS-data}

De data van de geoperationaliseerde indicatoren zijn allemaal gebaseerd op open-source data. De data komen van de Basisregistratie Grootschalige Topografie (BGT), Bestand Bodemgebruik (BBG), Openstreetmap, Basisregistratie Adressen en Gebouwen (BAG), data van het RIVM, provincie Utrecht, WENR en andere instituten. Het BGT bevat een verplicht deel van levering door een databeheerder en een niet verplicht deel (niet-BGT). Een flink aantal indicatoren valt onder het niet-verplichte deel en de data zijn dan ook niet in alle buurten aanwezig en/of volledig, zoals de indicator bomen. In dergelijke gevallen is gezocht, waar mogelijk, naar andere open source databronnen. Voor bomen is bij WENR een bomenregistratiebestand aanwezig die daarom is gebruikt.

Uitgangspunt is om op een zo laag mogelijk schaalniveau de data te verzamelen. Voor onderzoeksdoeleinden is vaak een wijk of buurtniveau voldoende. Overheden willen liever naar een nog lager schaalniveau om heel gericht beleid te kunnen voeren. Ze willen bijvoorbeeld weten hoe aantrekkelijk de looproute tussen het centrum en het treinstation is. Dit betekent concreet een voetpad. Voetpaden zijn een verplicht deel in de BGT, evenals voetgangersgebied en voetpad-op-trap. Maar als er geen voetpad aanwezig is, kan er toch gelopen worden, bijvoorbeeld op een fietspad of op een rijbaan. Deze wegdelen zijn dus ook geselecteerd, evenals andere loopmogelijkheden, zoals woonerven, inritten en ruiterpaden. In de BGT zijn dit allemaal vlakken (polygonen). Het programma 
QGis is gebruikt voor de GIS-bewerkingen. De polygonen leveren GIS-matig de nodige problemen, want ze zijn niet eenvormig. Er zitten rechthoeken bij, maar ook heel grillige vormen (figuur 2). Er zijn heel kleine polygonen, maar ook erg lange. Ook stopt een voetpad niet bij een kruising, maar gaat soms 'de bocht om'. De voetpaden zijn dus niet logisch opgebouwd. Een netwerkanalyse rond ovknooppunten was dan ook niet mogelijk binnen het tijdsbestek van dit project.

Snelwegen en provinciale wegen zijn niet geselecteerd omdat het daar (meestal) verboden is om te lopen. In totaal zijn er in eerste instantie 81.763 wegdelen in deze pilot geselecteerd waarvoor data verzameld zijn.

Bij deze selectie zijn er te veel wegdelen, want het komt veelvuldig voor dat er een rijbaan is met aan beide kanten een voetpad. In eerste instantie zijn dergelijke rijbanen dus ook geselecteerd, terwijl dat niet hoeft omdat er voetpaden zijn.

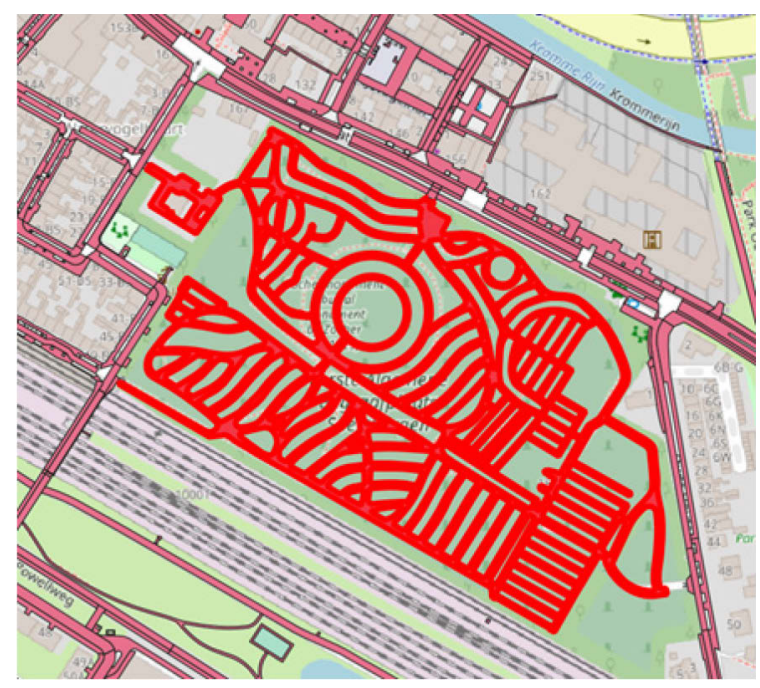

Figuur 2 Rood omlijnd is 1 wegdeel.

Dit probleem is deels opgelost door alleen die fietspaden en rijbanen te selecteren die grenzen ${ }^{2}$ aan een woongebied die als vlakken zijn opgenomen in de BGT. Desalniettemin zijn er toch rijbanen geselecteerd waar voetpaden naast liggen, omdat een klein deel van een rijbaan grenst aan een woongebied-vlak. Het is in het tijdsbestek van dit project niet gelukt om deze rijbanen automatisch te verwijderen. Niet alle fietspaden en rijbanen grenzen aan een woongebied. Vandaar dat ook fietspaden geselecteerd zijn die in een park of plantsoen en op $5 \mathrm{~m}$ afstand van een voetpad liggen. Ten slotte zijn er ook fietspaden en rijbanen geselecteerd die niet grenzen aan een woongebied of park of plantsoen, maar wel op $5 \mathrm{~m}$ afstand liggen van een voetpad. Ook dit is niet helemaal correct gegaan, want er zijn wegdelen uitgevallen die wel opgenomen hadden moeten worden. Dit is vaak het geval bij T-kruisingen tussen fietspad/rijbaan en voetpad. Deze fietspaden/rijbanen vallen in de selectie weg.

Door al deze selecties zijn sommige wegdelen soms ook dubbel geselecteerd. Deze dubbellingen zijn via Excel verwijderd. Circa 900 wegdelen hebben een oppervlakte kleiner dan $1 \mathrm{~m}^{2}$. Deze zijn niet meegenomen in de berekening. Uiteindelijk is er een bestand overgebleven van 63.225 wegdelen.

\subsection{Loopscore}

Aangezien de meeteenheden van de verschillende indicatoren verschillend zijn, is het onwenselijk om ze gewoon op te tellen. Sommige meeteenheden zijn een percentage, andere een index, een $d B(A)$ of een ja/nee-situatie. Om onvergelijkbare meeteenheden te vergelijken, is de z-score per wegdeel

\footnotetext{
2 De syntax 0,1 $\mathrm{m}$ van het dichtstbijzijnde vlak is gebruikt om deze wegdelen te selecteren.
} 
gebruikt. Met de z-score is het mogelijk om scores op verschillende indicatoren met elkaar te vergelijken, omdat de meeteenheid van een indicator er op deze manier niet meer toe doet. De z-score geeft aan hoeveel standaarddeviaties een score van het gemiddelde af zit.

$\mathrm{Z}=(\mathrm{X}-\mu) / \sigma$ waarbij:

$Z=z$-score;

$\mathrm{X}=$ score van loopmogelijkheid op een indicator;

$\mu=$ gemiddelde per ruimtelijke eenheid (gemeente of provincie) van loopmogelijkheden op een indicator;

$\sigma=$ standaarddeviatie per ruimtelijke eenheid (gemeente of provincie) van loopmogelijkheden op een indicator.

Omdat een z-score met gemiddelden werkt, moet bepaald worden waarop die gemiddelden betrekking hebben. De verwachting is dat gemeenten het systeem zullen gaan gebruiken en daarom zijn van elke gemeente de gemiddelde scores op de indicatoren berekend. De buurtscore is bepaald door de afzonderlijke z-scores van de indicatoren van een wegdeel op te tellen voor de wegdelen die in een buurt liggen. Deze z-score is gedeeld door het aantal wegdelen per buurt, aangezien het aantal wegdelen per buurt verschillend is. Een gemeente krijgt hiermee inzicht welke wegdelen goed dan wel minder goed scoren en welke buurten gemiddeld beter dan wel minder goed scoren. Hiervoor is gekozen, omdat het voor een gemeente naar verwachting minder interessant is om een wegdeel te vergelijken met wegdelen in andere gemeenten in de provincie.

Voor elk wegdeel zijn per ov-knooppunt ook het gemiddelde en de z-score berekend. Ditmaal wordt de score van een ov-knooppunt vergeleken met de scores van ov-knooppunten in de hele provincie Utrecht. Het resultaat is dat inzicht wordt verkregen of een ov-knooppunt ten opzichte van andere ovknooppunten in de provincie Utrecht goed dan wel minder goed scoort.

Een score hoger dan 0 voor een indicator betekent dat het wegdeel beter scoort dan gemiddeld. Een score lager dan 0 voor een indicator betekent dat het wegdeel slechter scoort dan gemiddeld. Nadeel zijn scores die voor een gemeente hetzelfde zijn. Dan krijgt elk wegdeel een standaarddeviatie van 0 en weet je niet of dat positief dan wel negatief is. De z-score is een relatieve vergelijking. Het kan dus zijn dat een loopmogelijkheid voor een indicator binnen een gemeente slecht scoort, maar dat de gemeente als geheel zeer goed scoort op die indicator. Om hier zicht op te houden, is ook het gemiddelde van een gemeente ten opzichte van andere gemeenten berekend voor die indicator. De oorspronkelijk scores zijn ook gerapporteerd.

De z-score van een hoofdindicator is de som van de afzonderlijke z-scores van de indicatoren behorend bij die hoofdindicator. De loopscore is vervolgens de som van alle hoofdindicatoren.

Om in de toekomst een weging toe te passen naar belangrijkheid, zijn in de Excelfile ook kolommen gereserveerd om deze weging in op te nemen. Deze zijn vooralsnog allemaal op 1 gezet.

\subsection{Gebruiksvriendelijkheid}

Dit rapport beschrijft een deel van de resultaten. Alle resultaten staan in separate Excelfiles. Dit is in de vorm van een Pivot-tabel. In een Pivot-tabel is het eenvoudig bepaalde onderdelen te selecteren.

Door de vele data is deze Excelfile nog niet erg gebruiksvriendelijk. Het is meer op te vatten als het motorblok van een auto. Maar nog niet de gehele auto zelf. Alhoewel de Pivot-tabel gebruikt kan worden om te selecteren, is er nog geen gebruiksvriendelijk invoerscherm gemaakt, bijvoorbeeld om ontbrekende data in te voeren. Een dergelijk systeem moet apart ontwikkeld worden met toekomstige gebruikers en vervolgens meerdere malen getest worden. Dit vraagt om een apart project. De bij dit project behorende separate Excelfile levert wel de algoritmen. Het vraagt veel rekengeheugen en schijfruimte, omdat er veel vergelijking gemaakt worden in Excel. Dit betekent dat er niet één bestand kan worden gemaakt, want de laptop kan dat niet aan. Er is voor gekozen om het bestand op te 
knippen in afzonderlijke delen waarbij de hoofdindicatoren leidend zijn. Dit levert voor het gemeentebestand vijf aparte bestanden op waarbij er bij de loopscore intern naar de andere bestanden verwezen wordt. Bij de ov-knooppunten zijn drie aparte bestanden met dezelfde interne werking. Dit maakt het systeem niet erg gebruiksvriendelijk.

De Excelfile begint met een invoerblad "Basis". In deze basis zijn alle afzonderlijke wegdelen als record opgenomen (dus 63.225 records) met hun administratieve gegevens ( 17 kolommen) en tot welke buurt, wijk, gemeente of ov-knooppunt het behoort, en de score op de diverse indicatoren, waarbij ook in de kolommen indicatoren staan waar nog geen data van zijn (dus 160). Dit levert ruim 11 miljoen cellen op en dat is erg groot voor Excel. Dit invoerblad moet gebruikt worden als een waarde van een indicator ontbreekt of als een waarde veranderd moet worden, omdat het ingevoerde onjuist is of veranderd wordt als gevolg van een scenario.

Vervolgens is er een blad "L_basis". In dit blad worden de waarden van de indicatoren gerelateerd aan de lengte van een wegdeel indien dat nodig is. Het maakt namelijk voor een kwaliteitsmeting uit of er 5 bomen op $50 \mathrm{~m}$ voetpad staan of 5 bomen op $500 \mathrm{~m}$. De waarde van een indicator wordt gedeeld door de lengte van een loopmogelijkheid en vervolgens vermenigvuldigd met 100 . Dit wordt niet bij alle indicatoren gedaan, aangezien een deel al een percentage is. Percentages komen vooral bij de indicatoren van de hoofdindicator Omgevingskwaliteit voor.

Vervolgens zijn er de bladen G_gem, G_SD en Z_Gmt. Deze zijn nodig om de z-score te berekenen van de afzonderlijke indicatoren per wegdeel. G_gem staat voor Gemeente_gemiddelde en geeft de gemiddelde waarde weer van een indicator van een wegdeel per gemeente. G_SD staat voor Gemeente_ Standaard deviatie (SD) en geeft de SD van een indicator van een wegdeel per gemeente.

De bladen beginnende met $Z_{\text {_ }}$ geven de uiteindelijke z-scores weer. In het blad Z_Gmt zijn de gemiddelde scores van indicatoren van gemeenten berekend om gemeenten onderling te kunnen vergelijken. Elke hoofdindicator heeft vervolgens een eigen blad met de daarbij horende z-scores van de indicatoren.

In een aparte file staat de loopscore van de loopmogelijkheden vermeld, met een interne WENRverwijzing. Door deze interne verwijzing zijn de files niet te lezen bij andere instituten. Vandaar dat ook de kale waarden (zonder verwijzing) zijn opgenomen.

Indien een waarde moet worden veranderd, kan dat dus in het blad "Basis". Wel moet dan in alle volgende bladen op "refresh" gedrukt worden om de algoritmen te laten uitvoeren in de betreffende bladen om het effect te kunnen zien. Dit is nog geen gebruiksvriendelijke handeling. Ook dit kan in apart systeem beter worden vormgegeven. 


\section{Infrastructuur}

\section{$3.1 \quad$ Inleiding}

In totaal zijn er elf indicatoren om een beeld te geven van de infrastructuur. Er zijn van tien indicatoren data gevonden. De indicator Dichtheid aan kruispunten is vooralsnog niet berekend, omdat de wegdelen geen logische opbouw hebben en dus erg veel GIS-technieken vragen om de kruispunten te kunnen berekenen. De diverse type wegdelen zijn als indicator Loopmogelijkheden opgenomen. Daarnaast is er de indicator Mobiliteitsscheiding. De indicator Loopmogelijkheid geeft de mate van exclusiviteit aan voor voetgangers. Hoe rustiger men op een loopmogelijkheid kan lopen, dus zonder rekening te houden met andere weggebruikers, hoe hoger de score. Een voetpad wordt soms onderbroken door een inrit. Een inrit is een aparte categorie in de BGT. Deze inritten zijn ook geselecteerd als loopmogelijkheid.

Modaliteitsscheiding geeft aan hoeveel modaliteiten koppelen aan een voetpad. Het geeft aan hoe 'rustig' het beeld is. Ligt er een fietspad naast het voetpad, dan is er één modaliteit. Ligt er daarnaast nog een rijbaan, dan zijn er twee modaliteiten. Hoe meer modaliteiten, hoe onrustiger het beeld is om te lopen en hoe onveiliger om bijvoorbeeld over te steken. Een hoge score op de indicator Modaliteitscheiding werkt dus negatief. Modaliteitsscheiding is dus alleen toegepast bij voetpaden, voetgangersgebied en voetpad-op-trap.

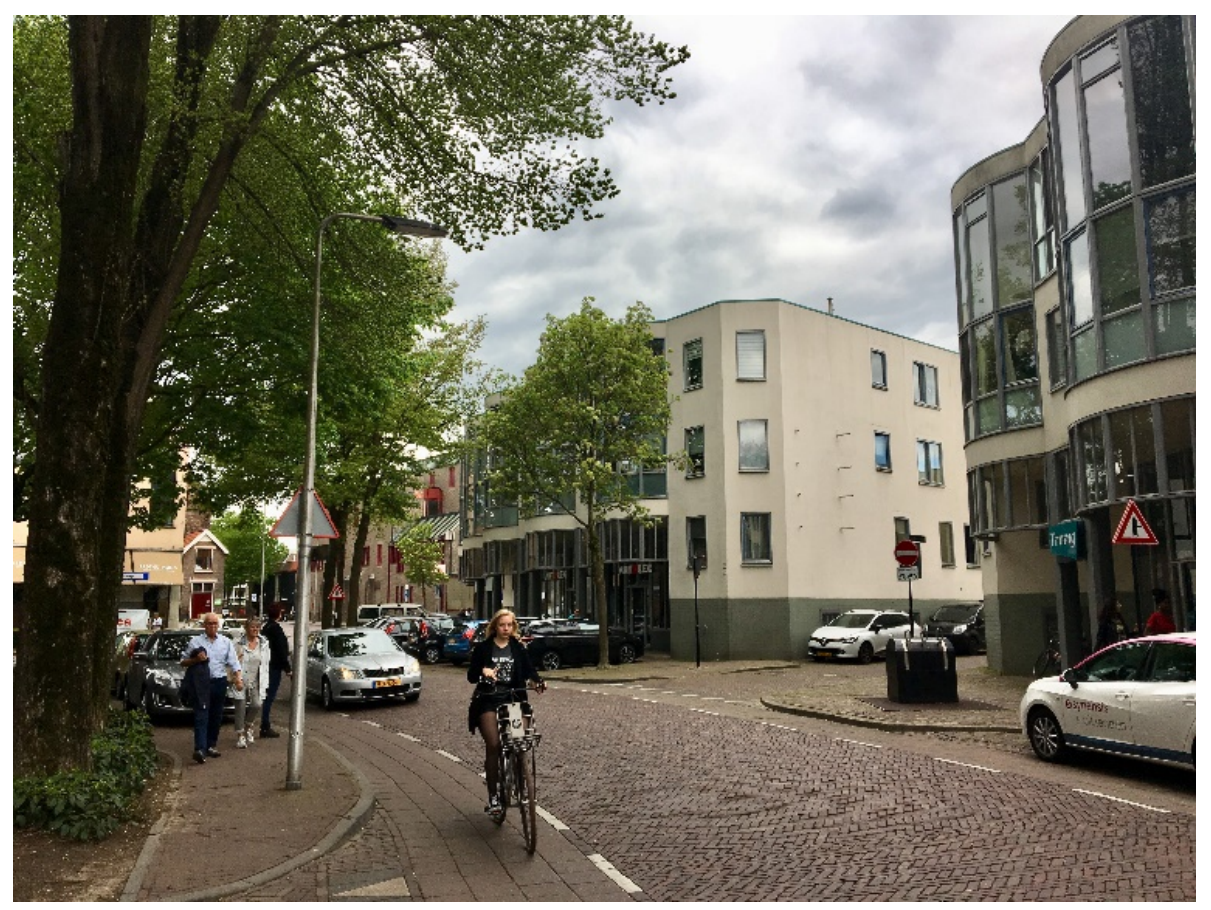

Foto 1 Naast het voetpad liggen twee modaliteiten, namelijk een fietspad en een rijbaan (Bron: verkeersnet.nI).

De wegdelen zijn verschillend in grootte; er zitten wegdelen in van $1 \mathrm{~m}$, maar ook van $150 \mathrm{~m}$ lang. Dit is tot uitdrukking gebracht door een methode te gebruiken die ook in de TOD-studie is toegepast. In dit geval is de lengte gedeeld door 100 en vervolgens vermenigvuldigd met de waarde van de indicator. De volledige lijst met resultaten is in een separate Excelfile te vinden. 


\subsection{Burtscore in de gemeenten}

In totaal is er circa $3.400 \mathrm{~km}$ aan loopmogelijkheden in de 151 buurten. Daarvan is $68 \%$ een voetpad $^{3}, 26 \%$ een rijbaan, $5 \%$ een fietspad en $2 \%$ een woonerf. Dus in circa $30 \%$ van alle buurten ontbreekt een voetpad en kan er niet exclusief op een voetpad gelopen worden, maar moet er op een fietspad, rijbaan of woonerf gelopen worden.

De buurt met de meeste loopmogelijkheden is Bunnik (BU03120000), rond het treinstation Bunnik met circa $94 \mathrm{~km}$. Buurt De Laak Oost in Amersfoort (BU03073100), rond treinstation Amersfoort Vathorst, heeft met 2,1 km de minste loopmogelijkheden.

Buurt Wagenwerkplaats in Amersfoort (BU03070503) rond treinstation Amersfoort Centraal heeft met $97 \%$ de meeste voetpaden van het totaal aan loopmogelijkheden $(5 \mathrm{~km})$ in deze buurt. Kanaalzone Noord Breukelen in Stichtse Vecht (BU19040214) heeft met 5\% de minste voetpaden en inritten. Polder Kortrijk (BU19040201) in Breukelen heeft 1\% aan voetpaden en 12\% aan inritten, maar heeft daarentegen wel een van de hoogste percentages (84\%) aan rijbanen van alle buurten. In deze buurt moet dus vaak op een rijbaan gelopen worden omdat een voetpad ontbreekt.

Vervolgens is de hoofdindicator Infrastructuur van buurten in een gemeente met elkaar vergeleken. Hoe hoger de waarde op de indicator Loopmogelijkheden (zoals een voetpad in een park), hoe hoger de score op deze indicator. Hoe hoger de waarde op indicator Modaliteitscheiding, hoe lager de score.

Het kan zijn dat een buurt een hoge score heeft voor infrastructuur, maar dat de gemeente waar de buurt in ligt als geheel slecht scoort ten opzichte van andere gemeenten. Dit is berekend door de gemeente met andere gemeenten in de provincie Utrecht te vergelijken via de z-score. Een buurt met een hoge score voor de hoofdindicator Infrastructuur in een slecht scorende gemeente, scoort dan relatief goed. Vandaar dat eerst beschreven wordt hoe een gemeente scoort ten opzichte van andere gemeenten in de provincie Utrecht.

De gemeente Woudenberg scoort met de z-score het hoogst op de hoofdindicator Infrastructuur (tabel 3) en de gemeente Baarn het laagst in vergelijking met andere gemeenten in de provincie. De gemeente Woudenberg scoort relatief hoog omdat ze gemiddeld het hoogst op de indicator Loopmogelijkheden scoort. De gemeente Vijfheerenlanden scoort het best op de indicator Modaliteitsscheiding.

Tabel 3 Gemiddelde score per indicator en z-score behorende bij infrastructuur per gemeente.

\begin{tabular}{|c|c|c|c|c|}
\hline Gemeentenaam & Gemeentecode & Loopmogelijkheden & Modaliteitsscheiding & Z-score \\
\hline Amersfoort & GM0307 & 1.89 & 0.71 & 0.65 \\
\hline Baarn & GM0308 & 1.61 & 1.33 & -2.64 \\
\hline Bunnik & GM0312 & 1.44 & 0.48 & 0.18 \\
\hline Houten & GM0321 & 1.48 & 0.48 & 0.28 \\
\hline Rhenen & GM0340 & 1.50 & 0.54 & 0.14 \\
\hline Soest & GM0342 & 1.58 & 0.95 & -1.20 \\
\hline Utrecht & GM0344 & 1.66 & 0.54 & 0.61 \\
\hline Veenendaal & GM0345 & 1.23 & 0.74 & -1.46 \\
\hline Woudenberg & GM0351 & 2.30 & 0.65 & 2.11 \\
\hline Nieuwegein & GM0356 & 1.30 & 0.47 & -0.19 \\
\hline Woerden & GM0632 & 1.82 & 0.45 & 1.44 \\
\hline De Ronde Venen & GM0736 & 1.48 & 0.50 & 0.21 \\
\hline Utrechtse Heuvelrug & GM1581 & 1.21 & 0.47 & -0.46 \\
\hline Stichtse Vecht & GM1904 & 1.03 & 0.43 & -0.87 \\
\hline Vijfheerenlanden & GM1961 & 1.41 & 0.32 & 0.69 \\
\hline
\end{tabular}

\footnotetext{
3 Inclusief voetgangersgebied, voetpad op trap en inritten.
} 
De z-score van de hoofdindicator Infrastructuur van buurten van de relatief hoger en lager scorende gemeenten is vervolgens weergegeven in tabel 4 waarbij een buurt is vergeleken met andere buurten in die gemeente. ${ }^{4}$ In tabel 4 zijn alleen de buurten met de hoogste en de laagste z-score weergegeven. Dit is gebaseerd op de som van de z-scores van alle loopmogelijkheden in die buurt. De gemiddelde z-score is genomen, aangezien per buurt het aantal loopmogelijkheden verschilt. De $z$-score van alle buurten is in de separate Excel te vinden.

Tabel 4 Gemiddelde z-score Infrastructuur van buurten per hoogst en laagst scorende gemeente.

\begin{tabular}{lcrrr} 
Gemeentenaam & \multicolumn{2}{c}{ Hoogste score } & & Laagste score \\
\cline { 2 - 5 } Woudenberg & Butrtcode & z-score & Burtcode & z-score \\
\hline Baarn & BU03510004 & 0.05 & BU03510003 & -0.12 \\
\hline
\end{tabular}

In de gemeente Woudenberg zijn vier buurten meegenomen en buurt Laanzicht (BU03510004) scoort van deze buurten het hoogst voor de hoofdindicator Infrastructuur. Binnen deze buurten scoort het voetpad in het park Veldschans het hoogst.

Gemeente Baarn heeft vijf buurten in de analyse en buurt Pr. Hendrikpark (BU03080201) scoort daarbij het laagst op de hoofdindicator Infrastructuur. Binnen deze buurten scoort het voetpad langs Luitenant Generaal van Heutszlaan tussen Julianalaan en Prinses Irenelaan het laagst. Maar dit komt vooral omdat het voetpad GIS-matig grenst aan drie rijbanen, die allemaal afzonderlijk worden meegeteld.

\subsection{Knooppuntscore openbaar vervoer in de provincie}

De ov-knooppunten scoren iets beter op de loopmogelijkheden dan de buurten. Rond de ovknooppunten in een straal van $300 \mathrm{~m}$ ligt $76 \%$ aan voetpaden, $20 \%$ aan rijbanen en $4 \%$ aan fietspaden. Treinstation Amersfoort Centraal heeft met $94 \%$ de meeste voetpaden. ${ }^{5}$ Dit wordt met name bepaald door het relatief hoge percentage aan voetpaden-op-trappen (48\%) en voetgangersgebied (12\%). Het aandeel voetpaden rond dit station is erg beperkt, namelijk $33 \%$. Wanneer alleen voetpaden worden meegenomen, dus exclusief voetgangersgebied, voetpad-op-trap en inritten, dan heeft treinstation Utrecht Zuilen met $86 \%$ het hoogste percentage. Bushalte IJsselstein binnenstad heeft relatief het hoogste percentage aan voetgangersgebied (17\%). Treinstation Breukelen heeft met $24 \%$ de minste voetpaden. Dit knooppunt heeft in verhouding wel het hoogste percentage rijbanen, namelijk 63\%. Het ov-knooppunt met het minste percentage (4\%) aan rijbanen is Amersfoort Centraal.

Absoluut gezien heeft treinstation Houten de meeste voetpaden ${ }^{6}$ met bijna $19 \mathrm{~km}$, gevolgd door treinstation Leerdam met $17 \mathrm{~km}$. Busstation Lekbrug (west) in Vijfheerenlanden heeft met $3 \mathrm{~km}$ de minst absolute lengte aan voetpaden.

Tabel $5 \quad$ Verdeling loopmogelijkheden per type ov-knooppunt.

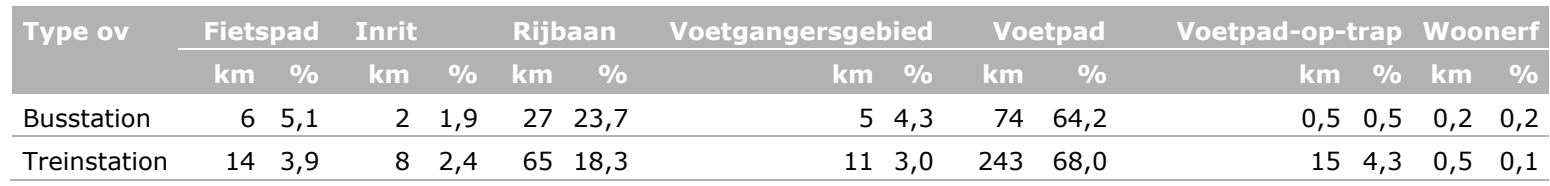

\footnotetext{
4 Een hoge z-score in de tabel wil dus NIET zeggen dat die buurt het beste in de provincie scoort, omdat niet de gemeenten onderling zijn vergeleken, maar de buurten in een specifieke gemeente.

5 Inclusief voetgangersgebied, voetpad-op-trap en inritten.

6 Inclusief voetgangersgebied, voetpad-op-trap en inritten.
} 
Uit tabel 5 blijkt dat de treinstations in verhouding meer lengte aan voetpaden hebben (68\%) dan de busstations (64\%). Het aandeel fietspaden is nagenoeg gelijk (5\%), dus bij busstations moet in verhouding meer over een rijbaan gelopen worden.

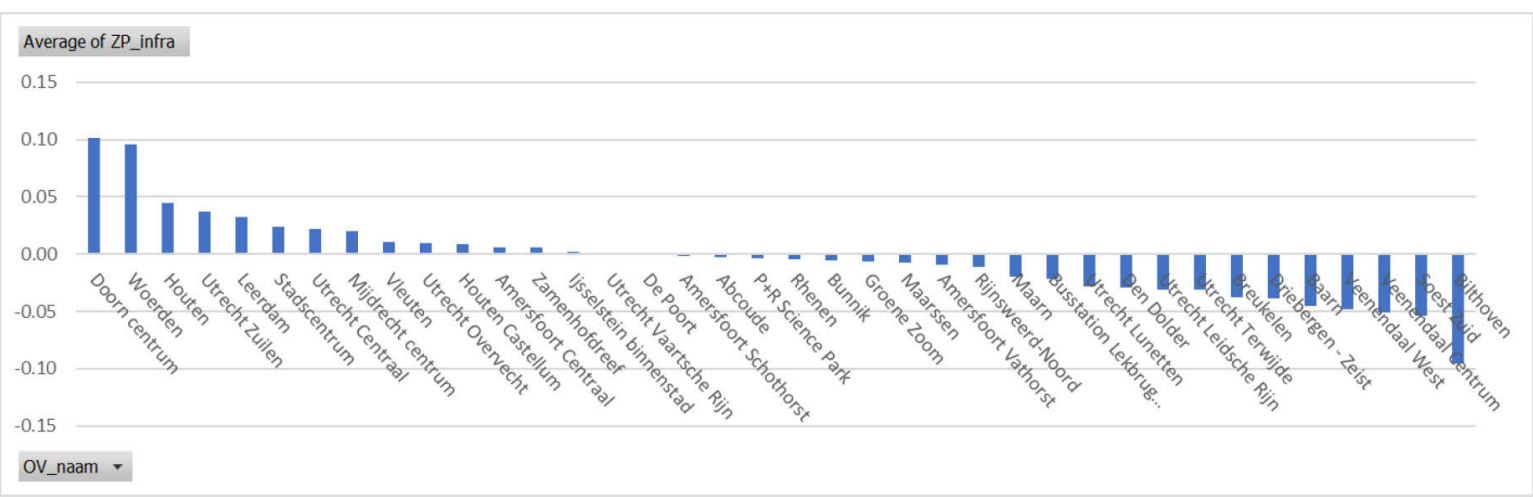

Figuur 3 Gemiddelde z-score infrastructuur per ov-knooppunt.

De ov-knooppunten zijn vervolgens in de hele provincie met elkaar vergeleken. De gemiddelde z-score per ov-knooppunt is berekend, omdat de indicatoren op een verschillende manier gemeten zijn. Hieruit blijkt dat bushalte Doorn-centrum, in verhouding tot andere ov-knooppunten in de provincie, het best scoort op de hoofdindicator Infrastructuur (figuur 3). Het treinstation Bilthoven scoort het minst.

De hoge score van Doorn-centrum komt vooral door twee voetpaden met een (in vergelijking met de werkelijkheid onterechte) lange berekende GIS-lengte die daardoor hoog scoren.

De aanwezige voetpaden in de buurten rond het treinstation Bilthoven liggen in $74 \%$ van de gevallen langs een of meer andere modaliteiten waardoor het minder rustig kan zijn.

\subsection{Reflectie}

De laagste infrastructuurscore heeft het voetgangersgebied onder treinstation Leidsche Rijn. Dit komt door veel modaliteiten en de grote lengte aan voetgangersgebied. De oppervlakten van de fietspaden en rijbanen (als diverse modaliteiten) die aan dit voetgangersgebied grenzen, zijn echter klein (soms een T-kruising). Aan het betreffende voetgangersgebied wordt GIS-technisch toch over de volle lengte de modaliteitsscore toebedeeld, terwijl dit in werkelijkheid meer een beperkt lengte is.

Het rekening houden met de lengte van een loopmogelijkheid is weliswaar terecht, maar geeft soms een vertekend beeld door de GIS-techniek die gebruikt is. Dit speelt vooral bij loopmogelijkheden waarvan de polygonen klein in oppervlakte zijn en/of grillig van vorm.

Wanneer een voetpad grenst aan een rijbaan die twee codes heeft, telt GIS twee modaliteiten bij het voetpad, terwijl het dezelfde rijbaan is.

Het is GIS-matig niet te achterhalen hoe vaak dit voorkomt, maar de indruk is dat dit beperkt voorkomt. Deze indruk is gebaseerd op het bestuderen van de GIS-kaart.

In vergelijking met de kaart van Openstreetmaps zijn een paar voetpaden niet in het GIS-systeem opgenomen (die gebaseerd is op de data van de BGT).

Maar het overgrote deel is wel opgenomen en daarmee is de BGT geschikt om als basis te dienen. Het grote voordeel is dat voetpaden aan beide zijden van een straat zijn opgenomen. Daarmee kan er beleid worden ontwikkeld voor zelfs een specifiek voetpad.

Een ander voordeel van het voetpad als eenheid is dat voor ontbrekende data burgers kunnen worden gevraagd om voor de voetpaden in hun eigen straat de data te leveren. Dit maakt het voor burgers makkelijker om mee te doen. 


\section{$4 \quad$ Omgevingskwaliteit}

\section{$4.1 \quad$ Inleiding}

In totaal zijn er acht indicatoren bij deze hoofdindicator. Van deze acht zijn er van alle acht data gevonden. Van vijf indicatoren is een bewerking gemaakt. Dit zijn de indicatoren Geluidshinder, Luchtkwaliteitsindex, Risico op wateroverlast, Hitte gevoelstemperatuur en Verkoelend effect van groen en blauw. De eerste vier indicatoren werken negatief door op de loopscore. De laatste indicator werkt positief op de loopscore. Van de indicatoren Geluidshinder bromfietsen en scooter, Geurhinder wegverkeer en Geurhinder bedrijven zijn vooralsnog geen berekeningen gemaakt, omdat deze data op wijk- of gemeenteniveau aanwezig zijn en dus geen onderscheid gemaakt kan worden op buurtniveau.

De data van de vijf indicatoren zijn meestal op rasterniveau. Per wegdeel is hiervan het gemiddelde genomen, zodat delen door lengte van een wegdeel niet meer hoeft.

\section{$4.2 \quad$ Buurtscore}

Uit tabel 6 blijkt dat de buurten in de gemeente Woudenberg gemiddeld het laagste geluidniveau (54 dB) hebben. Het is dus daar redelijk stil om te lopen. De buurten van de gemeente Stichtse Vecht hebben met gemiddeld $64 \mathrm{~dB}$ het hoogste geluidniveau. De buurten in Rhenen zijn gemiddeld het warmst (bijna $40 \mathrm{C}^{\circ}$ ) en in Baarn het minst warm. De buurten in Zeist geven gemiddeld de meeste koelte en in IJsselstein het minst. De luchtkwaliteit (LKI) is in de buurten in Utrechtse Heuvelrug gemiddeld het best en de buurten in de gemeente Utrecht hebben gemiddeld de meeste vervuiling. De minste risico op wateroverlast hebben de buurten in de Bilt en in Amersfoort gemiddeld het meest.

Tabel 6 Gemiddelde score per indicator en z-score bij Omgevingskwaliteit per gemeente.

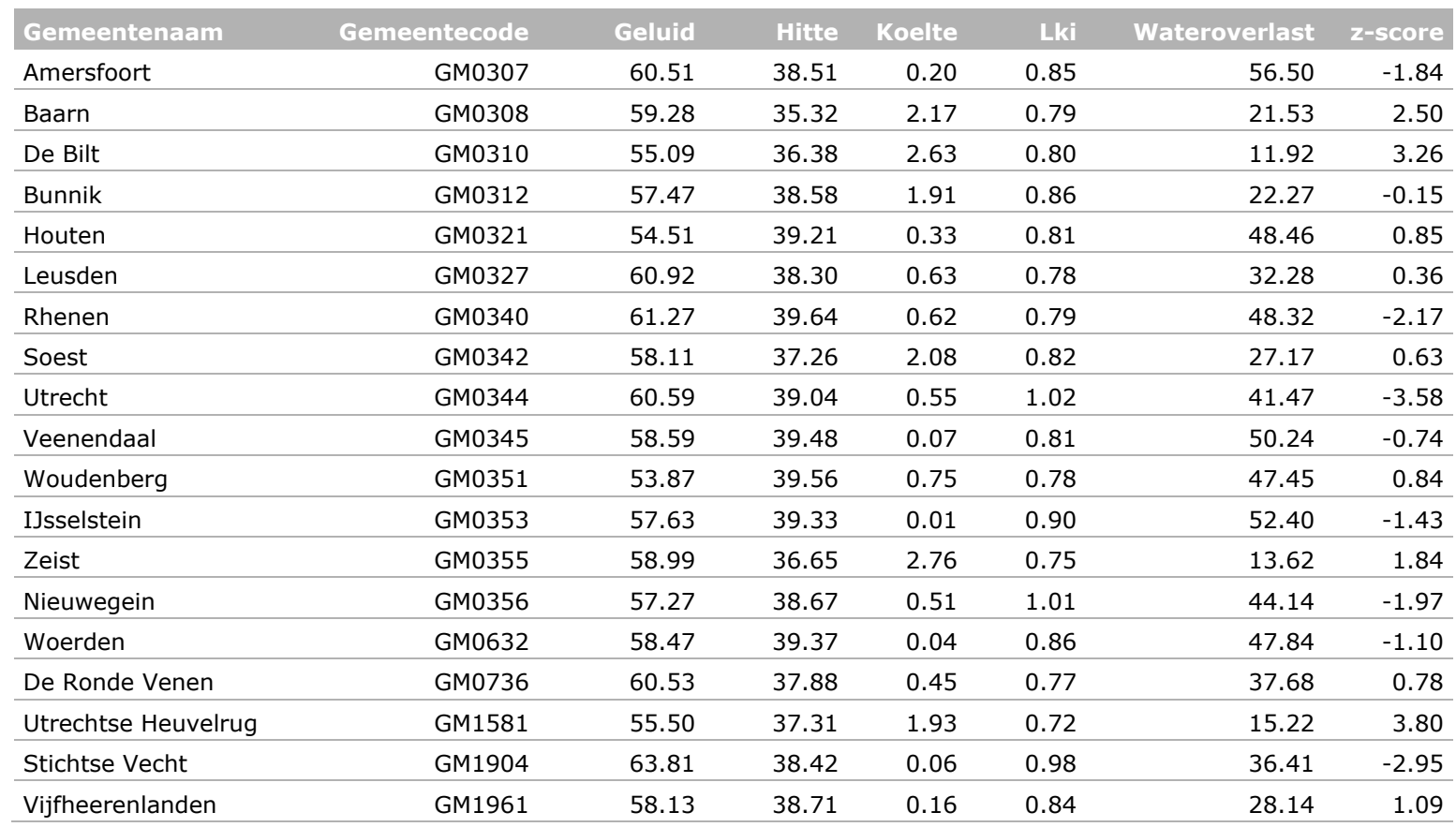


Wanneer de gemeenten onderling worden vergeleken op de hoofdindicator Omgevingskwaliteit via de z-score (tabel 6), dan scoort de gemeente de Utrechtse Heuvelrug het hoogst en de gemeente Utrecht het laagst.

De z-score van de hoofdindicator Omgevingskwaliteit van buurten van de hoogst en laagst scorende gemeente is weergegeven in tabel 7. Deze z-score is de som van de afzonderlijke z-scores van alle loopmogelijkheden in die buurt. De gemiddelde z-score is genomen, aangezien per buurt het aantal loopmogelijkheden verschilt. De z-score van alle buurten is in de separate Excel te vinden.

Tabel 7 Gemiddelde z-score Omgevingskwaliteit van buurten per hoogst en laagst scorende gemeente.

\begin{tabular}{lrrrr} 
Gemeentenaam & \multicolumn{1}{c}{ Hoogste score } & & \multicolumn{1}{c}{ Laagste score } \\
\hline Utrechtse Heuvelrug & Butrtcode & z-score & Butrtcode & 2-score \\
\hline Utrecht & BU15810003 & 1.32 & BU15810104 & -2.13 \\
\hline
\end{tabular}

De buurt Doorn-Zuid in de gemeente Utrechtse Heuvelrug (BU15810003) heeft van alle buurten in deze gemeente de hoogste score voor de hoofdindicator Omgeving. Een voetpad in deze buurt nabij de Molenweg in het landgoed Moersbergen heeft de hoogste z-score voor de omgevingskwaliteit.

Relatief minder doet een rijbaan het langs Vredenburg en een deel van de rijbaan Graadt van Roggenweg in buurt Hoog-Catharijne NS en Jaarbeurs (BU3440613) in de gemeente Utrecht. Deze rijbanen liggen net te ver van het naastliggende voetpad en zijn dus GIS-technisch geselecteerd, terwijl dat eigenlijk niet moet.

\subsection{Knooppuntscore openbaar vervoer}

Er is enig verschil in de score op de hoofdindicator Omgevingskwaliteit tussen de loopmogelijkheden rond treinstations $(-0,005)$ en bushaltes $(0,02)$. De bushaltes scoren iets beter op het verkoelend effect van groen (bomen e.d.) en blauw (water) en er is iets minder risico op wateroverlast. De overige indicatoren scoren hetzelfde.

Bij de hoofdindicator Omgevingskwaliteit scoort het treinstation Maarn het hoogst in vergelijking met andere ov-knooppunten in de provincie (figuur 4). Dit komt met name door een gemiddeld lage $\mathrm{C}^{\circ}$ als gevoelstemperatuur op een warme dag en de daarmee samenhangende hoge score op het verkoelend effect van groen (bomen e.d.) en blauw (water), een betere luchtkwaliteit en het beperkte risico op wateroverlast. De loopmogelijkheden rond het treinstation Utrecht Centraal scoren daarentegen het minst van alle Ov-knooppunten. Dit komt vooral door het hoge risico op wateroverlast, de beperkte luchtkwaliteit en een gemiddeld hoge $\mathrm{C}^{\circ}$ als gevoelstemperatuur op een warme dag.

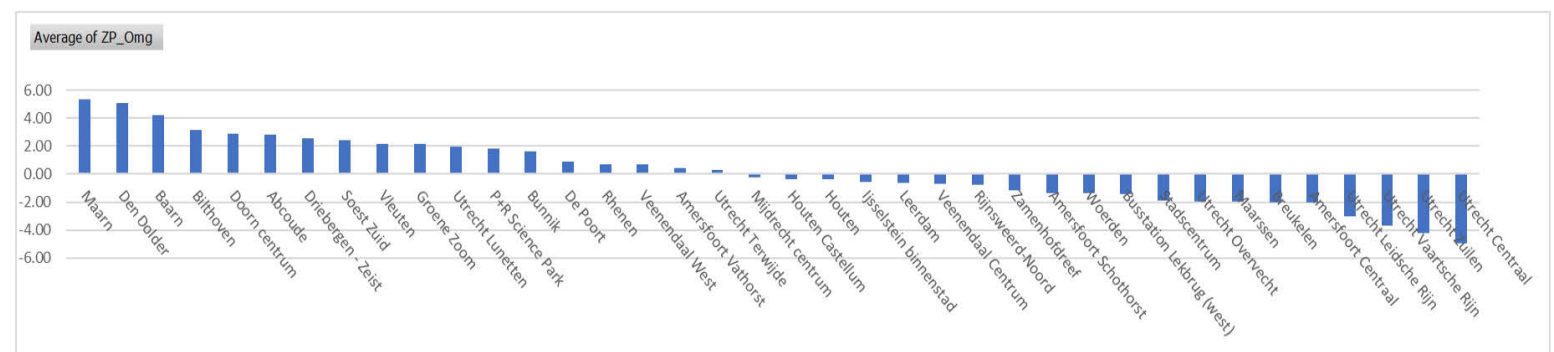

OV_naam .

Figuur 4 Gemiddelde z-score Omgevingskwaliteit per Ov-knooppunt. 


\section{$4.4 \quad$ Reflectie}

De indicator Risico op wateroverlast is gebaseerd op de kaart 'verharding per buurt', afkomstig uit de Klimaateffectatlas. Deze data zijn alleen op buurtniveau beschikbaar, zodat er geen onderscheid gemaakt kan worden tussen de verschillende loopmogelijkheden in een buurt. Al deze loopmogelijkheden krijgen dezelfde score.

Bij de indicator Hitte gevoelstemperatuur ontbreken er in $5 \%$ van de gevallen data, zodat een loopmogelijkheid geen score krijgt.

Het merendeel van de loopmogelijkheden kan echter een score krijgen voor de omgevingskwaliteit en daarmee zijn de data een goede indicatie voor de omgevingskwaliteit van een loopmogelijkheid.

Beleidsmatig is er met deze data een kans om het voetgangersbeleid te koppelen aan ander ruimtelijk beleid, zoals het klimaat en wateropvang.

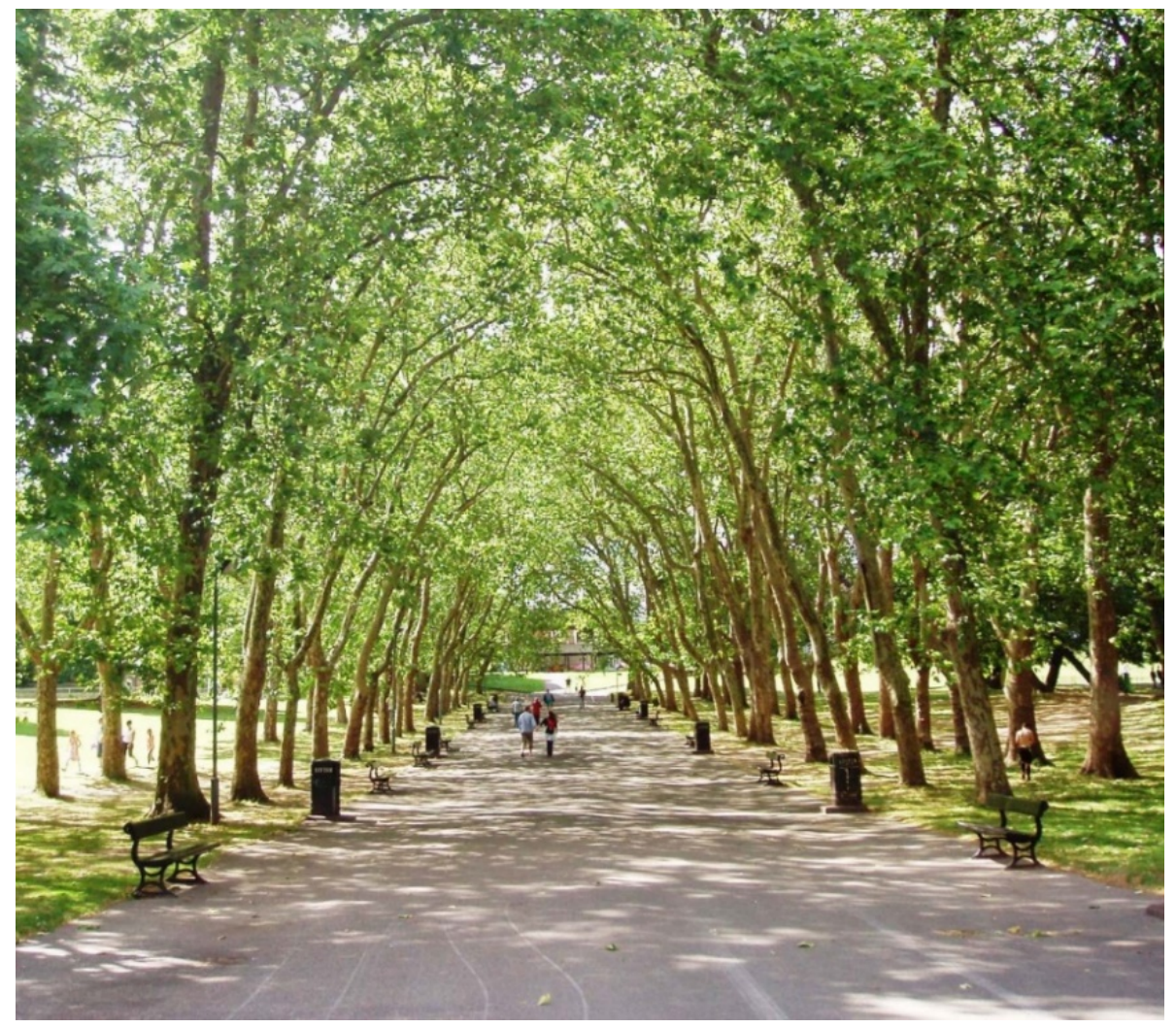

Foto 2 Bomen tegen de hitte (Bron: De groene stad.nI). 


\section{$5 \quad$ Directheid}

\section{$5.1 \quad$ Inleiding}

De kans is groter dat er meer gelopen wordt wanneer er veel voorzieningen in de directe omgeving van loopmogelijkheden liggen. De hoofdindicator Directheid bestaat uit negen indicatoren waarvan er bij acht indicatoren data gevonden zijn. Voor de indicator Doodlopende straten en steegjes zijn geen directe data gevonden. Wellicht dat dit via een aparte GIS-bewerking alsnog te bewerken valt. De indicator Verbinding voetpaden/netwerk is vooralsnog nog niet bewerkt, omdat dit meer op buurtniveau speelt. De volgende zeven indicatoren zijn bewerkt en er is berekend hoeveel voorzieningen in de nabijheid liggen van de loopmogelijkheden. Het gaat daarbij om essentiële voorzieningen, zoals scholen, gezondheidszorg en voedselwinkels, maar ook om speeltuinen, leisurevoorzieningen en publieke gebouwen. Ook de hoeveelheid Ov-haltes is een aparte indicator. Een afstand van $1000 \mathrm{~m}$ is gekozen voor scholen en gezondheidszorg. De fijnmazigheid van Ov-haltes is bepaald door een afstand van $800 \mathrm{~m}$ aan te houden. Voor de overige voorzieningen is deze afstand $500 \mathrm{~m}$.

\subsection{Buurtscore}

Tabel 8 laat zien dat de loopmogelijkheden in de gemeente Woerden binnen een afstand van $1000 \mathrm{~m}$ gemiddeld de meeste onderwijsinstellingen hebben. ${ }^{7}$ Voor gezondheidszorginstellingen is dit de gemeente Utrecht. Binnen een afstand van $500 \mathrm{~m}$ van de loopmogelijkheden heeft gemeente Woudenberg de meeste voedselwinkels. Voor speeltuinen is dit de gemeente Houten, voor leisurevoorzieningen (zoals een restaurant) de gemeente Woerden en de gemeente IJsselstein heeft gemiddeld de meeste publieke gebouwen die via de loopmogelijkheden bereikbaar zijn. De gemeente Utrecht heeft de meeste Ov-haltes die bereikbaar zijn binnen $500 \mathrm{~m}$ van een loopmogelijkheid.

Tabel $8 \quad$ Gemiddelde score per indicator en z-score bij directheid per gemeente.

\begin{tabular}{|c|c|c|c|c|c|c|c|c|c|}
\hline Gemeentenaam & $\begin{array}{r}\text { Gemeente } \\
\text { code }\end{array}$ & Onderwijs & Zorg & Voedsel & $\begin{array}{c}\text { Speel- } \\
\text { tuin }\end{array}$ & Leisure & $\begin{array}{l}\text { Publiek } \\
\text { gebouw }\end{array}$ & $\begin{array}{l}\text { Ov- } \\
\text { halte }\end{array}$ & z-score \\
\hline Amersfoort & GM0307 & 5.70 & 4.53 & 2.95 & 1.82 & 17.56 & 0.56 & 18.50 & 4.69 \\
\hline De Bilt & GM0310 & 0.93 & 1.73 & 0.94 & 0.13 & 2.77 & 0.30 & 10.63 & -6.53 \\
\hline Bunnik & GM0312 & 2.89 & 4.04 & 2.41 & 2.55 & 13.13 & 1.10 & 4.24 & 0.19 \\
\hline Leusden & GM0327 & 2.00 & 2.93 & 3.20 & 0.50 & 16.26 & 1.15 & 13.34 & 1.01 \\
\hline Rhenen & GM0340 & 0.77 & 1.74 & 1.64 & 0.40 & 9.16 & 0.76 & 12.56 & -3.74 \\
\hline Soest & GM0342 & 0.22 & 1.67 & 3.28 & 0.10 & 19.61 & 0.00 & 9.99 & -2.85 \\
\hline Utrecht & GM0344 & 5.64 & 8.13 & 3.21 & 1.60 & 28.32 & 1.57 & 21.76 & 10.54 \\
\hline Veenendaal & GM0345 & 3.08 & 4.24 & 1.24 & 1.31 & 10.54 & 0.54 & 13.77 & -0.88 \\
\hline Zeist & GM0355 & 0.14 & 1.87 & 1.20 & 0.03 & 2.86 & 0.11 & 8.02 & -7.44 \\
\hline Nieuwegein & GM0356 & 2.88 & 2.71 & 2.39 & 4.58 & 8.33 & 0.71 & 17.47 & 2.28 \\
\hline Woerden & GM0632 & 6.74 & 4.06 & 2.72 & 0.50 & 28.46 & 1.06 & 18.12 & 5.88 \\
\hline De Ronde Venen & GM0736 & 1.49 & 1.42 & 1.93 & 0.01 & 4.98 & 0.90 & 14.32 & -3.44 \\
\hline Utrechtse Heuvelrug & GM1581 & 0.00 & 2.01 & 2.47 & 0.00 & 7.51 & 0.70 & 9.68 & -4.20 \\
\hline Stichtse Vecht & GM1904 & 1.88 & 5.60 & 3.58 & 1.64 & 23.81 & 1.25 & 12.48 & 4.62 \\
\hline Vijfheerenlanden & GM1961 & 0.00 & 1.84 & 1.45 & 1.51 & 9.11 & 0.82 & 16.04 & -2.71 \\
\hline
\end{tabular}

7 Een voetpad aan één kant van de rijbaan heeft bijvoorbeeld 2 scholen op $1000 \mathrm{~m}$ afstand. Het voetpad aan de andere kant van de rijbaan heeft dezelfde 2 scholen. Gemiddeld per voetpad dus 2 scholen ( 4 scholen gedeeld door 2 voetpaden). 
Opvallend is dat de gemeente Woerden net iets hoger scoort op leisure dan de gemeente Utrecht. Dit komt omdat de buurten in Woerden centrumbuurten zijn (met veel leisure) en in Utrecht is ook een aantal woonbuurten (weinig leisure) meegenomen.

Wanneer de gemeenten onderling worden vergeleken op de hoofdindicator Directheid via de z-score (tabel 6), dan scoort de gemeente Utrecht het hoogst en de gemeente Zeist het laagst.

De z-score van de hoofdindicator Directheid van buurten van de hoogst en laagst scorende gemeente is weergegeven in tabel 9. Deze z-score is de som van de afzonderlijke z-scores van alle loopmogelijkheden in die buurt, gebaseerd op de indicatoren behorende bij de hoofdindicator Directheid. De gemiddelde z-score is genomen, aangezien per buurt het aantal loopmogelijkheden verschilt. De z-score van alle buurten is in de separate Excel te vinden.

Tabel 9 Gemiddelde z-score Directheid van buurten per hoogst en laagst scorende gemeente.

\begin{tabular}{lrrrr} 
Gemeentenaam & \multicolumn{2}{c}{ Hoogste score } & & Laagste score \\
\cline { 2 - 5 } Utrecht & Butrtcode & Z-score & Buurtcode & Z-score \\
\hline Zeist & BU03440613 & 14.94 & BU03440133 & -5.64 \\
\hline
\end{tabular}

Van alle gemeenten scoort gemeente Utrecht dus het hoogst op de hoofdindicator Directheid. Binnen de gemeente Utrecht scoort de buurt Hoog-Catharijne NS en Jaarbeurs (BU03440613) het hoogst met een z-score van 14,9. Binnen deze buurt scoort het voetpad Achter Clarenburg het hoogst met een z-score van 29,8 .

De gemeente Zeist scoort in verhouding met andere gemeenten minder goed. Binnen deze gemeente scoort de buurt Den Dolder-Noord (BU03550506) relatief het laagst $(-1,7)$. In deze buurt scoren 12 voetpaden, 2 inritten en 1 rijbaan en een fietspad allemaal het laagst, met een $z$-score van $-4,87$.

\subsection{Knooppuntscore openbaar vervoer}

De loopmogelijkheden rond treinstations in de provincie Utrecht scoren met een gemiddelde z-score van 0,03 net iets beter op de hoofdindicator Directheid dan bushaltes $(-0,09)$. Rond bushaltes zijn de loopmogelijkheden beter bedeeld met relatief meer publieke gebouwen, voedselwinkels en andere Ovhaltes, maar rond treinstations zijn er meer gezondheidszorgvoorzieningen, onderwijs, speeltuinen en leisurevoorzieningen.

Uit figuur 5 blijkt dat treinstation Utrecht Centraal verreweg het hoogst scoort op de directheid ten opzichte van andere Ov-knooppunten. De nabijheid van voorzieningen rond de loopmogelijkheden rond dit station scoort gemiddeld een 18,3. Dit treinstation scoort op alle voorzieningen het hoogst, behalve op de indicator Speeltuinen in de nabijheid. Treinstation Rhenen scoort gemiddeld het minst met -5. Andere Ov-knooppunten scoren soms lager op een bepaalde indicator, maar station Rhenen scoort vrij laag op alle indicatoren, waardoor het in totaal als laagste uitkomt. 


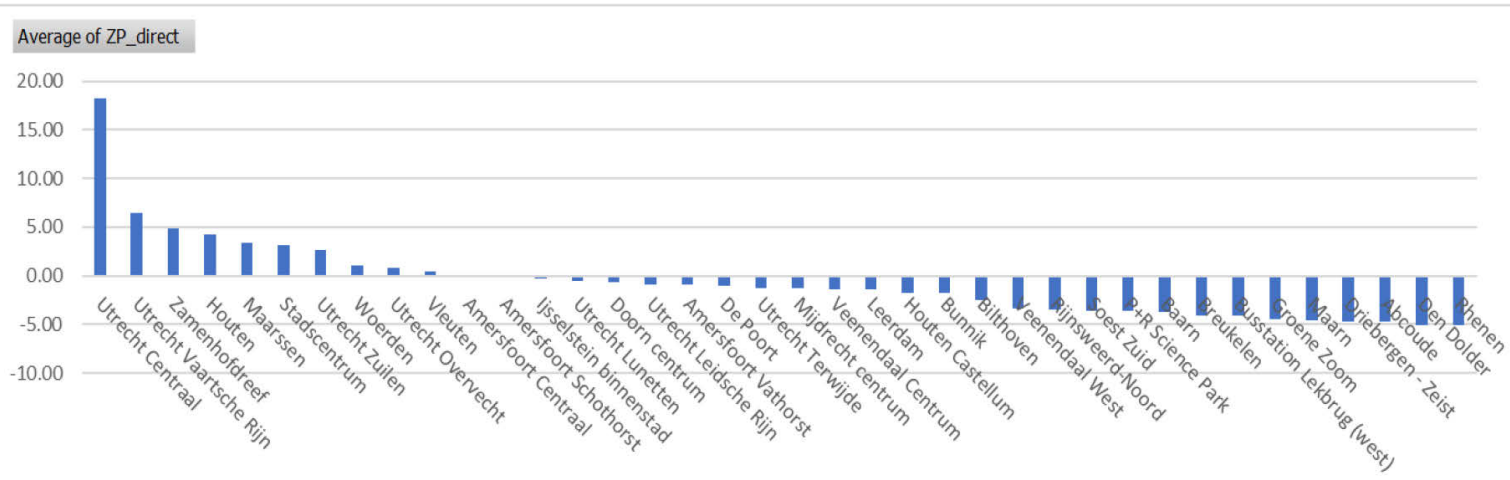

OV_naam -

Figuur 5 Gemiddelde z-score Directheid per Ov-knooppunt.

\subsection{Reflectie}

Uit de resultaten blijkt dat sommige loopmogelijkheden hoog scoren, maar dat de lengte van de loopmogelijkheid erg beperkt is. Soms niet eens $1 \mathrm{~m}$ lang. Dit komt eigenlijk bij elke hoofdindicator voor. Het is te overwegen om alle loopmogelijkheden met een beperkte lengte te verwijderen uit het systeem.

De indicator Verbinding voetpaden/netwerk is nu niet uitgewerkt, maar is wel op buurtniveau te bewerken door bijvoorbeeld de lengte van de loopmogelijkheden te delen door de oppervlakte van de buurt. De oppervlakte van de buurt is abusievelijk niet meegenomen in de databewerking, maar is dus wel mogelijk.

Redelijk veel data voor deze hoofdindicator zijn afkomstig uit de Openstreetmap (OSM). De indruk bestaat dat de Points of Interest uit de OSM een redelijk betrouwbaar beeld geven van de werkelijkheid, ook al is de OSM gebaseerd op vrijwilligers die data aanleveren en actualiseren. In de meeste gevallen gaf de OSM meer data dan de BGT.

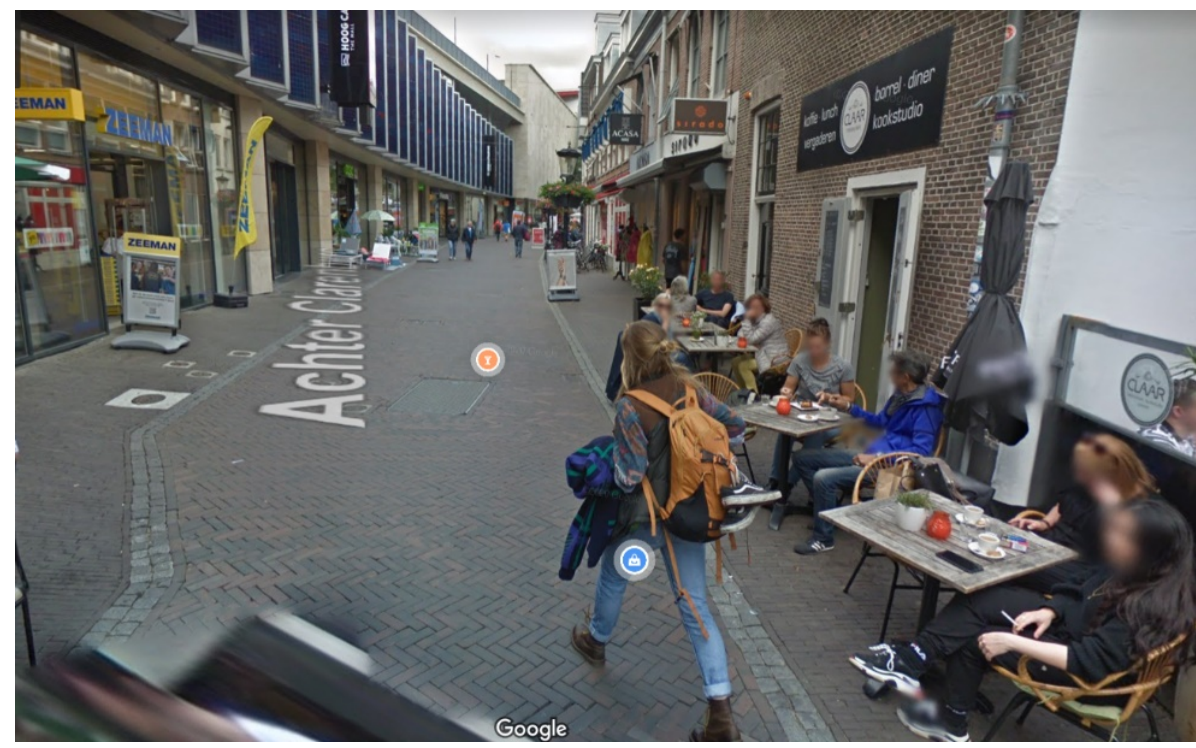

Foto 3 Achter Clarenburg in de gemeente Utrecht heeft de hoogste score voor Directheid voorzieningen. 


\section{Toegankelijkheid}

\section{$6.1 \quad$ Inleiding}

Deze hoofdindicator geeft aan in hoeverre het makkelijk is te lopen op een loopmogelijkheid. Deze hoofdindicator bestaat uit 32 indicatoren. Uit de literatuur blijkt dat dit gaat om de lengte, breedte en verharding van de loopmogelijkheid, maar ook of er molgoten, putdeksels, roosters en geleidelijnen in voorkomen. Ook de hoogte van de stoeprand en de hoogte van onderdoorgangen hebben invloed op de toegankelijkheid, evenals het hoogteverschil tussen het begin en eind van een voetpad. Met name voor oudere voetgangers kan dit een probleem zijn.

Daarnaast kunnen er allerlei barrières en obstakels op de loopmogelijkheid voorkomen waardoor de ruimte om te lopen beperkt wordt, zoals een abri, bolder, brievenbus, reclamebord, fietsenrek, telefooncel, boomspiegel, parkeermeter, container, glasbak, recycling, prullenbak, verkeersbord en palen, diverse kasten, openbare toiletten, terrassen en auto's die op het voetpad geparkeerd staan.

Ook het onderhoud aan een loopmogelijkheid is belangrijk, zoals het aanwezig zijn van boomwortels, scheef liggende tegels et cetera, maar ook de gladheid van het wegdekmateriaal (ook in de winter) heeft invloed.

Daarnaast wordt de toegankelijkheid groter indien er connecties zijn met andere gebieden via tunnels, loopbruggen, pontjes en spoorwegovergangen.

Ten slotte wordt er in de literatuur gewezen op het al dan niet aanwezig zijn van een wandelcultuur, het bewustzijn dat lopen gezond is en in hoeverre de loopmogelijkheid voor iedereen inclusief is. Met andere woorden, of er geen mensen worden uitgesloten van deelname aan lopen.

Van deze 32 indicatoren zijn van 9 (vooralsnog) geen data gevonden. Dit zijn de indicatoren Terras als barrière, Hoogte onderdoorgang, Hoogte stoeprand, Gladheid, Onderhoud loopmogelijkheid, Auto op voetpad, Wandelcultuur, Bewustzijn en Inclusiviteit. Van 5 indicatoren zijn wel data beschikbaar, maar niet voor dit project uitgewerkt, veelal omdat het per loopmogelijkheid minder onderscheidend is of GIS-technisch nog te ingewikkeld. Dit zijn de indicatoren Loopbruggen, Tunnels, Pontjes, Spoorwegovergang en Hoogteverschil.

De toegankelijkheid is dus gebaseerd op 18 indicatoren. Een looplengte tussen de 100 en $150 \mathrm{~m}$ krijgt de meeste punten, namelijk 3. Bij een lengte van een loopmogelijkheid kleiner dan 100 m moet men meer oversteken, maar is er wel meer connectiviteit en daarom krijgt deze lengte 2 punten. Bij meer dan $150 \mathrm{~m}$ wordt het al snel te saai en krijgt de loopmogelijkheid 1 punt. Bij de breedte van een loopmogelijkheid is ervan uitgegaan: hoe breder, hoe beter. Een onverharde loopmogelijkheid krijgt 1 punt, half verhard 2 punten en verhard 3 punten. Bij de molgoten en geleidelijnen is de aanname dat hoe langer de indicator is, hoe beter. Dit geldt niet voor de indicatoren die een barrièrewerking vormen. Daar geldt hoe meer, hoe minder toegankelijk en werkt dus negatief op de score.

\subsection{Buurtscore}

Bij deze hoofdindicator zijn er veel gemeenten die data van bepaalde indicatoren niet hebben geïnventariseerd. Dit betreft vooral indicatoren die met barrièrewerking te maken hebben. Alleen de gemeente Vijfheerenlanden heeft loopmogelijkheden waar een bolder als barrière op de stoep aanwezig is. De andere gemeenten hebben deze indicator niet of niet ingevuld. Alleen de gemeente Utrecht heeft loopmogelijkheden waar reclameborden, telefooncellen en parkeermeters de 
toegankelijkheid verminderen. De andere gemeenten hebben deze indicatoren niet of niet ingevuld. De indicatoren toiletten en boomspiegels zijn in slechts drie gemeenten genoteerd.

De meeste gemeenten hebben loopmogelijkheden tussen de 1 en $100 \mathrm{~m}$. Het gemiddelde over alle lengten is $49 \mathrm{~m}$. De gemeente Rhenen heeft in verhouding meer loopmogelijkheden tussen de 100 en $150 \mathrm{~m}$ en scoort daarom relatief het best op deze indicator (tabel 10). Gemeente Stichtse Vecht heeft langere loopmogelijkheden en scoort daarom relatief minder.

Gemeente De Ronde Venen heeft in verhouding de meest brede loopmogelijkheden, de gemeente Rhenen het minst. Wanneer alleen de voetpaden worden geselecteerd (38.669), dan is de gemiddelde breedte 2,22 $\mathrm{m}$. Rekening houdend met het 1,5m-afstandadvies in deze coronaperiode, moet een voetpad minimaal 2,7 m breed zijn. Om het coronaproof te maken, zou er dus minimaal $19 \mathrm{~km}$ aan voetpad moeten worden verbreed.

In de gemeente Baarn komen in verhouding de meest onverharde loopmogelijkheden voor en daarom scoort deze gemeente het laagst. Gemeente Amersfoort scoort op deze indicator relatief het hoogst. Molgoten komen in een beperkt aantal gemeenten niet voor of zijn niet ingevuld, maar gemeente Baarn scoort dan het best en Nieuwegein het minst. Voor de gemeente IJsselstein zijn relatief veel data gevonden voor de indicatoren die met barrièrewerking te maken hebben. De gemeente Houten daarentegen scoort relatief laag, maar is gebaseerd op 2 van de 13 barrière-indicatoren. Gemeente Stichtse Vecht doet het relatief goed met de geleidelijnen. Er zijn veel gemeenten die het minder doen.

Tabel 10 Gemiddelde score per indicator en z-score bij Toegankelijkheid per gemeente.

\begin{tabular}{|c|c|c|c|c|c|c|c|c|}
\hline Gemeentenaam & $\begin{array}{r}\text { Gemeente } \\
\text { code }\end{array}$ & Looplengte & Breedte & Verharding & Molgoot & Barrière & $\begin{array}{r}\text { Lengte } \\
\text { geleidelijn }\end{array}$ & z-score \\
\hline Amersfoort & GM0307 & 1.99 & 2.65 & 2.99 & - & 12 & 0.50 & 1.51 \\
\hline De Bilt & GM0310 & 1.98 & 2.48 & 2.94 & 18.11 & 46 & 0.09 & -2.74 \\
\hline Bunnik & GM0312 & 1.99 & 2.41 & 2.96 & - & 16 & 0.05 & -0.30 \\
\hline Leusden & GM0327 & 1.98 & 2.90 & 2.89 & - & 8 & 0.00 & -0.11 \\
\hline Rhenen & GM0340 & 2.05 & 2.23 & 2.97 & - & 29 & 0.02 & 0.19 \\
\hline Soest & GM0342 & 1.98 & 2.53 & 2.97 & - & 34 & 0.00 & -3.50 \\
\hline Utrecht & GM0344 & 2.04 & 2.93 & 2.98 & 7.12 & 28 & 0.07 & 3.12 \\
\hline Zeist & GM0355 & 1.97 & 2.67 & 2.90 & 14.50 & 19 & 0.86 & 1.17 \\
\hline Nieuwegein & GM0356 & 2.01 & 2.96 & 2.99 & 1.33 & 21 & 0.19 & 1.68 \\
\hline Woerden & GM0632 & 2.01 & 2.58 & 2.98 & - & 6 & 0.00 & 0.53 \\
\hline De Ronde Venen & GM0736 & 1.98 & 3.02 & 2.92 & 6.62 & 15 & 0.00 & 1.77 \\
\hline Utrechtse Heuvelrug & GM1581 & 1.98 & 2.29 & 2.91 & - & 22 & 0.00 & -3.14 \\
\hline Stichtse Vecht & GM1904 & 1.94 & 2.98 & 2.96 & 18.84 & 6 & 1.60 & 4.67 \\
\hline Vijfheerenlanden & GM1961 & 2.01 & 2.33 & 2.97 & - & 21 & 0.00 & -0.15 \\
\hline
\end{tabular}

Voor de totale z-score voor de hoofdindicator Toegankelijkheid scoort de gemeente Stichtse Vecht relatief het hoogst (tabel 10). Dit komt met name door de geleidelijnen, weinig barrières en brede loopmogelijkheden. Gemeente Soest scoort relatief het laagst. Dit komt vooral door de barrièrewerking van de aanwezige putten. Dit is echter een potentiële barrière, want het kan goed zijn dat de putten in werkelijkheid goed beloopbaar zijn en niet boven het maaiveld uitkomen.

In tabel 11 staat de z-score van de hoofdindicator Toegankelijkheid van de buurten van de hoogst en laagst scorende gemeente. Deze z-score van een buurt is de som van alle afzonderlijke z-scores van de loopmogelijkheden in die buurt. De z-score van alle buurten is in de separate Excel te vinden. 
Tabel 11 Gemiddelde z-score Toegankelijkheid van buurten per hoogst en laagst scorende gemeente.

\begin{tabular}{|c|c|c|c|c|}
\hline \multirow[t]{2}{*}{ Gemeentenaam } & \multicolumn{2}{|c|}{ Hoogste score } & \multicolumn{2}{|c|}{ Laagste score } \\
\hline & Buurtcode & z-score & Buurtcode & z-score \\
\hline Stichtse Vecht & BU19040205 & 0.85 & BU19040214 & -0.94 \\
\hline
\end{tabular}

Van alle buurten in de gemeente Stichtse Vecht scoort de Polder Breukelerwaard (BU19040205) het hoogst op de hoofdindicator Toegankelijkheid. Binnen deze gemeente scoort een fietspad op de brug over de rivier AA het hoogst. Dit komt vooral door de geleidelijn en de breedte. Het is echter de vraag of de ligging van de geleidelijn juist is.

In de gemeente Soest scoort een lang en onverhard voetpad in het verlengde van de Enghenbergsteeg in de buurt De Eng-Zuid (BU03420405) het minst op Toegankelijkheid.

\subsection{Knooppuntscore openbaar vervoer}

De loopmogelijkheden rond bushaltes in de provincie Utrecht scoren met een gemiddelde z-score van 0,06 net iets beter op de hoofdindicator Toegankelijkheid dan treinstations $(-0,02)$. Rond bushaltes zijn de loopmogelijkheden breder en zijn er minder barrières. Maar de hoge score voor barrières in de vorm van containers/afvalbakken bij treinstations komt vooral door het Centraal Station Amersfoort. Ook nu is een GIS-bewerking verantwoordelijk voor deze (onterechte) hoge score.

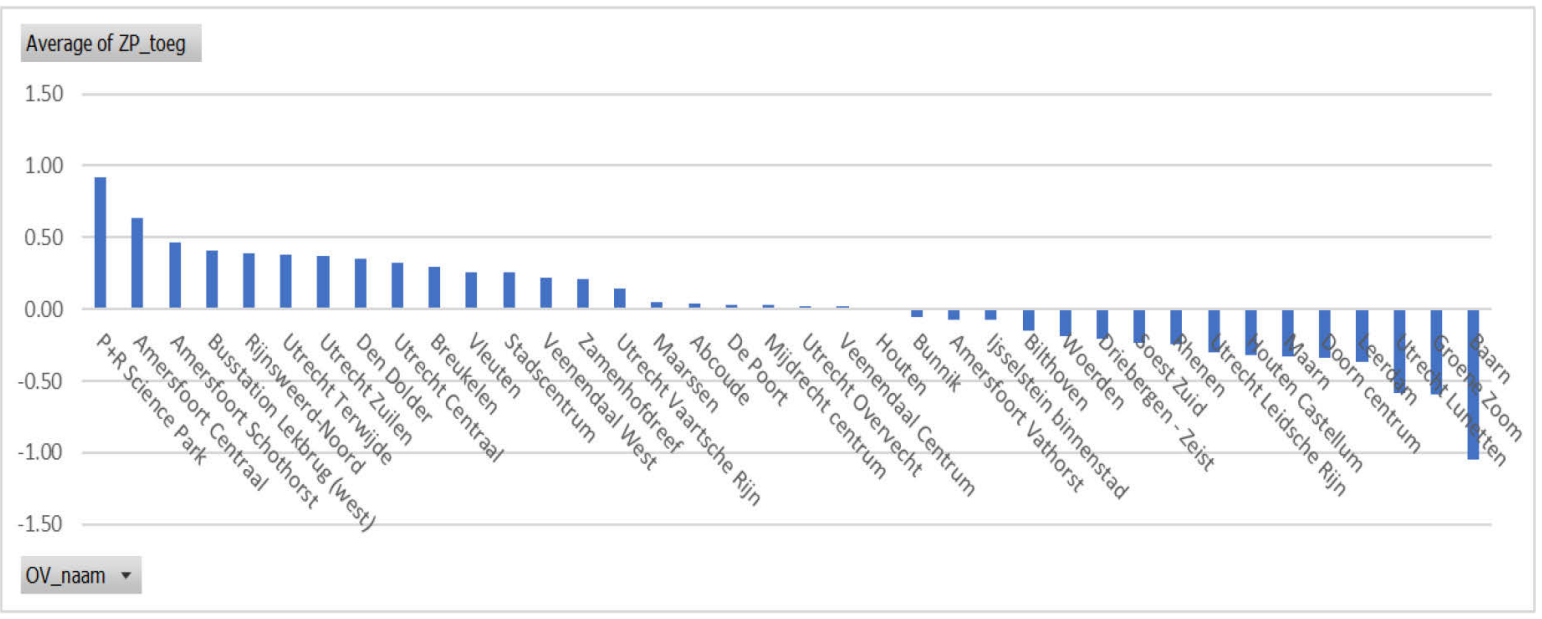

Figur 6 Gemiddelde z-score Toegankelijkheid per Ov-knooppunt.

Uit figuur 6 blijkt dat bushalte P+R Science Park in de gemeente Utrecht het hoogst scoort op Toegankelijkheid in de provincie. Dit komt vooral door de geleidelijnen, de breedte van de loopmogelijkheden en de verharding. Treinstation Baarn scoort relatief laag in de provincie. Dit komt vooral door de relatief vele onverharde voetpaden die ook vaak een lange lengte hebben.

\subsection{Reflectie}

De lengte van het wegdeel blijkt in het verloop van de analyse een belangrijk element te zijn. Niet alleen worden sommige indicatoren gedeeld door de lengte, ook voor de berekening van de breedte wordt dit getal gebruikt, namelijk de oppervlakte van de polygoon gedeeld door de lengte.

Een flink aantal indicatoren valt onder het niet-verplichte deel van de BGT en de data zijn dan ook niet in alle loopmogelijkheden en buurten aanwezig en/of volledig. Het is echter moeilijk in te schatten of 
er bijvoorbeeld een type barrière (zoals een fietsenrek) echt niet voorkomt of niet voorkomt omdat het niet is ingevuld.

De kwaliteit van de score voor de hoofdindicator Toegankelijkheid is nogal dubbel. Aan de ene kant geeft het een redelijke indicatie van de breedte, lengte en verharding van een loopmogelijkheid. Aan de andere kant ontbreken er veel data om de barrièrewerking goed in beeld te kunnen brengen, evenals indicatoren die voor een bepaalde doelgroep (zoals met voetgangers met een fysieke beperking) van belang zijn zoals geleidelijnen. 


\section{$7 \quad$ Levendigheid}

\section{$7.1 \quad$ Inleiding}

Uit de literatuur blijkt dat een levendige straat de loopbaarheid vergroot. Een levendige straat wil niet alleen zeggen dat er veel voetgangers zijn, maar ook dat er iets te doen valt of te zien is. Deze hoofdindicator bestaat uit 12 indicatoren, waarbij er van 7 data gevonden zijn die gekoppeld zijn aan de loopmogelijkheid. Dit zijn de indicatoren Leegstaande en vervallen gebouwen die de levendigheid beperken en dus negatief werken op de score, Bankjes, Pleintjes, Speeltuin binnen $10 \mathrm{~m}$ van een loopmogelijkheid, Diversiteit door menging van wonen en werken, Overkapping/luifel zodat in elk weertype gelopen kan worden en Bedrijvigheid van de plint is een mix van functies (met name leisure en voedsel). Een plein is gedefinieerd als een voetgangersgebied uit de BGT van minimaal 0,1 ha en een minimale lengte en breedte van $25 \mathrm{~m}$, verhard en niet in een groengebied. Hoe hoger het percentage wonen, hoe minder gemengde functies er voorkomen. Het percentage werkt dus negatief mee in de score. Een percentage van $100 \%$ woningen is verwijderd, want dan is er ook geen menging.

Van 5 indicatoren zijn geen data gevonden. Dit betreft Sociale activiteiten, Straatmuzikanten, loopdrukte, Terrassen en Openluchtpodium.

\subsection{Buurtscore}

Alleen de gemeente Utrecht heeft data voor alle 7 indicatoren. Van de indicator Leegstaande gebouwen zijn in ongeveer de helft van de gemeenten geen data aanwezig. De gemeente Stichtse Vecht scoort op deze indicator relatief het best. De gemeente Soest heeft in verhouding de meeste bankjes en gemeente IJsselstein de meeste speeltuinen. Gemeente Baarn heeft met $91 \%$ woningen de meest gemengde functies. Van de indicator Luifel zijn in 9 gemeente geen data gevonden. Gemeente IJsselstein scoort hierop relatief het best. De meeste bedrijvigheid komt in de gemeente Stichtse Vecht voor. Pleinen komen volgens de gehanteerde definitie in slechts 3 gemeenten voor.

Tabel 12 Gemiddelde score per indicator en z-score bij Levendigheid per gemeente.

\begin{tabular}{|c|c|c|c|c|c|c|c|c|c|}
\hline Gemeentenaam & $\begin{array}{r}\text { Gemeente } \\
\text { code }\end{array}$ & Leegstand & Bankje & Speeltuin & $\begin{array}{r}\% \\
\text { wonen }\end{array}$ & Luifel & Bedrijvig & Plein & z-score \\
\hline Amersfoort & GM0307 & 1.60 & 5.79 & 1.38 & 96.97 & - & 2.09 & 1.00 & -1.02 \\
\hline De Bilt & GM0310 & 1.72 & 0.87 & 4.69 & 94.96 & - & 1.62 & - & -0.42 \\
\hline Bunnik & GM0312 & - & 2.55 & 3.12 & 96.95 & 4.32 & 2.81 & - & -1.28 \\
\hline Leusden & GM0327 & - & 9.45 & - & 93.50 & - & 1.18 & - & 0.83 \\
\hline Rhenen & GM0340 & - & 2.99 & - & 97.46 & - & 4.54 & - & 0.21 \\
\hline Soest & GM0342 & - & 13.26 & - & 94.03 & 1.82 & 3.84 & - & 3.49 \\
\hline Utrecht & GM0344 & 6.19 & 5.55 & 1.86 & 94.58 & 9.09 & 3.27 & 1.00 & 0.18 \\
\hline Zeist & GM0355 & 2.43 & 0.43 & - & 92.38 & - & 1.31 & - & -0.65 \\
\hline Nieuwegein & GM0356 & - & 5.27 & 2.06 & 95.77 & 4.82 & 2.04 & 1.00 & -1.03 \\
\hline Woerden & GM0632 & - & 1.59 & 0.92 & 93.10 & 0.84 & 3.46 & - & -0.54 \\
\hline De Ronde Venen & GM0736 & 1.80 & 0.93 & - & 92.97 & 1.31 & 3.61 & - & 0.91 \\
\hline Utrechtse Heuvelrug & GM1581 & 7.46 & 3.49 & - & 96.13 & 1.97 & 3.75 & - & -2.22 \\
\hline Stichtse Vecht & GM1904 & 0.46 & 0.96 & 6.93 & 97.58 & - & 4.89 & - & 2.86 \\
\hline Vijfheerenlanden & GM1961 & 4.81 & 1.82 & 0.95 & 94.35 & 3.10 & 2.90 & - & -1.97 \\
\hline
\end{tabular}


Wanneer alle indicatoren met elkaar worden vergeleken via de z-score, dan laat tabel 12 zien dat de gemeente Soest in verhouding het hoogst scoort op levendigheid. Dit komt vooral door de bedrijvigheid aan de plint, de speeltuinen en de beperkte leegstand. De gemeente Utrechtse Heuvelrug scoort in verhouding het minst van de provincie op deze hoofdindicator.

In tabel 13 staat de z-score van de hoofdindicator Levendigheid van de buurten van de hoogst en laagst scorende gemeente. Deze z-score van een buurt is de som van alle afzonderlijke z-scores van de loopmogelijkheden in die buurt. De z-score van alle buurten is in de separate Excel te vinden.

Tabel 13 Gemiddelde z-score Levendigheid van burten per hoogst en laagst scorende gemeente.

\begin{tabular}{lcrrr} 
Gemeentenaam & \multicolumn{3}{c}{ Hoogste score } & \multicolumn{2}{c}{ Laagste score } \\
\cline { 2 - 5 } Soest & Buurtcode & z-score & Buurtcode & z-score \\
\hline Utrechtse Heuvelrug & BU03420701 & 0.02 & BU03420606 & -0.19 \\
\hline
\end{tabular}

De buurt Soest-Zuid (BU03420701) scoort in deze gemeente het hoogst voor de hoofdindicator Levendigheid. In deze buurt scoort de Acacialaan het hoogst. Maar deze laan heeft alleen een score voor percentage wonen, dat met $8 \%$ vrij laag is. Volgens de kaart lijkt dit niet helemaal terecht. De buurt Doorn-centrum in de gemeente Utrechtse Heuvelrug scoort relatief laag. Binnen deze buurt scoort een voetpad aan de Zonnehuis het laagst. Dat is echter een voetpad met een kleine oppervlakte waarbij de leegstand als enige indicator scoort.

\subsection{Knooppuntscore openbaar vervoer}

De loopmogelijkheden rond bushaltes in de provincie Utrecht scoren met een gemiddelde z-score van 0,07 net iets beter op de hoofdindicator Levendigheid dan treinstations $(-0,02)$. Rond bushaltes is er minder leegstand, zijn er meer overkappingen/luifels en meer gemengde functies. Treinstations hebben in de omgeving meer bankjes, meer speeltuinen en pleinen en meer bedrijvigheid aan de plint.

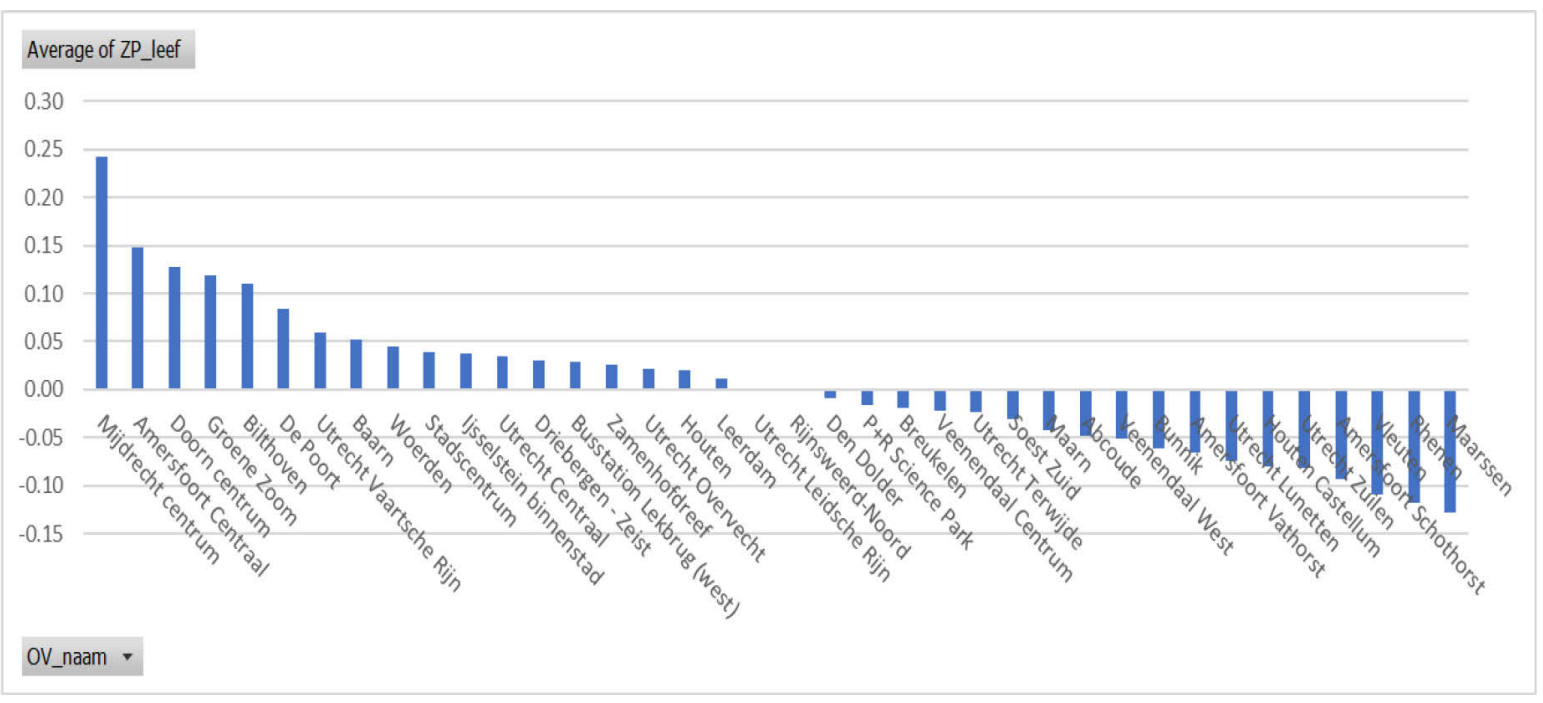

Figuur 7 Gemiddelde z-score Levendigheid per Ov-knooppunt.

Bushalte Mijdrecht centrum scoort het hoogst op de hoofdindicator Levendigheid. Dit komt vooral door de relatief veel gemengde functies en de bedrijvigheid aan de plint. Treinstation Maarssen scoort het minst op Levendigheid. Dit komt omdat het voor 99\% uit woningen bestaat en dus weinig gemengde functies heeft. 


\subsection{Reflectie}

Het aantal leegstaande gebouwen is gebaseerd op de BAG. De werkelijkheid zal anders zijn, gezien de opname en verwerkingsperiode van de BAG. De definitie van een plein is niet helemaal goed. Er vallen te veel pleintjes af wanneer naar de kaart wordt gekeken. Misschien is het beter om op de naam 'plein' of 'markt' te selecteren.

De z-score is alleen berekend bij indicatoren waarvoor data aanwezig zijn. Sommige loopmogelijkheden hebben data van slechts één indicator, bijvoorbeeld alleen voor indicator Percentage wonen. De z-score kan dan hoger uitvallen in vergelijking met loopmogelijkheden die data van meer indicatoren hebben, maar in verhouding een negatieve z-score krijgen. 'Geen data' scoort dan hoger dan 'wel data' en dat is niet helemaal terecht.

Om een goed beeld te krijgen van de levendigheid ontbreken er data van belangrijke indicatoren, zoals de loopdrukte en aanwezige terrassen. De indicatoren waarvan wel data zijn, komen in beperkte mate voor of zijn niet ingevuld. Dit met uitzondering van de indicatoren Gemengde functies en Bedrijvigheid. Door de aanwezigheid van redelijk betrouwbare data voor deze twee indicatoren, geeft de score toch een eerste beeld van de levendigheid, maar verbeteringen zijn wel aan te bevelen. Bijvoorbeeld via een indicatie van de loopdrukte.

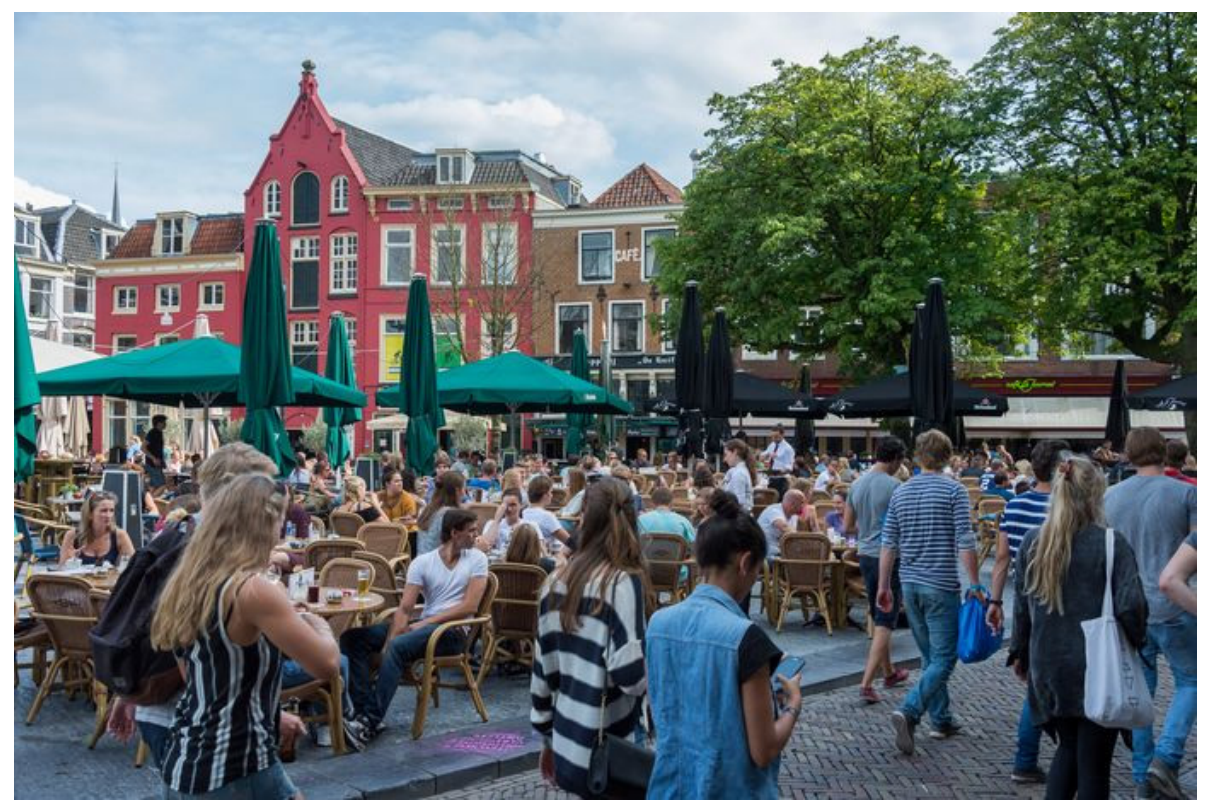

Foto 4 Terrassen en Loopdrukte zijn belangrijke indicatoren voor hoofdindicator Levendigheid, maar data hierover ontbreken vaak (Bron: $A D . n l)$. 


\section{$8 \quad$ Allure}

\section{$8.1 \quad$ Inleiding}

De hoofdindicator Allure geeft een bepaalde mate van aantrekkingskracht voor voetgangers. Daarmee kunnen buurten zich onderscheiden van andere buurten. Buurten met allure zijn vaak ook interessant voor toeristen. Het zijn buurten waar mensen naartoe gaan. De hoofdindicator Allure bestaat uit 5 indicatoren en van alle 5 zijn data gevonden. Dit zijn de indicatoren Oude gebouwen, theater, musea, kastelen en overige leisurevoorzieningen op maximaal $10 \mathrm{~m}$ afstand van een loopmogelijkheid, Rijksmonumenten, Boulevard- of wandelpromenade en de Hoogte van gebouwen.

Oude gebouwen zijn gebouwen ouder dan 1850. De allure wordt anders beleefd als er 10 oude gebouwen aan $50 \mathrm{~m}$ loopmogelijkheid staan dan aan $500 \mathrm{~m}$ loopmogelijkheid. Daarom is de lengte van de loopmogelijkheid meegenomen en wordt het aantal oude gebouwen per $100 \mathrm{~m}$ weergegeven. Dit geldt ook voor theater, musea, kastelen en overige leisurevoorzieningen.

Boulevard- of wandelpromenade zijn voetpaden van minimaal $10 \mathrm{~m}$ breed en minimaal $200 \mathrm{~m}$ lang.

Hoge gebouwen zoals wolkenkrabbers kunnen een bepaalde allure geven. Vandaar dat alle gebouwen hoger dan $50 \mathrm{~m}$ zijn meegenomen via het BAG_3D bestand.

Data over Rijksmonumenten komen van de provincie Utrecht en zijn alle punten, lijnen en vlakken.

Alle indicatoren zijn berekend via de methode: hoe meer, hoe hoger de score.

\subsection{Buurtscore}

Alleen de gemeenten Utrecht en Amersfoort scoren op alle 5 indicatoren en als enige op pandhoogte. De gemeente IJsselstein heeft per $100 \mathrm{~m}$ gemiddeld de meeste oude gebouwen en Woerden de meeste leisurevoorzieningen. Gemeente Vijfheerenlanden heeft de meeste Rijksmonumenten. Gemeente Nieuwegein heeft de langste boulevard.

Tabel 14 Gemiddelde score per indicator en z-score bij Allure per gemeente.

\begin{tabular}{|c|c|c|c|c|c|c|c|}
\hline Gemeentenaam & Gemeentecode & Oud gebouw & Leisure & Rijksmonument & Boulevard & Pandhoogte & z-score \\
\hline Amersfoort & GM0307 & 0.00 & 0.03 & 0.01 & 245 & 55.17 & -2.64 \\
\hline Baarn & GM0308 & 0.00 & 0.02 & 0.06 & - & - & -0.26 \\
\hline Bunnik & GM0312 & 0.01 & 0.03 & 0.02 & - & - & -0.53 \\
\hline Houten & GM0321 & 0.00 & 0.01 & 0.03 & - & - & -1.49 \\
\hline Soest & GM0342 & 0.00 & 0.06 & 0.01 & - & - & 0.44 \\
\hline Utrecht & GM0344 & 0.07 & 0.04 & 0.05 & 305 & 60.97 & 2.20 \\
\hline Veenendaal & GM0345 & 0.00 & 0.01 & 0.00 & - & - & -2.71 \\
\hline Woudenberg & GM0351 & 0.00 & 0.06 & 0.01 & - & - & 0.25 \\
\hline Woerden & GM0632 & 0.10 & 0.07 & 0.06 & - & - & 4.18 \\
\hline De Ronde Venen & GM0736 & 0.01 & 0.02 & 0.02 & - & - & -1.30 \\
\hline Utrechtse Heuvelrug & GM1581 & 0.01 & 0.02 & 0.05 & - & - & -0.16 \\
\hline Stichtse Vecht & GM1904 & 0.00 & 0.03 & 0.01 & - & - & -1.28 \\
\hline Vijfheerenlanden & GM1961 & 0.15 & 0.02 & 0.11 & - & - & 4.36 \\
\hline
\end{tabular}


Wanneer alle indicatoren met elkaar worden vergeleken via de z-score, dan laat tabel 14 zien dat in verhouding de gemeente Vijfheerenlanden het hoogst scoort op Allure. Dit komt met name door de relatief vele Rijksmonumenten en oude panden. Gemeente Veenendaal scoort in verhouding minder op Allure door met name het juist ontbreken van oude panden en Rijksmonumenten in de buurten rond de Ov-knooppunten.

In tabel 15 staat de z-score van de hoofdindicator Allure van de buurten van de hoogst en laagst scorende gemeente. Deze z-score van een buurt is de som van alle afzonderlijke z-scores van de loopmogelijkheden in die buurt. De z-score van alle buurten is in de separate Excel te vinden.

Tabel 15 Gemiddelde z-score Allure van buurten per hoogst en laagst scorende gemeente.

\begin{tabular}{lcccr} 
& \multicolumn{3}{c}{ Hoogste score } & \multicolumn{2}{c}{ Laagste score } \\
\cline { 2 - 5 } Vemeentenaam & Buurtcode & z-score & Burtcode & z-score \\
Vijfheerenlanden & BU19610100 & 0.21 & BU19610001 & -0.12 \\
\hline Veenendaal & BU03450300 & 0.01 & BU03450301 & -0.00 \\
\hline
\end{tabular}

De buurt Oude Stad (BU19610100) in Vianen, gemeente Vijfheerenlanden, scoort binnen deze gemeente het hoogst op de hoofdindicator Allure. Een voetpad van beperkte lengte ( $4 \mathrm{~m}$ ) aan de Voorstraat scoort het hoogst als gevolg van de aanwezige theater- en andere leisurevoorzieningen en Rijksmonumenten. De buurt Franse Gat (BU03450301) scoort met diverse loopmogelijkheden in de gemeente Veenendaal het minst op Allure.

\subsection{Knooppuntscore openbaar vervoer}

De loopmogelijkheden rond bushaltes in de provincie Utrecht scoren met een gemiddelde z-score van 0,03 net iets beter op de hoofdindicator Allure dan treinstations $(-0,01)$. Het aantal oude gebouwen is meer aanwezig rond bushaltes dan rond treinstations. Rond treinstations zijn weer meer leisurevoorzieningen, Rijksmonumenten en hoge panden.

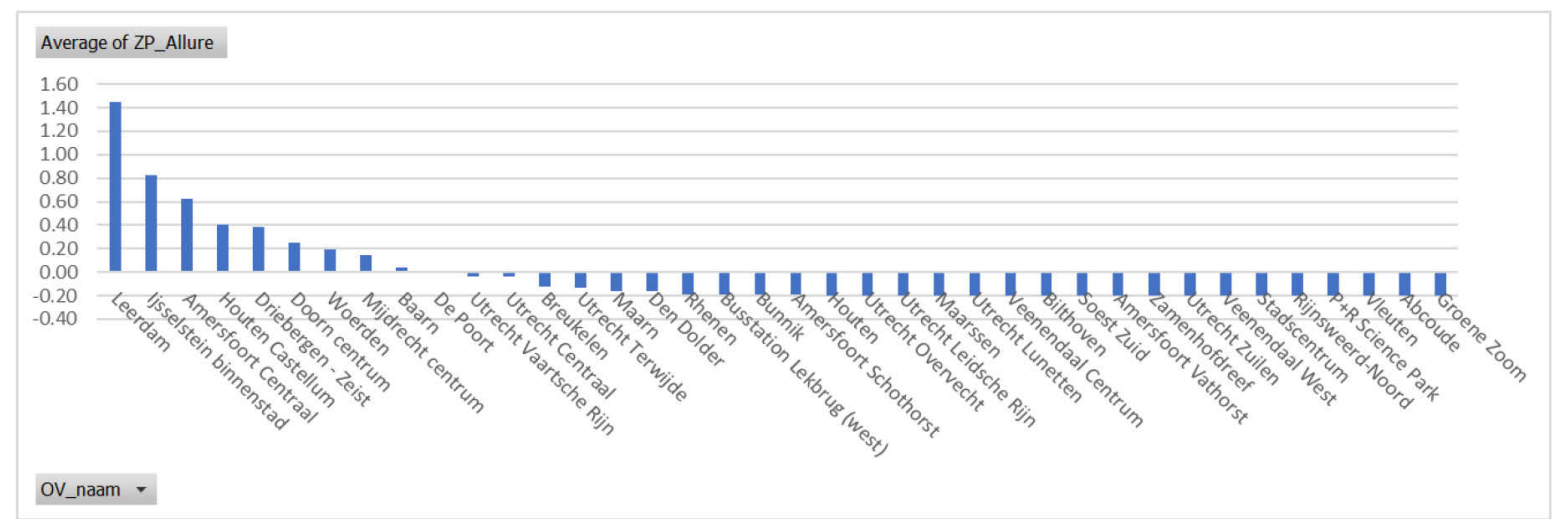

Figuur $8 \quad$ Gemiddelde z-score Allure per Ov-knooppunt

Wanneer de Ov-knooppunten in de provincie Utrecht met elkaar worden vergeleken, dan scoort treinstation Leerdam het hoogst op de hoofdindicator Allure. Dit komt met name door de leisurevoorzieningen rond dit knooppunt en de Rijksmonumenten. Bushalte Groene Zoom in Leusden scoort relatief minder, omdat het niet scoort op de onderscheiden indicatoren.

\section{$8.4 \quad$ Reflectie}

De indicatoren geven een goed beeld van Allure. De verzamelde data lijken ook compleet. Het is niet onlogisch dat loopmogelijkheden niet scoren op deze hoofdindicator, bijvoorbeeld wanneer ze in een woonwijk liggen. De definities van oude gebouwen, boulevard en hoogte panden is evenwel voor discussie vatbaar. 


\section{Veiligheid}

\section{$9.1 \quad$ Inleiding}

De hoofdindicator Veiligheid bestaat uit 23 indicatoren. Het gaat om zowel fysieke veiligheid als om sociale veiligheid bij het lopen. Van 12 indicatoren zijn data gevonden. Eén indicator (Risicogebied) is niet bewerkt, aangezien de ruimtelijke schaal te groot is om onderscheidend te zijn op buurtniveau. Risicogebieden zijn gebieden met mogelijke risicosituaties die kunnen leiden tot rampen en ongevallen, zoals een natuurbrand of ongeval met gevaarlijke stoffen. De 12 indicatoren met data zijn: Parkeerplaats auto's, Maximum snelheid op de rijbaan, Verkeerseilanden, Straatverlichting, Berm (al dan niet groen), Cameratoezicht, Verkeersremmend/drempel, Verkeer afsluitende straat, Een- of meer richtingsverkeer, Verkeerslichten, Drukknoppaal en Zebra. Van zebra's is er maar een gevonden in de gebruikte bestanden als OSM en BGT. Op cameratoezicht na vallen deze indicatoren allemaal onder de fysieke veiligheid. Voor al deze indicatoren (behalve voor snelheid) geldt: hoe meer hoe beter, dus een hogere score op veiligheid.

Van sociale veiligheid zijn weinig data gevonden, zoals voor aanwezigheid van Boa's, Politiesurveillance, Straatcoaches, Buurtpreventie-app, Misdrijf en inbraak op straat en Image van een gebied (kan zowel positief als negatief zijn). Er zijn ook geen data gevonden over Duur voetgangerslicht, Verkeersdrukte, Voetgangersongevallen, Fietsdrukte en Shared spaces.

Door middel van een parkeervak is er een scheiding tussen voetpad en het verkeer op de straat en is dus veiliger. De lengte uit de BGT-parkeervlakken die binnen de $1 \mathrm{~m}$-buffer van een wegdeel ligt, is meegenomen. Uit het NWB-bestand is de snelheid die voor een straat geldt overgenomen die binnen $3 \mathrm{~m}$-buffer van voetpad c.q. fietspad ligt. Het NWB-bestand geeft dan soms meer straten die binnen die buffer vallen. In dat geval is de gemiddelde snelheid berekend. Bij verkeerseilanden zijn alle rijbanen breder dan $7 \mathrm{~m}$ geselecteerd. Alle voet- en fietspaden die binnen een buffer van $12 \mathrm{~m}$ rond een verkeerseiland vallen, krijgen 1 punt. De overige paden die langs straten van meer dan $7 \mathrm{~m}$ liggen, krijgen 0 punten. Rond verkeersdrempels is een buffer getrokken van $5 \mathrm{~m}$. Alle voet- en fietspaden die binnen deze buffer vallen, krijgen 1 punt.

Bij camera's en verlichtingspalen is het aantal gedeeld door de lengte van het wegdeel maal 100 .

Door middel van een berm is er een scheiding tussen voetpad en het verkeer op de straat en is dus veiliger. De lengte is geïnventariseerd uit de BGT 'bermen en groenvoorziening' die binnen de $1 \mathrm{~m}$ buffer van een wegdeel liggen.

Het aantal poller/afsluitpaal/slagboom wordt gesommeerd voor alle voet- en fietspaden die binnen een $5 \mathrm{~m}$-buffer rond poller/afsluitpaal/slagboom liggen.

De data voor de indicator Eenrichting is afkomstig van het NWB, waarbij $\mathrm{H}$ (heen) en $\mathrm{T}$ (terug) is geselecteerd voor eenrichting. Via een buffer van $10 \mathrm{~m}$ rond de lokale rijbaan krijgen alle voet- en fietspaden binnen deze buffer één rijrichtingpunt.

Het aantal verkeerslichten en drukknoppalen wordt gesommeerd voor alle voet- en fietspaden die binnen een $1 \mathrm{~m}$-buffer rond deze verkeerslichten en drukknoppalen liggen.

Rond zebra's is een buffer van 3 m getrokken en de loopmogelijkheden binnen de buffer zijn geselecteerd en krijgen 1 punt. 


\subsection{Buurtscore}

Alleen de gemeente Utrecht scoort op alle indicatoren bij de hoofdindicator Veiligheid. Zeven gemeenten scoren op zes indicatoren, de overige gemeenten tussen de zeven en elf. De gemeente Baarn heeft gemiddeld de meeste parkeervlakken en de gemeente Leusden het minst. In de gemeente Nieuwegein is de gemiddelde snelheid het laagst en in de gemeente Stichtse Vecht het hoogst. Verkeerseilanden komen het meest voor in de gemeente Woerden en het minst in de gemeente Soest. De gemeente Utrechtse Heuvelrug heeft gemiddeld de meeste lantaarnpalen en de gemeente Baarn het minst, maar negen gemeenten hebben geen data hierover. Gemeente Vijfheerenlanden heeft gemiddeld de meeste bermlengte en de gemeente Soest de minste. Gemeente Utrechtse Heuvelrug heeft gemiddeld de meeste camera's en gemeente Bunnik de minste. Vijfheerenlanden doet het gemiddeld ook goed bij de verkeersdrempels en Nieuwegein heeft deze minder. Afsluitpalen komen niet veel voor, slechts in vier gemeenten, met gemeente Utrecht als meest scorende. Eenrichtingsverkeer blijkt in alle gemeenten voor te komen en is daarmee niet onderscheidend. Van verkeerslichten en drukknoppalen zijn ook niet overal data voor. Hier doen gemeente Utrecht en Baarn het goed.

Tabel 16 Gemiddelde score per indicator en z-score bij Veiligheid per gemeente.

\begin{tabular}{|c|c|c|c|c|c|c|c|}
\hline Gemeentenaam & Gemeentecode & P-lengte & Snelheid & Elland & Lantaarn & Bermlengte & Camera \\
\hline Amersfoort & GM0307 & 49.08 & 34.66 & 0.17 & - & 223.04 & - \\
\hline Baarn & GM0308 & 73.37 & 32.63 & 0.18 & 1.85 & 451.96 & - \\
\hline Bunnik & GM0312 & 37.10 & 38.28 & 0.12 & 2.33 & 407.68 & 1.10 \\
\hline Houten & GM0321 & 29.94 & 30.09 & 0.07 & - & 139.55 & - \\
\hline Rhenen & GM0340 & 32.82 & 34.44 & 0.20 & 3.72 & 161.96 & - \\
\hline Soest & GM0342 & 41.63 & 33.42 & 0.02 & - & 60.15 & - \\
\hline Utrecht & GM0344 & 45.16 & 38.73 & 0.19 & 3.93 & 176.44 & 2.70 \\
\hline Veenendaal & GM0345 & 34.88 & 34.23 & 0.14 & - & 106.87 & - \\
\hline Woudenberg & GM0351 & 42.03 & 28.64 & 0.13 & 2.72 & 182.35 & - \\
\hline Woerden & GM0632 & 39.99 & 33.62 & 0.23 & - & 80.82 & - \\
\hline De Ronde Venen & GM0736 & 37.44 & 38.46 & 0.09 & - & 610.59 & 2.16 \\
\hline Utrechtse Heuvelrug & GM1581 & 34.45 & 33.38 & 0.09 & 5.51 & 158.76 & 5.63 \\
\hline Stichtse Vecht & GM1904 & 35.24 & 44.29 & 0.19 & - & 297.08 & 2.29 \\
\hline Vijfheerenlanden & GM1961 & 39.89 & 37.04 & 0.16 & 2.37 & 809.92 & - \\
\hline
\end{tabular}

\begin{tabular}{|c|c|c|c|c|c|c|c|}
\hline Gemeentenaam & Gemeentecode & Drempel & Afsluitpaal & Eenrichting & Verkeerslicht & Drukknop & z-score \\
\hline Amersfoort & GM0307 & 0.32 & - & 1.00 & - & - & 2.37 \\
\hline Baarn & GM0308 & 0.10 & - & 1.00 & 1.33 & 1.67 & 5.15 \\
\hline Bunnik & GM0312 & 0.02 & - & 1.00 & - & - & -4.10 \\
\hline Houten & GM0321 & 0.07 & - & 1.00 & - & - & -2.97 \\
\hline Rhenen & GM0340 & 0.27 & - & 1.00 & 1.00 & 1.00 & -0.28 \\
\hline Soest & GM0342 & 0.17 & - & 1.00 & - & - & -2.95 \\
\hline Utrecht & GM0344 & 0.23 & 3.52 & 1.00 & 2.00 & 1.00 & 2.15 \\
\hline Veenendaal & GM0345 & 0.26 & - & 1.00 & - & - & -0.58 \\
\hline Woudenberg & GM0351 & 0.35 & - & 1.00 & - & - & 1.64 \\
\hline Woerden & GM0632 & 0.16 & - & 1.00 & - & - & 0.64 \\
\hline De Ronde Venen & GM0736 & 0.23 & - & 1.00 & - & 1.00 & -0.89 \\
\hline Utrechtse Heuvelrug & GM1581 & 0.01 & - & 1.00 & - & - & -0.19 \\
\hline Stichtse Vecht & GM1904 & 0.12 & 1.00 & 1.00 & - & - & -2.42 \\
\hline Vijfheerenlanden & GM1961 & 0.40 & 1.80 & 1.00 & 1.00 & - & 2.82 \\
\hline
\end{tabular}


Wanneer alle indicatoren met elkaar worden vergeleken via de z-score, dan laat tabel 16 zien dat de gemeente Baarn in verhouding het hoogst scoort op Veiligheid. Dit komt omdat er van negen van de elf indicatoren data van zijn en omdat er relatief veel parkeervakken zijn, een gemiddeld lage snelheid gehanteerd wordt en er veel bermlengte is om de veiligheid voor voetgangers te vergroten. Gemeente Bunnik scoort van alle gemeenten in de provincie het minst op Veiligheid, ondanks het feit dat er veel data voor de indicatoren gevonden zijn. Bunnik scoort over de hele linie, op de bermlengte na, wat lager.

In tabel 17 staat de z-score van de hoofdindicator Veiligheid van de buurten van de hoogst en laagst scorende gemeente. Deze z-score van een buurt is de som van alle afzonderlijke z-scores van de loopmogelijkheden in die buurt. De z-score van alle buurten is in de separate Excel te vinden.

Tabel 17 Gemiddelde z-score Veiligheid van burten per hoogst en laagst scorende gemeente.

\begin{tabular}{lcccr} 
& \multicolumn{3}{c}{ Hoogste score } & \multicolumn{2}{c}{ Laagste score } \\
\cline { 2 - 5 } Bemeentenaam & Buurtcode & z-score & Burtcode & z-score \\
\hline Buarn & BU03080007 & 2.01 & BU03080201 & -0.42 \\
\hline
\end{tabular}

Van alle buurten in de gemeente Baarn scoort buurt Amaliapark (BU03080007) het best op Veiligheid. In deze buurt zijn er zes loopmogelijkheden die de hoogst z-score hebben. Deze voetpaden hebben allemaal een verkeerseiland en verkeerdrempel en liggen aan rijbaan waar max. $30 \mathrm{~km} / \mathrm{u}$ gereden mag worden. De buurt Verspreide huizen in het zuiden (BU03120009) scoort van alle buurten in Bunnik het laagst. Er zijn veertien loopmogelijkheden in deze buurt die het laagst scoren. Op de rijbanen mag $60 \mathrm{~km} / \mathrm{u}$ gereden worden en er zijn geen bermen, verkeerseilanden of verkeersdrempels.

\subsection{Knooppuntscore openbaar vervoer}

Er is geen verschil in score voor de hoofdindicator Veiligheid tussen bushaltes en treinstations. Wanneer de Ov-knooppunten in de provincie Utrecht met elkaar worden vergeleken, dan scoort treinstation Leerdam het hoogst op de hoofdindicator Veiligheid.

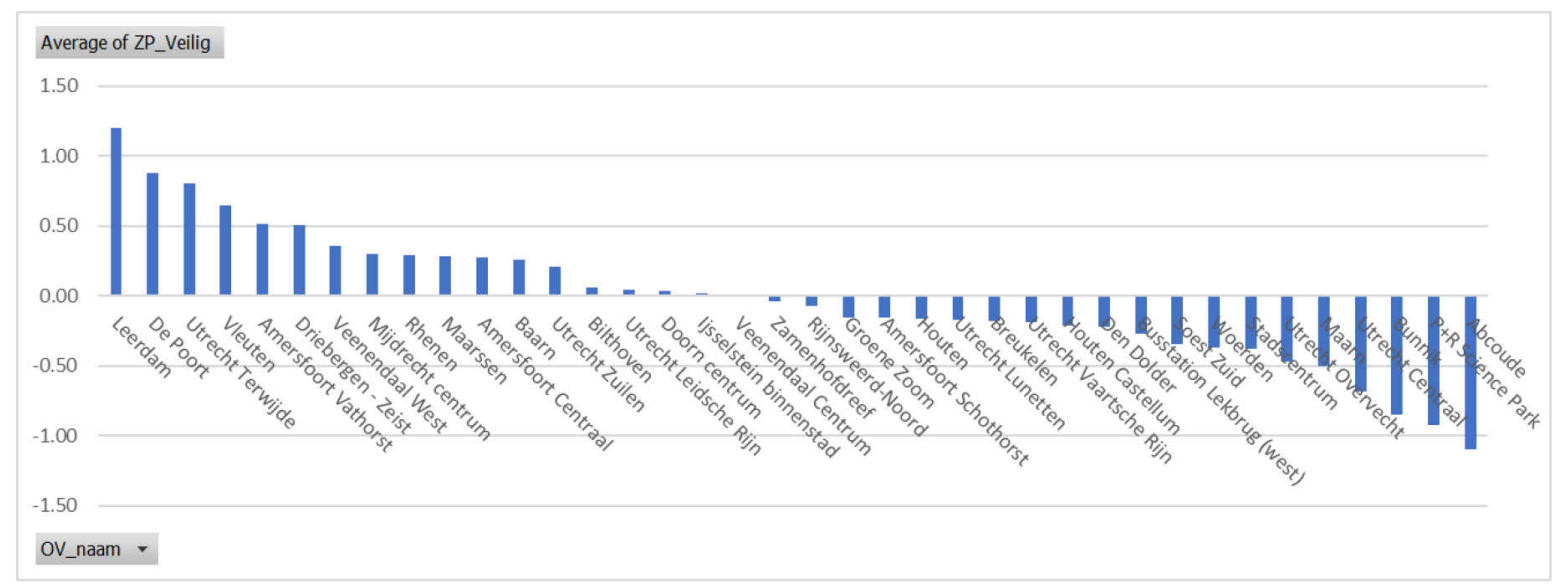

Figur 9 Gemiddelde z-score Veiligheid per Ov-knooppunt.

De hoge score voor Leerdam wordt onder andere veroorzaakt door de vele verkeersdrempels. Vier van de overige acht indicatoren scoren allemaal bovengemiddeld. Treinstation Abcoude doet het minder bij Veiligheid. Er zijn weinig verkeerseilanden en bermlengte en er mag in vergelijking met andere Ovknooppunten redelijk hard gereden worden. Er zijn ook bijna geen eenrichtingswegen. 


\section{$9.4 \quad$ Reflectie}

Voor voetgangers is het belangrijk dat ze veilig kunnen oversteken. Zebra's kunnen daarbij helpen. Data over zebra's zijn niet of nauwelijks aanwezig. Openstreetmap heeft hiervoor wel een code, maar deze is maar één keer ingevuld. Ook data omtrent sociale veiligheid zijn niet goed aanwezig. Data betreffende inbraken en misdrijf zijn er wel, maar die gaan meestal over de huiselijke situatie.

Bij de indicator Verkeerseilanden hebben abusievelijk in de tool alle loopmogelijkheden buiten de buffer 0 punten gekregen. Dus ook voetpaden in een park. Alleen de loopmogelijkheden die langs straten van meer dan $7 \mathrm{~m}$ liggen zonder verkeereiland hadden 0 punten moeten krijgen.

Loopmogelijkheden in de buffer krijgen 1 punt en de overige loopmogelijkheden hadden niet ingevuld mogen worden (no data). Ditzelfde geldt voor verkeersdrempels. Daardoor scoren veel

loopmogelijkheden (zoals een voetpad in een park) ten onrechte minder goed. Wellicht is het beter om het om te draaien. Alle loopmogelijkheden langs rijbanen van meer dan $7 \mathrm{~m}$ en zonder verkeerseiland krijgen 1 punt, die vervolgens negatief meedoet.

Omdat er bij iets minder dan de helft van de indicatoren bij deze hoofdindicator geen data gevonden zijn, is de werking van Veiligheid ook minder. Daarnaast zijn van een aantal indicatoren weinig data gevonden bij enkele gemeenten. Dit geheel maakt dat de hoofdindicator Veiligheid beperkte kwaliteit heeft en is de score een indicatie van veiligheid waarbij verbeteringen van de data nodig zijn.

De hoofdindicator Infrastructuur (hoofdstuk 3) is aanvullend op deze hoofdindicator. Bij infrastructuur wordt een waarde gekoppeld aan de mate van exclusief lopen. Dit heeft ook met veiligheid te maken.

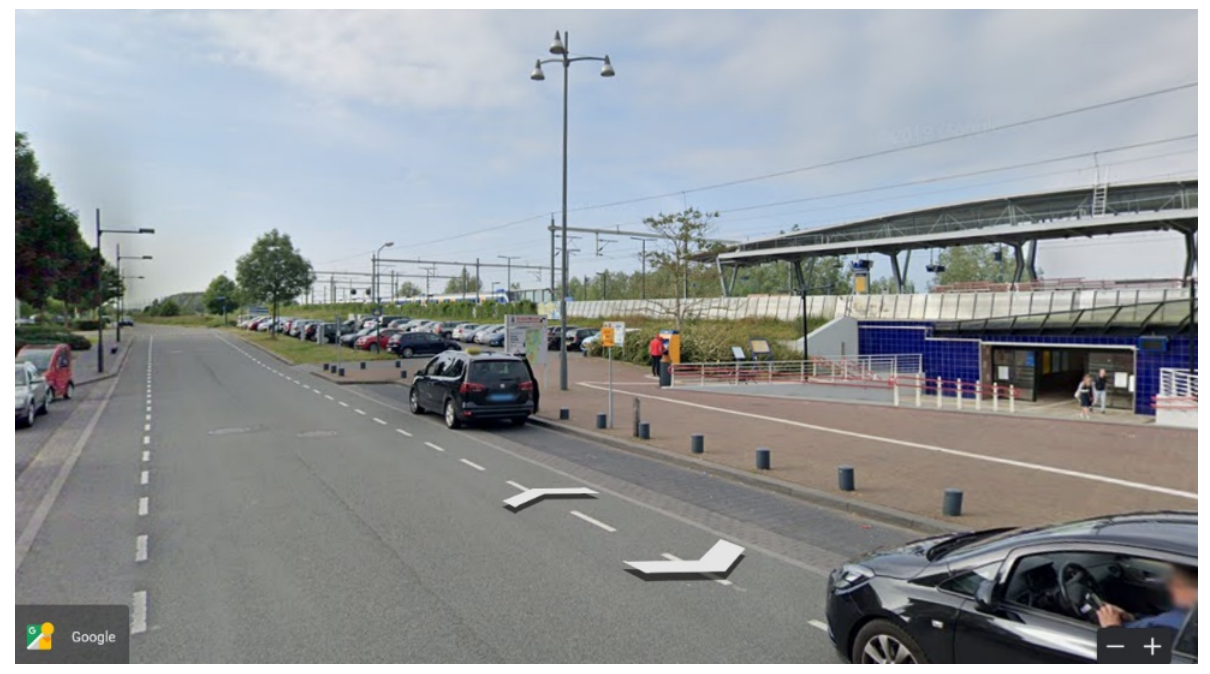

Foto 5 Treinstation Abcoude scoort minder op hoofdindicator Veiligheid. 


\section{Aantrekkelijkheid}

\subsection{Inleiding}

De hoofdindicator Aantrekkelijkheid heeft van alle andere hoofdindicatoren de meeste indicatoren. Maar liefst 55 zijn er in de literatuur gevonden die iets zeggen over de mate van aantrekkelijkheid om ergens te gaan lopen. Van 37 van deze 54 indicatoren zijn data gevonden. Van deze 37 indicatoren zijn er 2 nog niet opgenomen in de tool (biodiversiteit en bebouwingsdichtheid) omdat de data op een ruimer schaalniveau aanwezig zijn en daardoor minder onderscheidend. De volgende 35 indicatoren zijn aan de afzonderlijke loopmogelijkheden gekoppeld.

Beelden, Fonteinen, Herdenkingsmonument, Gevelverdeling, Bomen, Houtwal, groene Berm, voortuin, groene uitstraling, Gemengd landgebruik bestaande uit struiken/haag, begraafplaats, park en plantsoen, recreatiegebied, sportterrein, volkstuin, natuurgebied, bos, Agrarisch terrein en Grasland. Daarnaast zijn er indicatoren die met water te maken hebben zoals beek, rivier, kanaal, sloot, gracht, greppel/droge sloot, vijver en oever. Ten slotte zijn er nog de volgende indicatoren die (soms voor een bepaalde doelgroep) relaties hebben met aantrekkelijkheid zoals Hondenuitlaatplaatsen, bloembak, uitzichtpunt, Afvalbak, beschutting tegen wind en beschutting tegen regen en zon. Al deze indicatoren dragen bij aan een hogers score voor aantrekkelijkheid. De aanwezigheid van Hoogspanningsmasten daarentegen draagt negatief bij.

De loopmogelijkheden in een buffer van $1 \mathrm{~m}$ rond Beelden, Fonteinen en Herdenkingsmonument krijgen de gesommeerde aantallen. $\mathrm{Er}$ is geen herdenkingsmonument in geselecteerde buurten gevonden.

Uit Molster \& Schuit et al. (2021) blijkt dat 15 tot 20 panden per $100 \mathrm{~m}$ (ofwel 0,15-0,2 per m) een ideale gevelverdeling is. Alle loopmogelijkheden van $50 \mathrm{~m}$ of langer zijn geselecteerd. Het aantal panden is gedeeld door de lengte van de loopmogelijkheid. Alle loopmogelijkheden met een score tussen 0,15-2 krijgen 1 punt. De overige 0 punten.

Het bomenregisterbestand uit 2019 is gebruikt. De kruinen van de bomen zijn als polygonen in dit bestand weergegeven. De centroïde van de polygonen is aangemaakt als geldend voor de boomstam dat in een voetpad ligt. Het aantal boomstammen (centroïden) is per loopmogelijkheid opgeteld en gedeeld door de lengte van de loopmogelijkheid keer 100. Hoe meer boomstammen, hoe beter.

Indien een loopmogelijkheid een houtwal of groene berm (uit het bestand BGT, binnen Ondersteunend Wegdeel de "berm en groenvoorziening" geselecteerd) heeft binnen een buffer van 5 m, krijgt de loopmogelijkheid een punt.

Uit onderzoek (Van den Berg et al., 2002) blijkt dat de beleving van diverse watertypen verschillend is. Kanalen en sloten worden anders beleefd dan beken, rivieren en grachten. Vandaar dat alle watertypen apart zijn opgenomen. Indien een loopmogelijkheid aan een beek, rivier, kanaal, sloot, gracht, vijvers, greppel/droge en oevers ligt binnen een buffer van $10 \mathrm{~m}$, krijgt de loopmogelijkheid een punt. In het onderzoeksgebied heeft de BGT geen data voor beken en kanalen.

Voortuinen van panden worden in de BGT beschouwd als onderdeel van het erf (onbegroeid terreindeel). Dit wil echter niet zeggen dat de voortuin ook altijd groen is. Sommige inwoners prefereren een verharde voortuin. In hoeverre de voortuin daadwerkelijk groen is, valt binnen het tijdsbestek van dit onderzoek niet te operationaliseren. De lengte van een loopmogelijkheid met deze indicator binnen een $5 \mathrm{~m}$-buffer is berekend.

De indicator Gemengd Landgebruik is een sommatie van tien afzonderlijke landgebruiksvormen, namelijk Hagen uit het BGT-bestand en uit het CBS-Bodemstatistiek komen de indicatoren Begraafplaats, Park en plantsoen, Recreatiegebied, Sportterrein, Volkstuin, Natuurgebied, Bos, 
Agrarisch terrein en Grasland. Indien een dergelijke indicator binnen een buffer van $5 \mathrm{~m}$ van een loopmogelijkheid voorkomt, krijgt het een punt. De punten worden opgeteld en door het maximale aantal van 10 gedeeld.

De indicator Groene uitstraling is ook gebaseerd op het bomenregisterbestand. Via remote sensing is het groen in rasters van $10 \times 10$ m opgenomen. Het verschil met de indicator Bomen is dat nu ook het groen op particulier terrein is meegenomen dat voor een groene uitstraling zorgt. De rasters zijn gekoppeld aan de loopmogelijkheden. Vervolgens is dit getal gedeeld door de lengte van de loopmogelijkheid. Het kan dus zijn dat een raster over meer loopmogelijkheden valt, bijvoorbeeld een straat met aan een kant een voetpad met bomen en aan het tegenoverliggende voetpad geen bomen. Toch krijgen beide voetpaden (en straat) dezelfde waarden, omdat ze in hetzelfde raster liggen. Dit noemen we de groene uitstraling.

Alle loopmogelijkheden die liggen in een buffer van $1 \mathrm{~m}$ rond hondenuitlaatplaatsen, hoogspanningsmast, afvalbak, bloembak en uitzichtpunt krijgen de sommatie van het aantal. Hoogspanningsmasten scoren hierbij negatief op de score. Er zijn in het onderzoeksgebied geen hondenuitlaatplaatsen geregistreerd.

Er is een kans op windhinder bij gebouwen die hoger zijn dan $15 \mathrm{~m}$. Al deze gebouwen zijn geteld en toegewezen aan de loopmogelijkheid die binnen een buffer van $5 \mathrm{~m}$ van loopmogelijkheid liggen. Windhinder scoort negatief op de score.

Voor het bepalen van beschutting zijn bomen, luifels en (Ov-)haltes genomen. Deze worden geteld binnen $3 \mathrm{~m}$ afstand van een loopmogelijkheid.

Van de volgende indicatoren zijn geen data gevonden: Groene schoolplein, Waterspeelplaats, Aangename geuren, Groene gevel, Groen in plaats van een steen aan de straat (Operatie Steenbreek), Plezierige weersomstandigheden, Wadi, Straatverkoop/stalletjes, Landmarks, Onderhoud groen. Al deze indicatoren werken positief op aantrekkelijkheid. Negatief scoren de volgende indicatoren waar geen data voor gevonden zijn: Onbebouwd terrein, Hondenpoep, Zwerfhonden, Bedelaars/zwervers/drugsverkopers, Vandalisme, Graffiti, Hangjongeren en Afval op straat.

\subsection{Buurtscore}

Alleen de gemeente Utrecht scoort op alle indicatoren bij de hoofdindicator Aantrekkelijkheid. Deze gemeente scoort relatief goed op aanwezigheid van beelden, maar gemeente IJsselstein doet het nog iets beter op deze indicator. Fonteinen komen niet veel voor. De gemeente Woerden heeft de beste gevelverdeling. Gemeente Soest heeft gemiddeld de meeste bomen en De Bilt gemiddeld de meeste houtwallen en groene bermen. Water komt gemiddeld het meest voor in gemeente Stichtse Vecht en bij oevers scoort gemeente Leusden het best en deze gemeente scoort ook het best bij gemengd landgebruik. 
Tabel 18 Gemiddelde score per indicator en z-score bij Aantrekkelijkheid per gemeente.

\begin{tabular}{|c|c|c|c|c|c|c|c|c|c|}
\hline Gemeentenaam & Gemeentecode & Beelden & Fontein & Gevel & Boom & Houtwal & Berm & Water & Oever \\
\hline Amersfoort & GM0307 & 1.00 & - & 0.10 & 5.35 & 0.0000 & 1.64 & 0.28 & 0.26 \\
\hline Baarn & GM0308 & 1.00 & 1.00 & 0.09 & 3.64 & 0.0000 & 2.69 & 0.03 & 0.01 \\
\hline Bunnik & GM0312 & 1.00 & 1.00 & 0.08 & 2.91 & 0.0000 & 2.13 & 0.22 & 0.18 \\
\hline Houten & GM0321 & 1.00 & 1.00 & 0.08 & 5.32 & 0.0000 & 1.00 & 0.15 & 0.12 \\
\hline Rhenen & GM0340 & - & - & 0.05 & 2.50 & 0.0048 & 1.74 & 0.01 & 0.03 \\
\hline Soest & GM0342 & - & - & 0.06 & 7.93 & 0.0008 & 1.58 & 0.01 & 0.01 \\
\hline Utrecht & GM0344 & 1.25 & 1.00 & 0.10 & 2.86 & 0.0000 & 1.85 & 0.20 & 0.17 \\
\hline Veenendaal & GM0345 & - & - & 0.07 & 6.77 & 0.0010 & 1.00 & 0.12 & 0.14 \\
\hline Nieuwegein & GM0356 & - & 1.00 & 0.10 & 3.84 & 0.0000 & 1.93 & 0.23 & 0.23 \\
\hline Woerden & GM0632 & 1.00 & 1.00 & 0.12 & - & 0.0000 & 1.00 & 0.34 & 0.09 \\
\hline De Ronde Venen & GM0736 & - & - & 0.05 & 3.38 & 0.0000 & 2.51 & 0.40 & 0.24 \\
\hline Utrechtse Heuvelrug & GM1581 & 1.00 & - & 0.10 & 6.10 & 0.0016 & 1.89 & 0.05 & 0.03 \\
\hline Stichtse Vecht & GM1904 & - & - & 0.05 & 3.66 & 0.0000 & 1.84 & 0.50 & 0.25 \\
\hline Vijfheerenlanden & GM1961 & 1.00 & - & 0.10 & 3.89 & 0.0011 & 2.30 & 0.26 & 0.09 \\
\hline
\end{tabular}

Gemeente Baarn heeft de meeste gemiddelde voortuinlengte en ook de meeste groene uitstraling en gemiddeld de meeste afvalbakken. Hoogspanningsmasten en bloembakken komen maar sporadisch voor in de gebruikte bestanden. Uitzichtpunten zijn alleen genoteerd in Amersfoort, Rhenen en Utrecht. De kans op windhinder is het grootst in de gemeente Utrecht en de gemeente Stichtse Vecht biedt de meeste beschutting tegen zon en regen.

Tabel 18 (vervolg) Gemiddelde score per indicator en z-score bij Aantrekkelijkheid per gemeente.

\begin{tabular}{lllllllll} 
Gemeentenaam & Gemeentecode & Voortuin & Menging & Uitstraling & $\begin{array}{r}\text { Hoogspan- } \\
\text { ning }\end{array}$ & Afval & Bloembak \\
Amersfoort & GM0307 & 61.00 & 0.11 & 0.52 & 0.00 & 1.29 & 0.00 \\
\hline Baarn & GM0308 & 98.20 & 0.08 & 4.31 & 0.00 & 2.00 & 0.00 \\
\hline De Bilt & GM0310 & 66.34 & 0.11 & 3.21 & 0.00 & 1.14 & 0.00 \\
\hline Bunnik & GM0312 & 43.62 & 0.11 & 0.92 & 0.00 & 1.23 & 0.00 \\
\hline Houten & GM0321 & 28.96 & 0.11 & 0.24 & 0.00 & 1.05 & 0.00 \\
\hline Leusden & GM0327 & 34.81 & 0.15 & 0.75 & 0.00 & - & 0.00 \\
\hline Rhenen & GM0340 & 53.83 & 0.10 & 0.57 & 0.00 & 1.00 & 0.00 \\
\hline Soest & GM0342 & 69.58 & 0.10 & 2.55 & 0.00 & - & 0.00 \\
\hline Utrecht & GM0344 & 44.05 & 0.10 & 0.55 & 0.00 & 1.39 & 0.00 \\
\hline Veenendaal & GM0345 & 50.13 & 0.13 & 0.52 & 0.01 & 1.40 & 0.00 \\
\hline Woudenberg & GM0351 & 62.03 & 0.12 & 0.29 & 0.00 & 1.00 & 0.00 \\
\hline IJsselstein & GM0353 & 46.75 & 0.11 & & 0.00 & 1.00 & 0.00 \\
\hline Zeist & GM0355 & 67.22 & 0.13 & 2.16 & 0.00 & 1.00 & 0.00 \\
\hline Nieuwegein & GM0356 & 49.04 & 0.09 & 1.17 & 0.00 & 1.00 & 0.02 \\
\hline Woerden & GM0632 & 39.17 & 0.09 & 0.47 & 0.00 & 1.00 & 0.00 \\
\hline De Ronde Venen & GM0736 & 43.74 & 0.10 & 0.50 & 0.00 & 1.11 & 0.00 \\
\hline Utrechtse Heuvelrug & GM1581 & 38.50 & 0.11 & 3.69 & 0.00 & 1.17 & 0.00 \\
\hline Stichtse Vecht & GM1904 & 28.74 & 0.09 & 0.99 & 0.00 & - & 0.00 \\
\hline Vijfheerenlanden & GM1961 & 50.36 & 0.09 & 1.18 & 0.00 & 1.09 & 0.00 \\
\hline
\end{tabular}




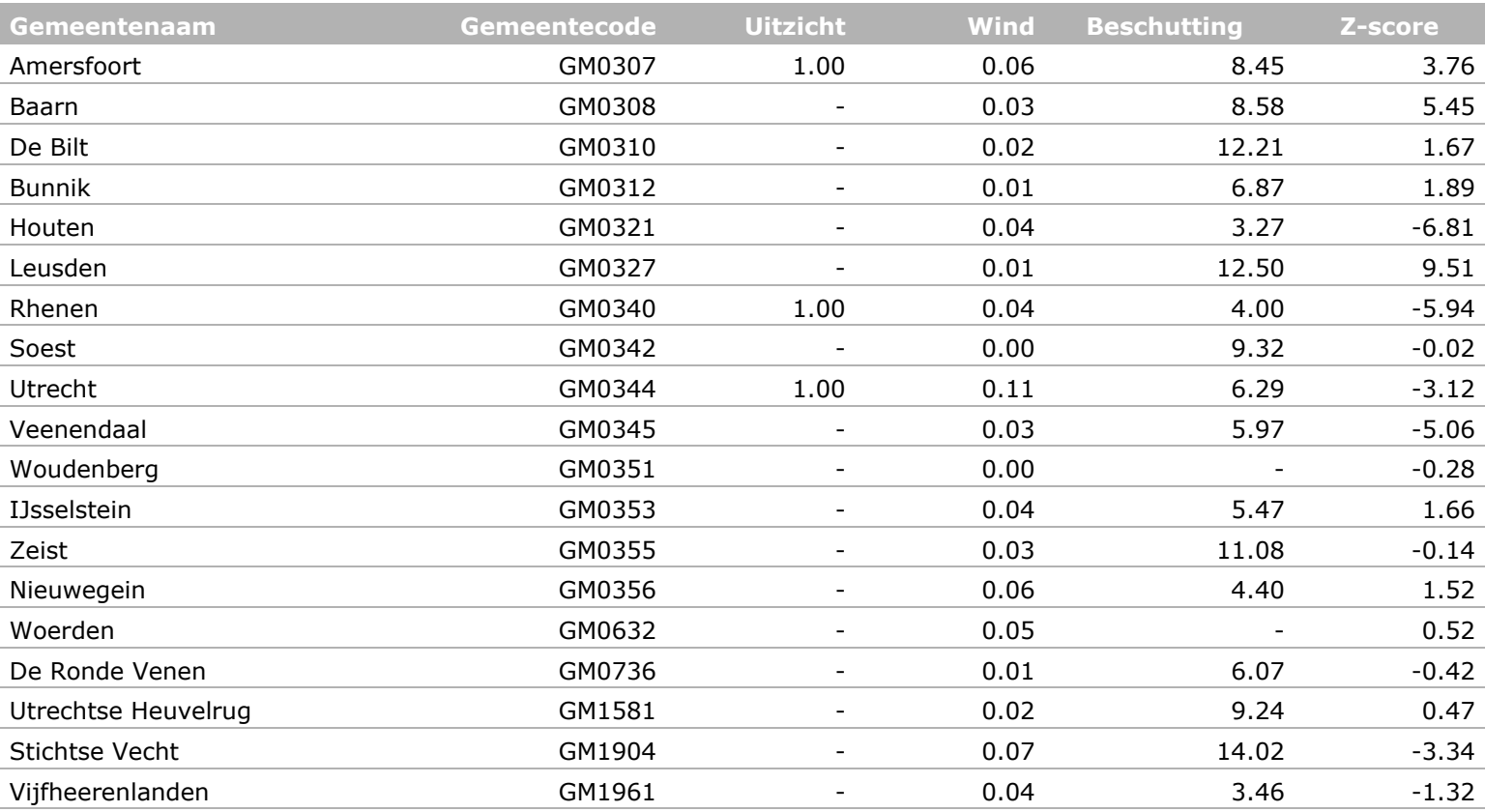

Wanneer alle indicatoren met elkaar worden vergeleken via de z-score, dan laat tabel 18 zien dat de gemeente Leusden in verhouding het best scoort op aantrekkelijkheid. Dit komt met name door de hoeveelheid bomen aan de loopmogelijkheden, de oevers, het gemengd landgebruik en de beschutting.

Gemeente Houten scoort in verhouding het laagst op aantrekkelijkheid. Er zijn relatief weinig houtwallen, groene bermen en voortuinen. Het scoort ook relatief laag op een groene uitstraling en er is enige kans op windhinder en relatief weinig beschutting.

In tabel 19 staat de z-score van de hoofdindicator Aantrekkelijkheid van de buurten van de hoogst en laagst scorende gemeente. Deze z-score van een buurt is de som van alle afzonderlijke z-scores van de loopmogelijkheden in die buurt. De z-score van alle buurten is in de separate Excel te vinden.

Tabel 19 Gemiddelde z-score Aantrekkelijkheid van buurten per hoogst en laagst scorende gemeente.

\begin{tabular}{|c|c|c|c|c|}
\hline \multirow[t]{2}{*}{ Gemeentenaam } & \multicolumn{2}{|c|}{ Hoogste score } & \multicolumn{2}{|c|}{ Laagste score } \\
\hline & Buurtcode & z-score & Buurtcode & z-score \\
\hline Leusden & BU03270109 & 1.19 & BU03270108 & -1.57 \\
\hline
\end{tabular}

Van alle buurten in de gemeente Leusden scoort de buurt Buitengebied Leusden-Centrum-West (BU03270109) het best op aantrekkelijkheid. Een 2,5 $\mathrm{m}$ lang voetpad aan de Heiligenbergerbeek in het Lockhorsterbos scoort in deze buurt het hoogst.

De buurt Centrum-West (BU03211120 in Houten scoort in deze gemeente het minst. Binnen deze buurt heeft een voetpad op de parkeerplaats achter het gemeentehuis de laagste score.

\subsection{Knooppuntscore openbaar vervoer}

$\mathrm{Er}$ is verschil in score voor de hoofdindicator Aantrekkelijkheid tussen bushaltes en treinstations. De loopmogelijkheden rond bushaltes in de provincie Utrecht scoren met een gemiddelde z-score van 0,27 beter op de hoofdindicator Aantrekkelijkheid dan treinstations $(-0,08)$. Rond bushaltes is iets meer water en daardoor meer oevers, meer groene bermen, meer bloembakken en beschutting maar ook meer kans op windhinder. Rond treinstations zijn meer bomen, meer voortuinen en er is een groenere uitstraling. 
Wanneer de Ov-knooppunten in de provincie Utrecht met elkaar worden vergeleken, scoort bushalte De Groene Zoom in Leusden het hoogst op de hoofdindicator Aantrekkelijkheid.

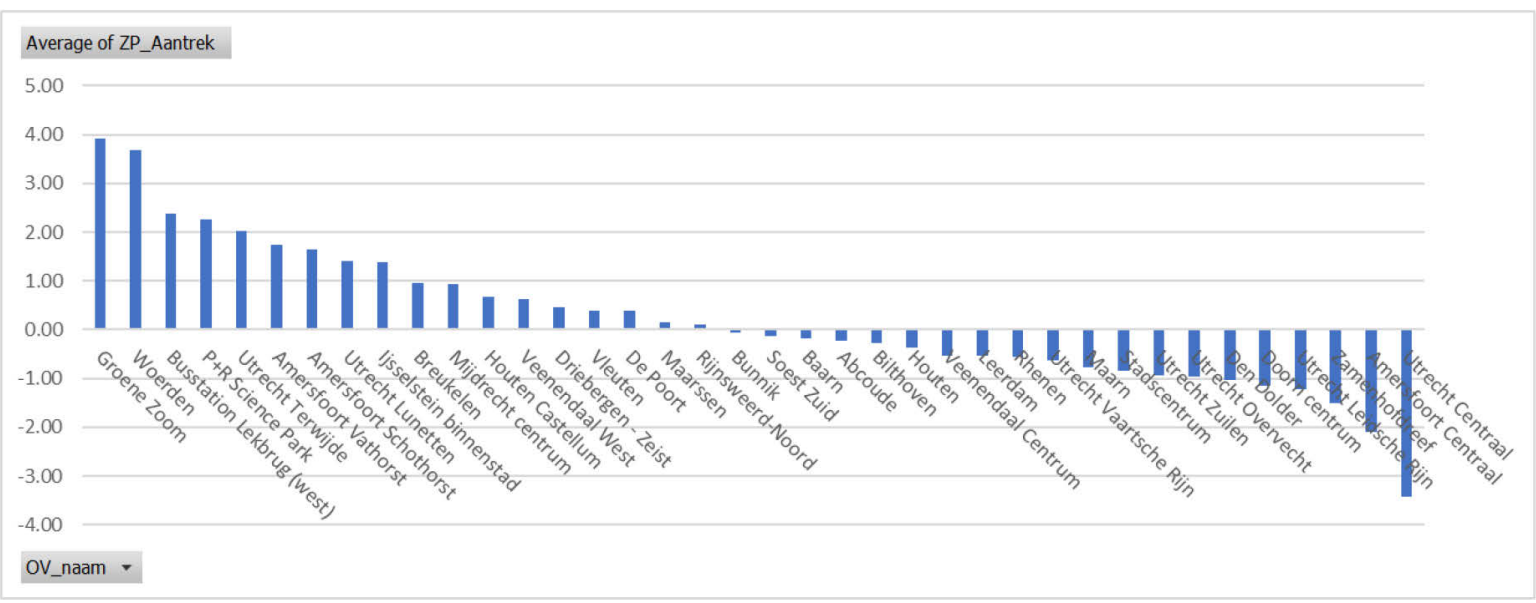

Figuur 10 Gemiddelde z-score Aantrekkelijkheid per Ov-knooppunt.

Dit komt met name door het relatief veel voorkomen van groen en water rond deze bushalte in vergelijking met andere Ov-knooppunten in de provincie. Utrecht Centraal Station scoort in verhouding het laagst op aantrekkelijkheid. Groen is beperkt aanwezig.

\subsection{Reflectie}

Er is enige overlap tussen bomen, gemengd landgebruik en groene uitstraling. Gemengd landgebruik heeft ook bos, park en plantsoen. Het verschil met bomen is dat bij de indicator Bomen de aantallen op de loopmogelijkheden liggen en bos ligt naast een loopmogelijkheid. In bossen zijn vaak onverharde voetpaden waar dus geen bomen op staan. Bij groene uitstraling gaat het ook om bomen die op particulier terrein staan. Bij de GIS-bewerking voor bomen is er echter iets misgegaan, want de gemeenten Woerden en Woudenberg scoren hier niet op, terwijl er wel bomen staan.

Deze hoofdindicator bevat veel indicatoren waarbij er voor meer dan de helft data zijn gevonden. De data lijken, op een enkeling na, ook redelijk ingevuld. Dit maakt dat de resultaten een goede indicatie zijn voor deze hoofdindicator.

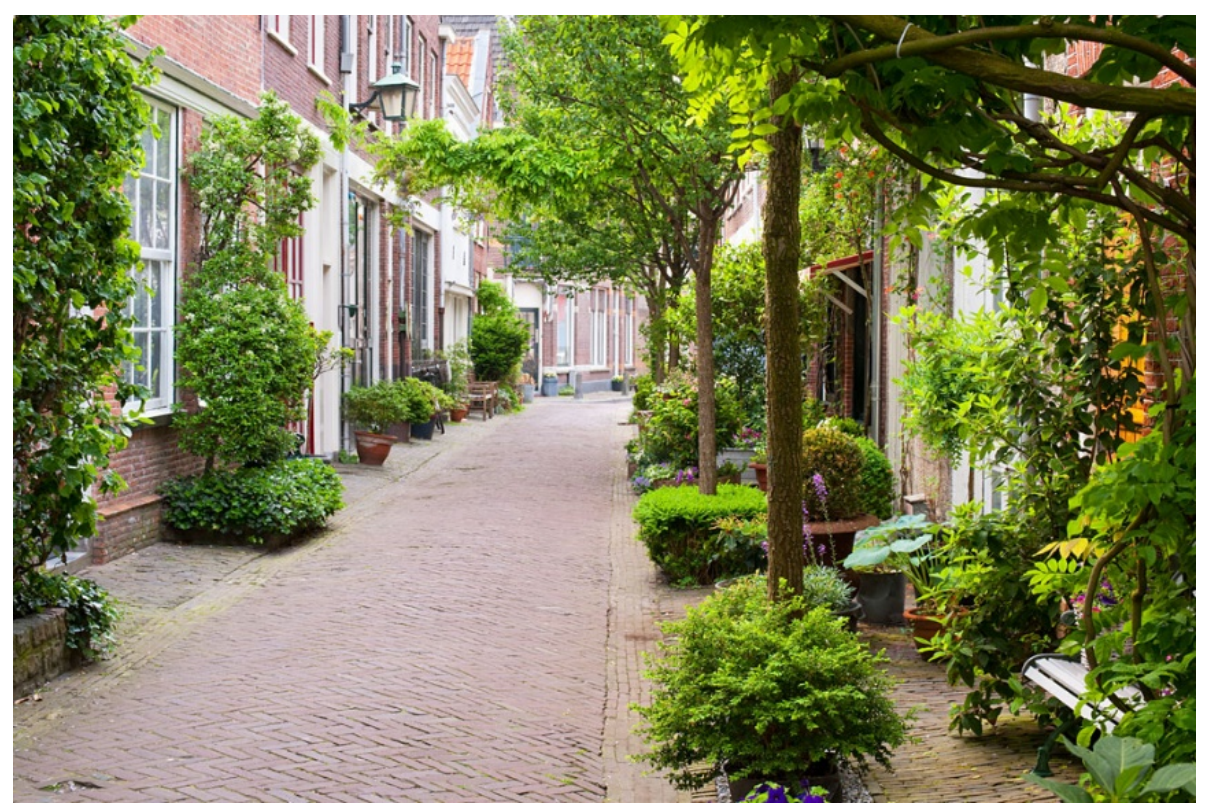

Foto 6

Groene uitstraling is een van de indicatoren bij de hoofdindicator Aantrekkelijkheid. 


\section{Bewegwijzering}

\section{$11.1 \quad$ Inleiding}

Deze hoofdindicator bestaat uit vijf indicatoren waarbij voor vier ervan data zijn gevonden. Dit zijn de indicatoren Toeristische informatie, Wegwijzers, Straatnaambordje en Overzichtskaart. Hierbij geldt dat hoe hoger de aantallen, hoe hoger de score. Daarbij is een buffer van $1 \mathrm{~m}$ aangehouden van deze indicatoren. Het aantal is opgeteld voor alle loopmogelijkheden in deze buffer. Wel moet worden opgemerkt dat ze slecht zijn ingevuld. Van de indicator Overzichtskaart zijn geen data ingevuld.

Van de indicator Wandelroutes zijn in het tijdsbestek van dit onderzoek geen directe data uitgewerkt. De gemarkeerde wandelroutes zijn er wel, maar vragen een extra inspanning om die in GIS te zetten.

\subsection{Buurtscore}

De gemeenten Nieuwegein en Vijfheerenlanden zijn de enige twee gemeenten waar voor alle drie de indicatoren data zijn ingevuld. Gemeente Utrecht scoort relatief het best op toeristische info en wegwijzers. Gemeente Vijfheerenlanden scoort het best op straatnaambordjes, maar daarvan zijn in slechts drie gemeenten data gevonden (tabel 20).

Tabel 20 Gemiddelde score per indicator en z-score bij Bewegwijzering per gemeente.

\begin{tabular}{|c|c|c|c|c|c|}
\hline Gemeentenaam & Gemeentecode & Toeristische Info & Straatnaam & Wegwijzers & Z-score \\
\hline Amersfoort & GM0307 & 1.00 & - & 1.39 & -0.59 \\
\hline Baarn & GM0308 & - & 1.29 & 1.20 & -0.24 \\
\hline Bunnik & GM0312 & 1.08 & - & 7.61 & 5.02 \\
\hline Houten & GM0321 & 1.00 & - & 1.37 & -0.61 \\
\hline Rhenen & GM0340 & - & - & 1.71 & 0.07 \\
\hline Soest & GM0342 & - & - & 1.30 & -0.21 \\
\hline Utrecht & GM0344 & 1.20 & - & 2.00 & 3.20 \\
\hline Veenendaal & GM0345 & 1.00 & - & 1.00 & -0.86 \\
\hline Nieuwegein & GM0356 & 1.00 & 1.05 & 1.00 & -1.88 \\
\hline Woerden & GM0632 & 1.00 & - & 1.50 & -0.52 \\
\hline De Ronde Venen & GM0736 & 1.00 & - & 1.40 & -0.59 \\
\hline Utrechtse Heuvelrug & GM1581 & 1.00 & - & 1.59 & -0.46 \\
\hline Stichtse Vecht & GM1904 & 1.00 & - & 1.02 & -0.84 \\
\hline Vijfheerenlanden & GM1961 & 1.00 & 1.50 & 1.00 & 0.12 \\
\hline
\end{tabular}

Wanneer alle indicatoren met elkaar worden vergeleken via de z-score, dan laat tabel 20 zien dat de gemeente Bunnik in verhouding het best scoort op deze hoofdindicator. Dit komt met name door de wegwijzers. Maar in Bunnik hebben twee loopmogelijkheden zeventien wegwijzers volgens de berekening en dat lijkt vrij onrealistisch. Gemeente Nieuwegein scoort relatief het slechtst, ondanks of juist dankzij de ingevulde indicatoren. Als er niets wordt ingevuld, krijgt een loopmogelijkheid een $z$-score van 0 . Als er wel iets is ingevuld, wordt dat in de $z$-score vergeleken met hogere waarden, waardoor er een negatief getal uitkomt. 
In tabel 21 staat de z-score van de hoofdindicator Bewegwijzering van de buurten van de hoogst en laagst scorende gemeente. Deze z-score van een buurt is de som van alle afzonderlijke z-scores van de loopmogelijkheden in die buurt. De z-score van alle buurten is in de separate Excel te vinden.

Tabel 21 Gemiddelde z-score Bewegwijzering van buurten per hoogst en laagst scorende gemeente.

\begin{tabular}{|c|c|c|c|c|}
\hline \multirow[t]{2}{*}{ Gemeentenaam } & \multicolumn{2}{|c|}{ Hoogste score } & \multicolumn{2}{|c|}{ Laagste score } \\
\hline & Buurtcode & z-score & Buurtcode & z-score \\
\hline Bunnik & BU03120000 & 0.08 & BU03120009 & -0.68 \\
\hline
\end{tabular}

De gemeente Bunnik heeft in dit onderzoek maar twee buurten en de buurt Bunnik (BU03120000) scoort dan het best. Binnen deze buurt heeft een (onterecht opgenomen) oprit naar een provinciale weg de hoogste score door de bewegwijzering. De buurt Doorslag (BU03560500) in de gemeente Nieuwegein scoort van alle buurten in deze gemeente het minst. Er zijn veertien loopmogelijkheden in deze buurt die laag scoren op deze hoofdindicator. De data laten een beperkte hoeveelheid straatnaambordjes zien.

\subsection{Knooppuntscore openbaar vervoer}

De loopmogelijkheden rond treinstations in de provincie Utrecht scoren met een gemiddelde z-score van 0,07 beter op de hoofdindicator Bewegwijzering dan bushaltes $(-0,22)$. De treinstations doen het over de hele linie beter dan bushaltes, maar vooral op wegwijzers en straatnaambordje.

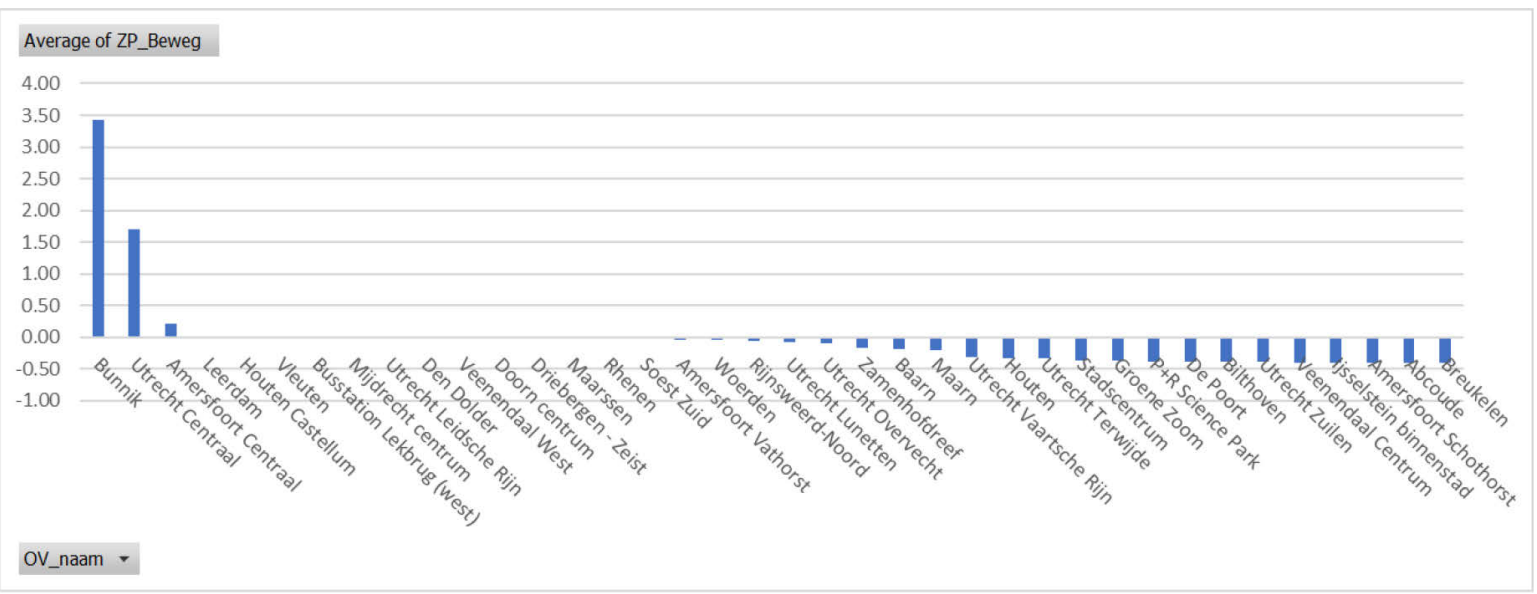

Figuur 11 Gemiddelde z-score Aantrekkelijkheid per Ov-knooppunt.

Treinstation Bunnik scoort van alle Ov-knooppunten in de provincie het hoogst op bewegwijzering. Dit komt met name door de wegwijzers. Treinstation Breukelen scoort relatief het laagst door juist een beperkt aantal wegwijzers.

\subsection{Reflectie}

Deze hoofdindicator is slecht gevuld en heeft daarom maar een beperkte werking. Bovendien lijkt er bij de bewegwijzering een fout te zijn gemaakt in de bufferafstand. Twee loopmogelijkheden hebben zeventien wegwijzers volgens de berekening en dat lijkt vrij onrealistisch.

Als er bij een loopmogelijkheid voor een indicator een waarde is ingevuld, wordt dat in de z-score vergeleken met hogere waarden, waardoor er een negatief getal uitkomt. Is er niks ingevuld bij een loopmogelijkheid, dan krijgt die een waarde 0 . Dat is hoger dan de negatieve waarde wanneer er wel iets is ingevuld, maar in verhouding minder dan bij andere loopmogelijkheden. Bij deze hoofdindicator komt dat veel voor en dat is eigenlijk niet wenselijk. 


\section{Loopscore}

\section{$12.1 \quad$ Inleiding}

Alle hoofdindicatoren zijn bij elkaar opgeteld om een loopscore te genereren. Daarbij wegen de hoofdindicatoren allemaal even zwaar. In dit hoofdstuk zijn twee soorten loopscores. Paragraaf 12.2 geeft de loopscores van de afzonderlijke loopmogelijkheden in buurten per gemeente. De loopmogelijkheden zijn in die gemeente met elkaar vergeleken. Daarmee kan een gemeente direct zien welke loopmogelijkheid goed dan wel minder goed scoort in de gemeente en hier gericht beleid op gaan voeren. Als voorbeeld wordt in paragraaf 12.4 een handelingsperspectief beschreven van de gemeente Utrecht.

In paragraaf 12.3 zijn de loopscores van de loopmogelijkheden rond Ov-knooppunten gepresenteerd. Hierbij worden de loopmogelijkheden met de hele provincie vergeleken en is duidelijk welk Ovknooppunt in de provincie goed dan wel minder goed scoort.

\subsection{Loopscore per gemeente}

De gemiddelde loopscore is berekend door de afzonderlijke z-scores per hoofdindicator op te tellen. De loopscore van de individuele loopmogelijkheden loopt uiteen van $-76,6$ tot 113,8 . Van de totale lengte aan loopmogelijkheden heeft $58 \%$ een positieve z-score. De mate van beloopbaarheid is bepaald door de loopmogelijkheden te verdelen in klassen. Een score van 1 of meer wordt beschouwd als hoge beloopbaarheid en een score van -1 of minder wordt beschouwd als lage beloopbaarheid. Een scoretussen 1 en -1 is dan gemiddeld.

Tabel 22 Gemiddelde Loopscore en mate van beloopbaarheid (\%) van loopmogelijkheden $(N)$ per gemeente.

\begin{tabular}{|c|c|c|c|c|c|c|}
\hline \multirow[t]{2}{*}{ Gemeentenaam } & \multirow[t]{2}{*}{ Gemeentecode } & \multirow[t]{2}{*}{ Loopscore } & \multicolumn{4}{|c|}{ Beloopbaarheid } \\
\hline & & & Hoog & Gemiddeld & Laag & N \\
\hline Utrecht & GM0344 & 15.29 & 41.7 & 14.2 & 44.1 & 19099 \\
\hline IJsselstein & GM0353 & 10.66 & 42.1 & 13.6 & 44.3 & 1471 \\
\hline Leusden & GM0327 & 7.14 & 40.2 & 11.7 & 48 & 1183 \\
\hline Woudenberg & GM0351 & 6.56 & 43 & 13.4 & 43.7 & 1198 \\
\hline Baarn & GM0308 & 3.01 & 36.1 & 14.4 & 49.5 & 877 \\
\hline Vijfheerenlanden & GM1961 & 2.93 & 38.3 & 15 & 46.6 & 5708 \\
\hline Bunnik & GM0312 & 0.91 & 45 & 10.1 & 44.9 & 2108 \\
\hline Zeist & GM0355 & -6.06 & 32.2 & 18.1 & 49.7 & 1368 \\
\hline Soest & GM0342 & -6.17 & 41.4 & 17.4 & 41.3 & 1318 \\
\hline Utrechtse Heuvelrug & GM1581 & -6.57 & 39.8 & 17.3 & 43 & 4286 \\
\hline De Bilt & GM0310 & -7.61 & 34.6 & 18.4 & 47 & 3601 \\
\hline Rhenen & GM0340 & -11.62 & 45.5 & 12.4 & 42.1 & 627 \\
\hline Veenendaal & GM0345 & -12.03 & 36.2 & 14.1 & 49.7 & 4199 \\
\hline Houten & GM0321 & -12.62 & 37.9 & 12.3 & 49.7 & 3687 \\
\hline
\end{tabular}


Uit tabel 22 blijkt dat de elf van de negentien gemeenten een positieve loopscore hebben en acht een negatieve. De gemeente Utrecht heeft de hoogste loopscore en gemeente Houten de laagste. Toch hebben de buurten in de gemeente Utrecht meer loopmogelijkheden met een lage beloopbaarheid dan loopmogelijkheden met een hoge beloopbaarheid, al is het verschil niet erg groot. Voor dit onderzoek zijn in de gemeente Utrecht 31 buurten meegenomen met in totaal circa 19.000 loopmogelijkheden die met elkaar $1050 \mathrm{~km}$ lang zijn, waarvan $69 \%$ uit voetpaden bestaat.

In de gemeente Houten heeft bijna de helft van de buurten een lage beloopbaarheid. Dit is opvallend, aangezien Houten wel bekendstaat als fietsstad.

In de gemeente Stichtse Vecht hebben de meeste buurten een hoge beloopbaarheid. Toch is de totale loopscore in deze gemeente niet erg hoog, maar wel positief.

Tabel 23 geeft aan hoe de individuele hoofdindicatoren scoren met hun z-score. Deze z-score is berekend door per gemeente de loopmogelijkheden met elkaar te vergelijken. De hoofdindicatoren zijn dus allemaal even zwaar gewogen en dan valt op dat de hoofdindicator Directheid van voorzieningen sterk bepalend is.

Tabel 23 Gemiddelde z-score van alle hoofdindicatoren per gemeente.

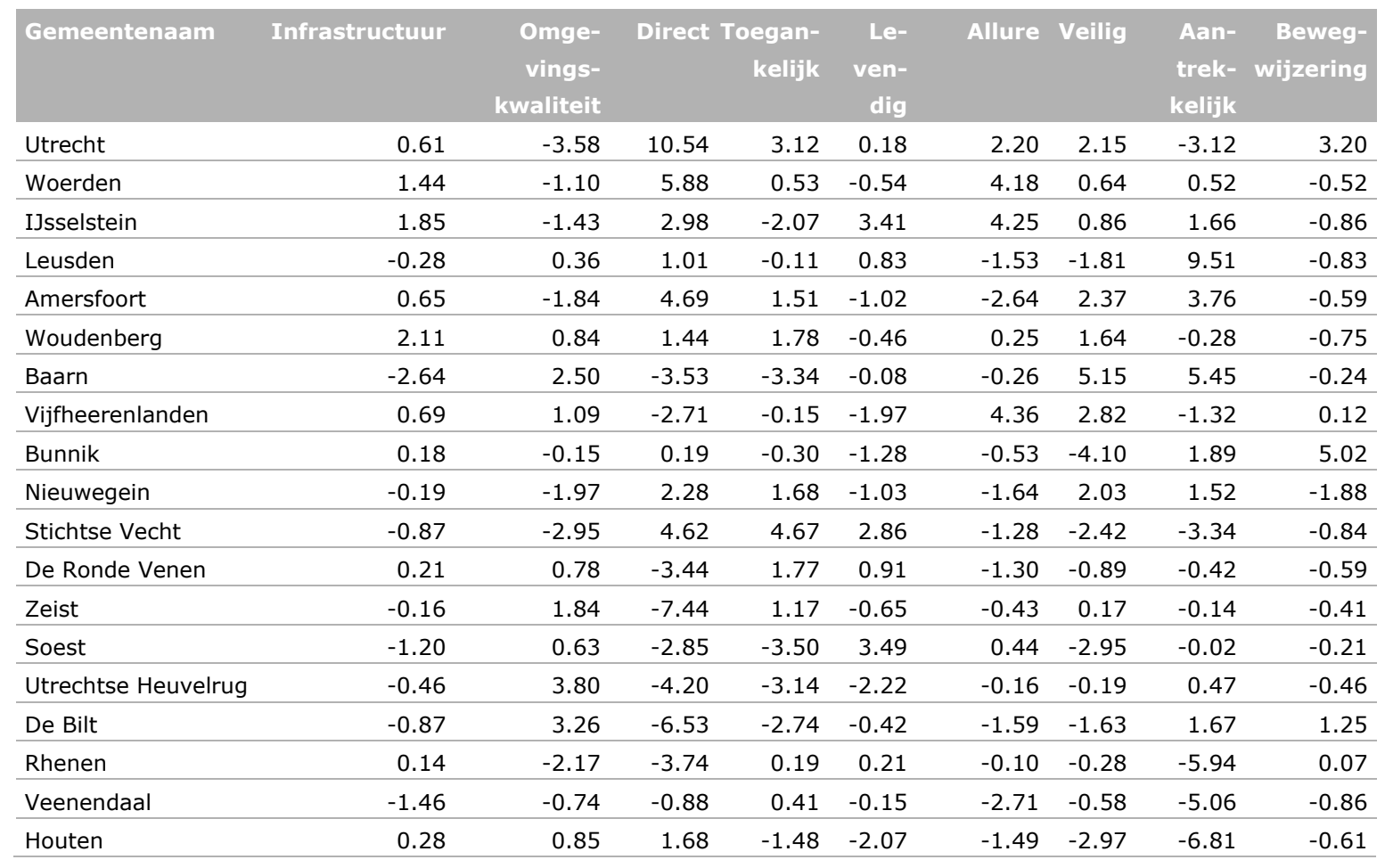

De gemeente Utrecht dankt de hoge loopscore vooral door de zeer hoge score voor de hoofdindicator Directheid van voorzieningen. In deze gemeente hebben buurten relatief veel voorzieningen nabij de Ov-knooppunten. Gemeente Houten heeft relatief veel buurten waar de hoofdindicator Aantrekkelijkheid minder goed scoort en mede daardoor de laagste loopscore heeft. Uit nadere bestudering blijkt dat er in het databestand veel bomen niet opgenomen zijn die wel aanwezig zijn. Er zijn ook relatief weinig houtwallen, groene bermen en voortuinen. Houten scoort hierdoor ook relatief laag op een groene uitstraling en er is enige kans op windhinder en relatief weinig beschutting. 


\subsection{Loopscore per Ov-knooppunt}

De loopscore van de loopmogelijkheden rond bushaltes in de provincie Utrecht is met een gemiddelde $z$-score van 0,17 hoger dan rond treinstations $(-0,05)$.

Tabel 24 Gemiddelde z-score van alle hoofdindicatoren per Ov-knooppunt.

\begin{tabular}{|c|c|c|c|c|c|c|c|c|c|}
\hline Gemeentenaam & Infrastructuur & $\begin{array}{l}\text { Om- } \\
\text { gevings- } \\
\text { kwaliteit }\end{array}$ & Direct & $\begin{array}{r}\text { Toegan- } \\
\text { kelijk }\end{array}$ & $\begin{array}{l}\text { Le- } \\
\text { ven- } \\
\text { dig }\end{array}$ & Allure & Veilig & $\begin{array}{l}\text { Aan- } \\
\text { trek- } \\
\text { kelijk }\end{array}$ & $\begin{array}{r}\text { Beweg- } \\
\text { wijzering }\end{array}$ \\
\hline Treinstation & -0.01 & 0.00 & 0.03 & -0.02 & -0.02 & -0.01 & 0.00 & -0.08 & 0.07 \\
\hline
\end{tabular}

Bushaltes scoren gemiddeld op bijna elke hoofdindicator hoger dan treinstations, behalve op Directheid van voorzieningen en Bewegwijzering (tabel 24).

Toch is in de provincie Utrecht het hoogst scorende Ov-knooppunt een treinstation, namelijk Utrecht Centraal Station (tabel 25).

Tabel 25 Gemiddelde loopscore per Ov-knooppunt.

\begin{tabular}{|c|c|c|c|}
\hline Ov-knooppunt & Loopscore & Ov-knooppunt & Loopscore \\
\hline Utrecht Centraal & 11.28 & Amersfoort Schothorst & -0.27 \\
\hline Vleuten & 3.67 & Bilthoven & -0.29 \\
\hline Houten & 2.88 & Driebergen - Zeist & -1.07 \\
\hline Bunnik & 2.06 & Den Dolder & -1.08 \\
\hline Utrecht Vaartsche Rijn & 1.87 & Houten Castellum & -1.60 \\
\hline Utrecht Terwijde & 1.73 & Veenendaal West & -1.77 \\
\hline Utrecht Lunetten & 1.66 & Soest Zuid & -2.19 \\
\hline Maarssen & 1.54 & Amersfoort Centraal & -2.26 \\
\hline De Poort & 0.84 & Veenendaal Centrum & -3.21 \\
\hline Groene Zoom & 0.35 & Abcoude & -3.85 \\
\hline Mijdrecht centrum & 0.19 & Rijnsweerd-Noord & -4.07 \\
\hline P+R Science Park & -0.12 & Rhenen & -5.14 \\
\hline Stadscentrum & -0.22 & Utrecht Leidsche Rijn & -5.55 \\
\hline Leerdam & -0.25 & Breukelen & -5.60 \\
\hline
\end{tabular}

Utrecht Centraal Station heeft binnen 300 m 284 loopmogelijkheden (11,8 km). Daarvan heeft $88 \%$ $(10,3 \mathrm{~km})$ een zeer hoge beloopbaarheid en $8 \%(921 \mathrm{~m})$ een hoge beloopbaarheid (figuur 12$)$. Een gemiddelde beloopbaarheid heeft $4 \%(484 \mathrm{~m})$ en de rest een (zeer) lage beloopbaarheid. Binnen dit gebied heeft de stationshal de hoogste loopscore en daarmee van heel de provincie Utrecht. 


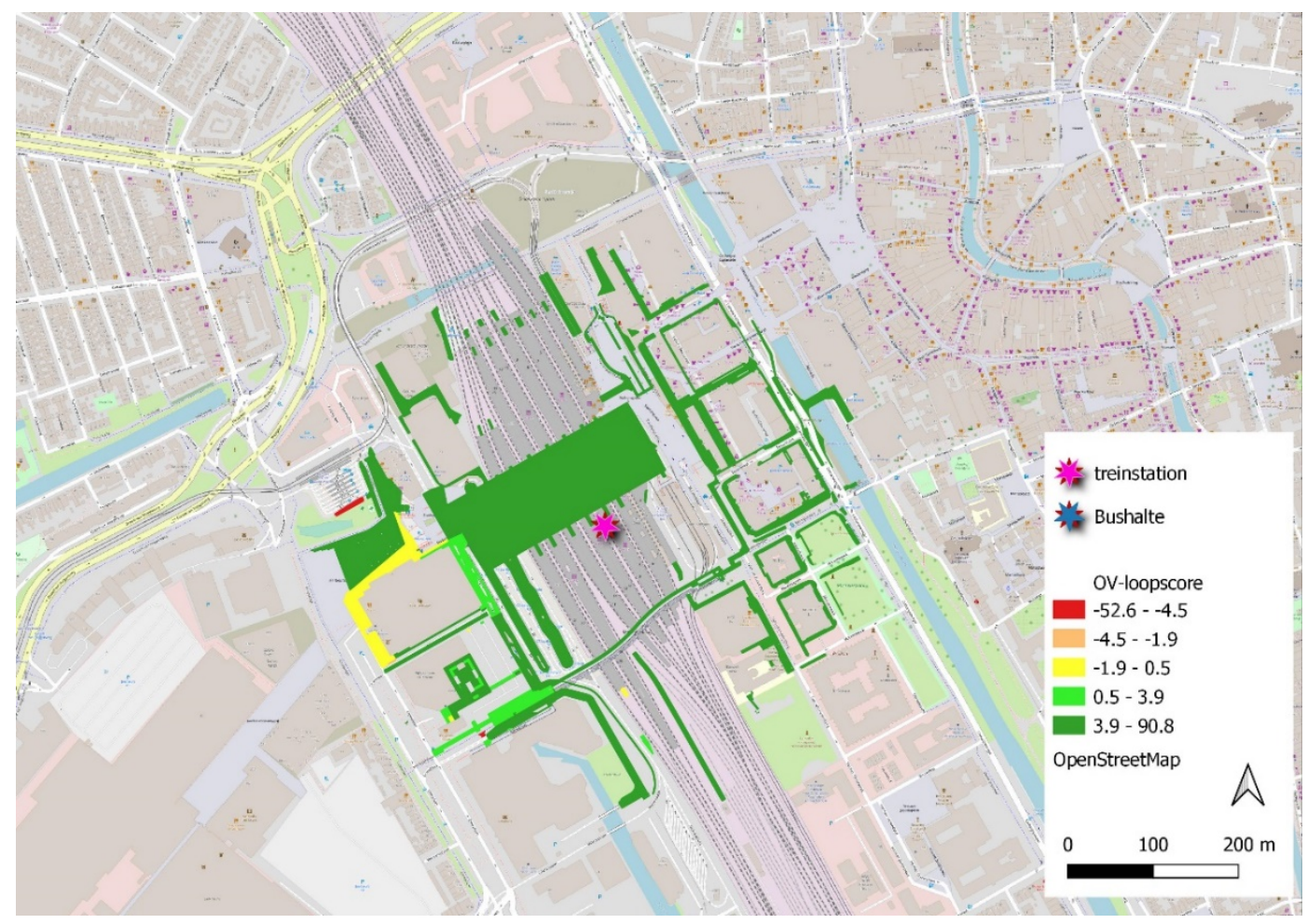

Figuur 12 Loopscore rond Utrecht Centraal Station.

Utrecht Centraal Station scoort vooral op de hoofdindicator Directheid van voorzieningen en Bewegwijzering, maar minder op Aantrekkelijkheid en Omgevingskwaliteit.

Van de Ov-knooppunten heeft $42 \%$ een positieve loopscore. Dat betekent dat de meerderheid (58\%) van de knooppunten een negatieve loopscore heeft.

Treinstation Breukelen heeft met $-5,6$ de gemiddeld laagste loopscore van de provincie. Rond station Breukelen zijn er 82 loopmogelijkheden met in totaal 6,7 km. Het is niet mogelijk om lopend vanuit de woonkern het station te bereiken binnen $300 \mathrm{~m}$. Van de loopmogelijkheden heeft 42\% (2,8 km) een zeer lage beloopbaarheid (figuur 13).

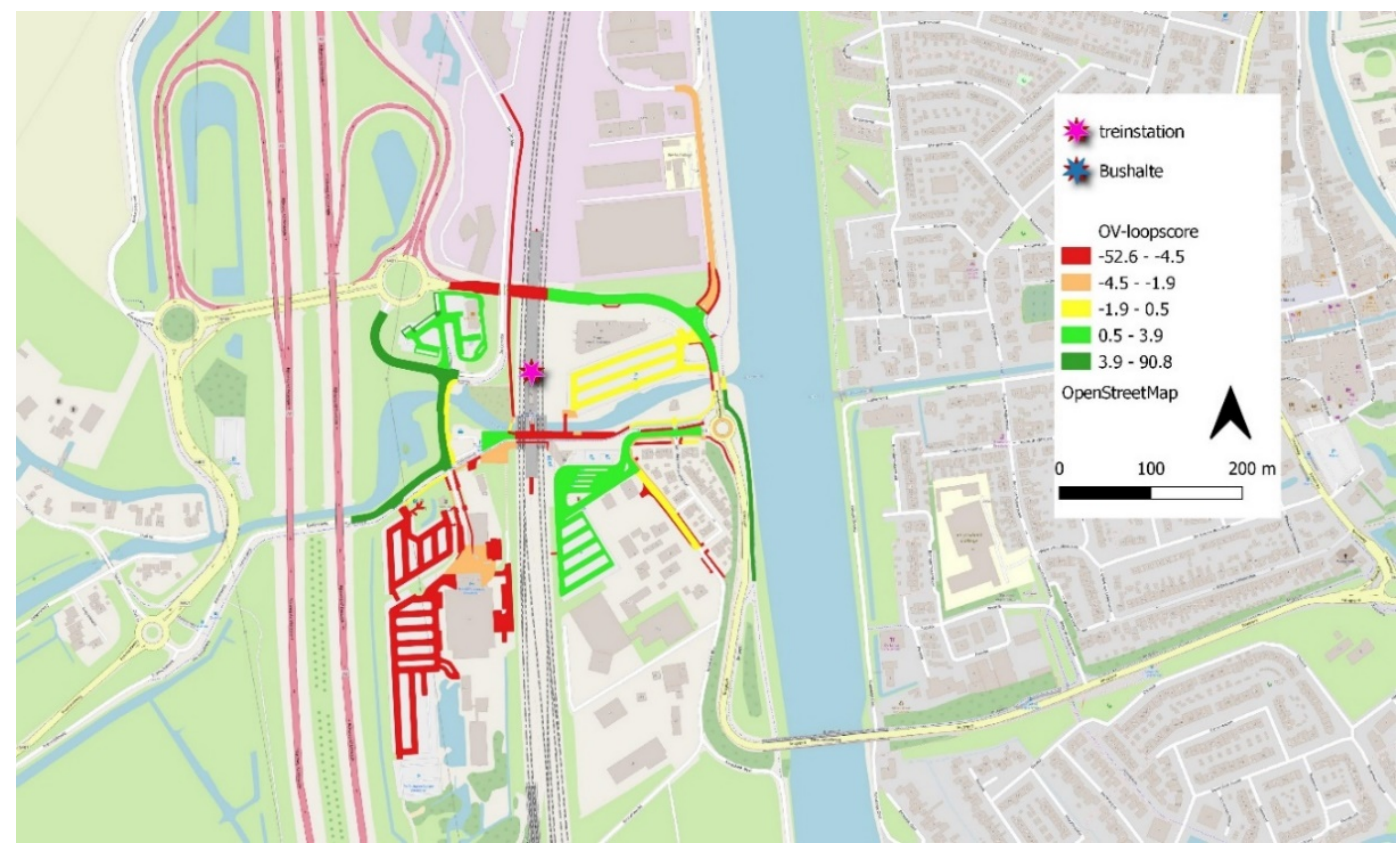

Figuur 13 Loopscore rond Station Breukelen. 
Deze liggen vooral ten zuiden van het station en betreffen een industriegebied. Circa $10 \%$ (685 m) scoort een lage beloopbaarheid en 14\% (938 m) gemiddeld. Van de loopmogelijkheden rond dit station heeft $24 \%(1,6 \mathrm{~km})$ een hoge beloopbaarheid en $10 \%$ (672 m) een zeer hoge. Dit station scoort nog een beetje op de hoofdindicator Aantrekkelijkheid door de aanwezigheid van water en de hoofdindicator Toegankelijkheid. De overige hoofdindicatoren scoren allemaal negatief.

Van alle Ov-knooppunten scoort de Zamenhofdreef in de gemeente Utrecht het hoogst (2.02) bij de bushaltes.

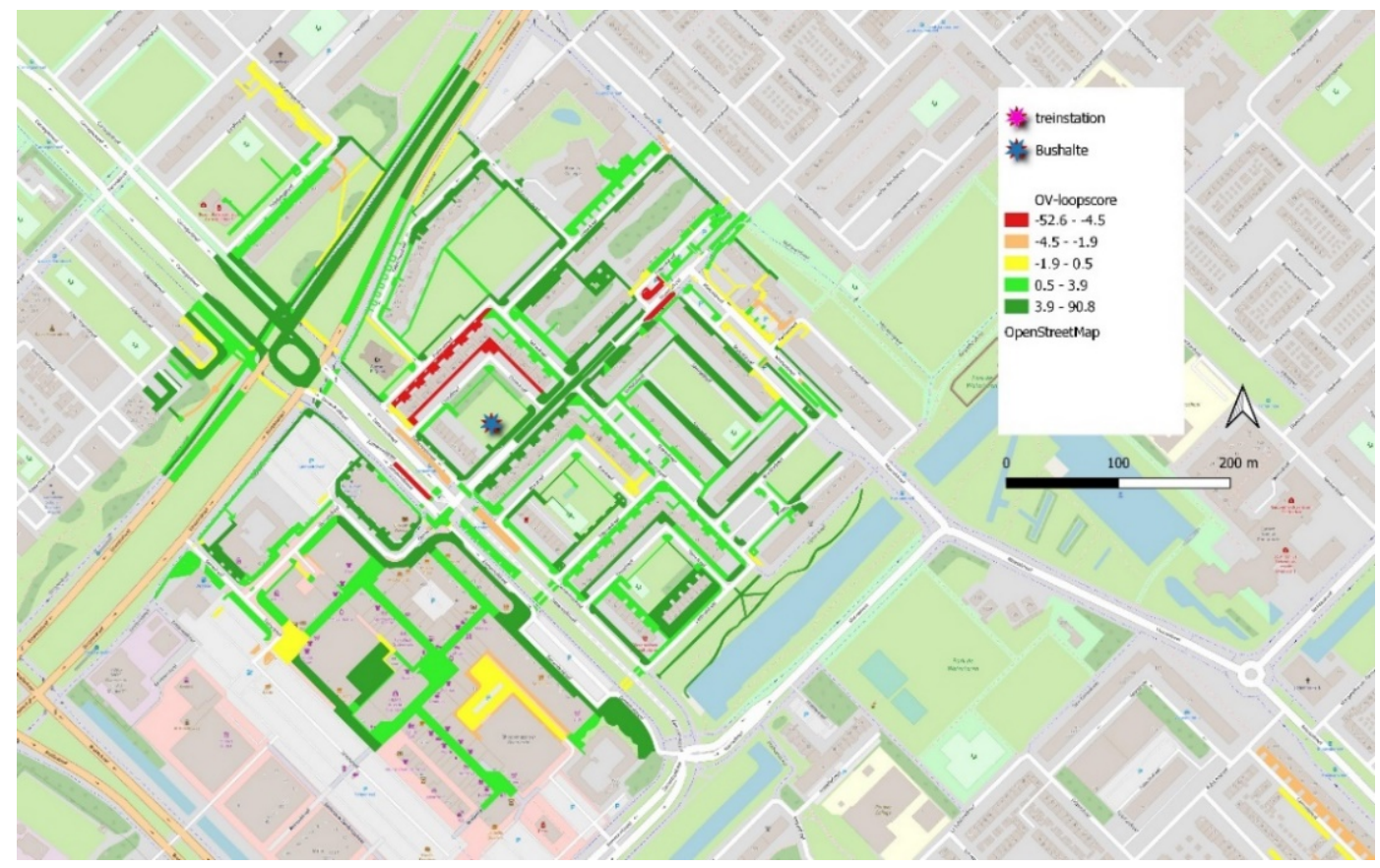

Figuur 14 Loopscore rond bushalte Zamenhofdreef.

Dit komt vooral door de hoeveel voorzieningen in de directe omgeving, de toegankelijkheid, levendigheid en de infrastructuur. De omgevingskwaliteit en de aantrekkelijkheid scoren bij deze bushalte minder. Dit komt vooral door de kans op windhinder als gevolg van de hoge flats. Van de $15,8 \mathrm{~km}$ aan loopmogelijkheden rond deze bushalte heeft $42 \%(6,6 \mathrm{~km})$ een hoge beloopbaarheid en $39 \%(6,2 \mathrm{~km})$ een zeer hoge beloopbaarheid. Circa 4\% (707 m) heeft een lage beloopbaarheid en $3 \%$ (535 $\mathrm{m}$ rond de flats) een zeer lage beloopbaarheid. Circa $11 \%(1,7 \mathrm{~km})$ scoort gemiddeld.

Van alle ov-knooppunten scoort Rijnsweerd-Noord in de gemeente Utrecht het laagst (-4.1) bij de bushaltes. Dit komt vooral door de weinige voorzieningen in de directe omgeving en de omgevingskwaliteit. Van de 6,1 km aan loopmogelijkheden rond deze bushalte heeft $36 \%(2,2 \mathrm{~km})$ een zeer lage beloopbaarheid en $20 \%(1,2 \mathrm{~km})$ een lage beloopbaarheid. Circa $17 \%(1 \mathrm{~km})$ heeft een hoge beloopbaarheid en $5 \%(313 \mathrm{~m})$ een zeer hoge beloopbaarheid. Circa $2 \%(1,3 \mathrm{~km})$ scoort gemiddeld. Vooral ten zuiden van het provinciehuis is de beloopbaarheid laag (figuur 15). 


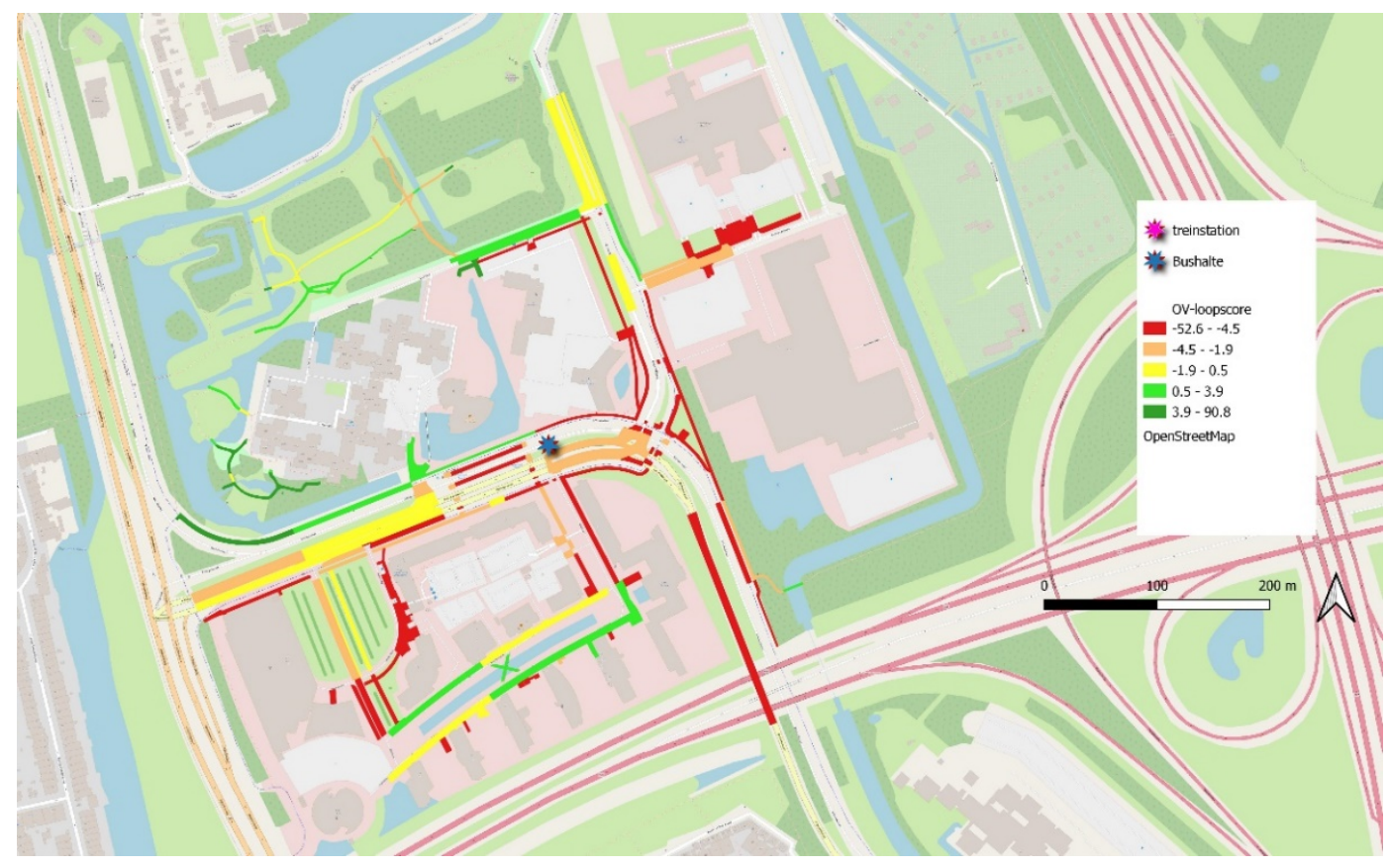

Figuur 15 Loopscore rond bushalte Rijnsweerd-Noord.

\subsection{Handelingsperspectieven}

Gemeenten kunnen de scores zelf inzien en gerichte selectiemogelijkheden maken met behulp van QGIS. QGIS is een open source GIS-programma. In de ontwikkelde shape-file zijn de loopscores van alle loopmogelijkheden zichtbaar op een kaart. Tevens kan geselecteerd worden op de scores van alle hoofdindicatoren en op de onderliggende database. Het is bijvoorbeeld mogelijk om alle voetpaden smaller dan 1,5 $\mathrm{m}$ te selecteren. Het is nog niet mogelijk om veranderingen in QGIS te laten doorrekenen. Daarvoor moet de Excelfile worden gebruikt.

De Excelfile kan gebruikt worden om te achterhalen in hoeverre een beleidsinitiatief effect heeft op de loopscore. Als voorbeeld wordt het initiatief van het college in de gemeente Utrecht genomen. Het Utrechts college wil het Ledig Erf inrichten als plein voor voetgangers en fietsers. ${ }^{8}$ Hiermee moet het gebied ten zuiden van de binnenstad prettiger worden voor bewoners, bezoekers en passanten. Doorgaand autoverkeer langs de singel via het Ledig Erf is in dit voorstel niet meer mogelijk. Het Ledig Erf wordt autoluw. Daarnaast zijn verblijfskwaliteit, groen, veiligheid en fietsen belangrijke aandachtspunten.

Het Ledig Erf bestaat op dit moment in de loopscoretool uit vijf loopmogelijkheden met een totale loopscore van 20.6 waarmee het in de gemeente Utrecht scoort als zeer goed beloopbaar (figuur 16). De vijf loopmogelijkheden bestaan allemaal uit voetpaden en worden dus veranderd in een voetgangersgebied. De volgende veranderingen zijn in de loopscoretool aangebracht. Omdat het geen doorgaand verkeer meer heeft, gaat de geluidbelasting naar beneden, naar 65dB. De modaliteit blijft onveranderd, want er kan straks ook worden gefietst en het wordt weliswaar autoluw, maar auto's houden een rijbaan, maar wel met een verkeersdrempel. De verblijfskwaliteit wordt vertaald naar het plaatsen van 3 bankjes en het wordt dus een plein. Er zijn zes extra bomen ingevoerd om het groener te maken, evenals vijf bloembakken om het gezamenlijk een groenere uitstraling te geven. Door het plaatsen van extra bomen wordt er ook koelte geschapen. De snelheid van het verkeer is naar beneden bijgesteld van 50 naar $30 \mathrm{~km}$ om het veiliger te maken. De aanwezige verkeerseilanden zijn verwijderd en meer verlichting is toegevoegd.

\footnotetext{
8 https://www.utrecht.nl/nieuws/nieuwsbericht-gemeente-utrecht/ledig-erf-wordt-stadsplein-voor-voetgangers-en-fietsers/
} 


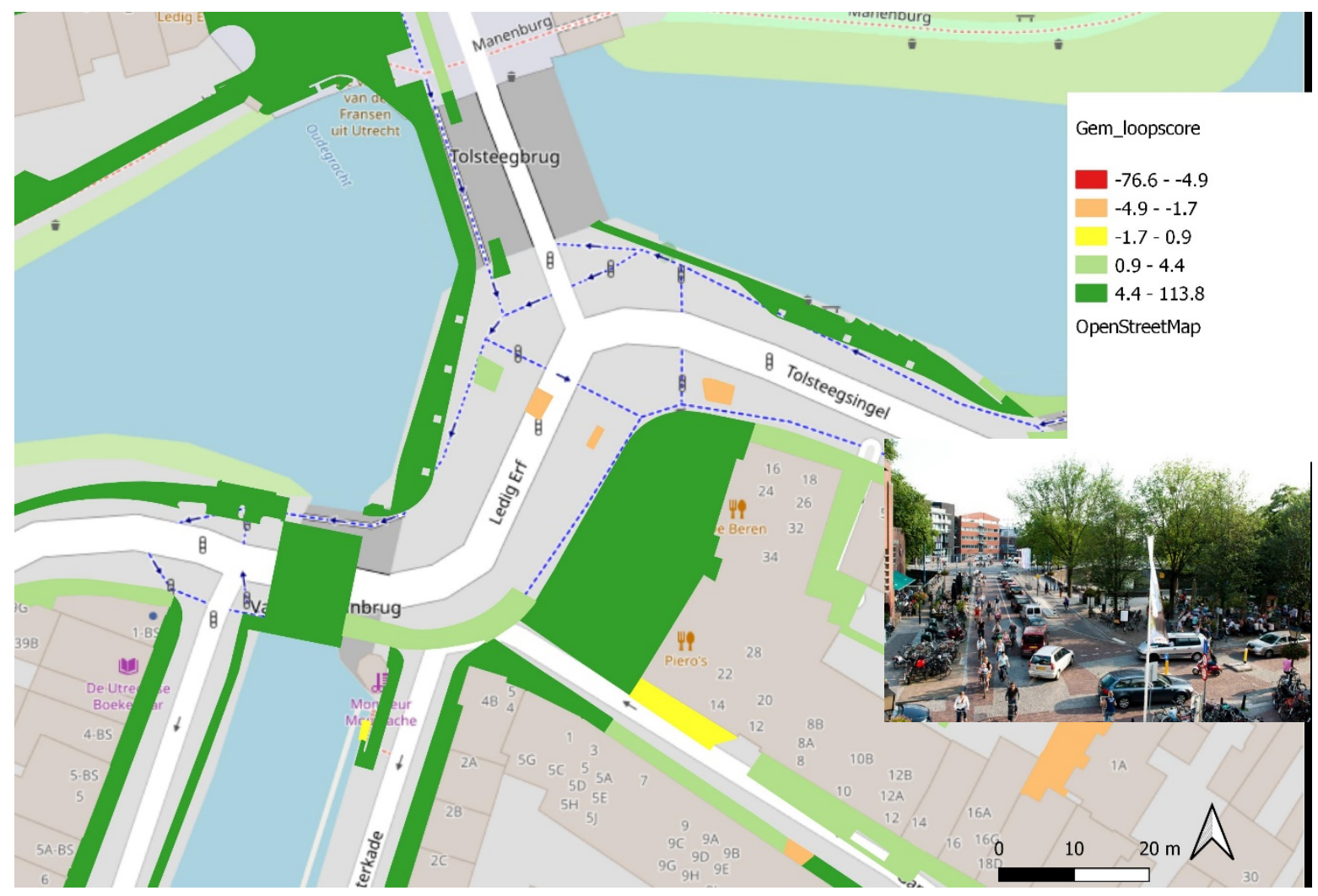

Figuur 16 Loopscore rond Ledig Erf.

Tabel 26 laat zien dat de huidige loopscore van 22.8 door de ingrepen zeer sterk stijgt, naar 408. Dit komt vooral door de hoofdindicator Aantrekkelijkheid.

Tabel 26 Gemiddelde z-score van alle hoofdindicator van de vijf loopmogelijkheden rond Ledig Erf.

\begin{tabular}{lrr} 
Hoofdindicator & Huidige score & Toekomstige score \\
Z_Infrastructuur & -0.13 & 0.35 \\
\hline Z_Omgevingskwaliteit & -23.0 & -14.6 \\
\hline Z_Directheid & 30.8 & 30.8 \\
\hline Z_Toegankelijkheid & -2.3 & -2.3 \\
\hline Z_Levendigheid & 3.7 & 20.0 \\
\hline Z_Allure & 12.8 & 12.8 \\
\hline Z-Veiligheid & 7.9 & 24.9 \\
\hline Z-Aantrekkkelijkheid & -4.0 & 339.5 \\
\hline Z-Bewegwijzering & -3.0 & $\mathbf{- 3 . 0}$ \\
\hline Z_Loopscore & $\mathbf{2 2 . 8}$ & $\mathbf{4 0 8 . 4}$
\end{tabular}

Veel steden willen de omgeving van hun voetpaden vergroenen. Er zijn in de lijst met indicatoren redelijk veel indicatoren te vinden die een groen/blauwe invulling hebben. Maar niet elke indicator is fysiek eenvoudig te verbeteren. Soms kost dit veel ruimte en/of budget. De fysieke ruimte die nodig is om groen te ontwikkelen, is in figuur 17 verdeeld in micro-, meso- en macroniveau. Het groen op microniveau kost de minste fysieke ruimte en vraagt vaak ook minder investeringsbudget. Uit het voorbeeld van Ledig Erf blijkt dat het een groot positief effect kan hebben op de loopscore.

Vergroening kan ook door inwoners zelf gedaan worden door een groene voortuin aan te leggen of via door de overheid stimuleren van Operatie Steenbreek, waarbij een tegel van een voetpad wordt vervangen door een plant of struik.

In figuur 17 is met een (D) aangegeven dat de data reeds in de Excelfile zijn opgenomen waarmee dus berekeningen kunnen worden uitgevoerd om het effect op de loopscore te achterhalen. De 
indicator Onderhoud van groen geldt voor elk schaalniveau. Daarmee kan de Excelfile een bruikbaar instrument zijn bij beleidsvoornemens en diverse handelingsperspectieven.

\begin{tabular}{lll}
\hline Micro niveau & Meso niveau & Macro niveau \\
\hline stoeptegel groen & vijver (D) & recreatiegebied (D) \\
\hline groene gevel & plantsoen (D) & bos (D) \\
bloembak, hangers (D) & park (D) & natuurgebied (D) \\
bomen (D) & sportterrein (D) & agrarisch terrein (D) \\
houtwal (D) & volkstuin (D) & gemengd landgebruik (D) \\
struiken (D) & begraafplaats (D) & \\
lage vegetatie (D) & \\
voortuin & \\
groen schoolplein & \\
geurende plant, struik & & \\
oever, wadi (D) & $<$ conderhoud> & \\
sloot, gracht, rivier (D) & risico wateroverlast (D) \\
waterspeelplaats & verkoelend effect groenblauw (D) & \\
\hline
\end{tabular}

Figuur 17 Groen/blauwe handelingsperspectieven per ruimtelijk schaalniveau.

Medewerkers van de provincie kunnen de Excelfile gebruiken om Ov-knooppunten te selecteren die minder goed scoren op een indicator of indicatoren. Om het gebied rond een Ov-knooppunt voetgangersveiliger te maken, kan bijvoorbeeld geselecteerd worden op voetpaden die nu minder veilig zijn, zoals voetpaden die langs twee of meer modaliteiten liggen en die bovendien smal (tussen de 1 en 1,25 m breed) zijn en minimaal $10 \mathrm{~m}$ lang waarbij geen berm aanwezig is. Dan blijken er 35 loopmogelijkheden te zijn bij 18 Ov-knooppunten die aan deze criteria voldoen (tabel 27).

Tabel 27 Aantal en lengte loopmogelijkheden met beperkte score op aantal indicatoren voor voetgangersveiligheid per Ov-knooppunt.

\begin{tabular}{lrr} 
Ov-knoop punt & Loopmogelijkheden & Lengte (ms) \\
Veenendaal Centrum & 6 & 105 \\
\hline Utrecht Lunetten & 4 & 306 \\
\hline Leerdam & 3 & 137 \\
\hline Driebergen - Zeist & 3 & 314 \\
\hline Houten Castellum & 3 & 181 \\
\hline Breukelen & 2 & 96 \\
\hline Den Dolder & 2 & 243 \\
\hline Bunnik & 2 & 67 \\
\hline Amersfoort Vathorst & 1 & 66 \\
\hline Busstation Lekbrug (west) & 1 & 13 \\
\hline Soest Zuid & 1 & 124 \\
\hline De Poort & 1 & 10 \\
\hline Utrecht Vaartsche Rijn & 1 & 145 \\
\hline Veenendaal West & 1 & 14 \\
\hline Houten & 1 & 33 \\
\hline Zamenhofdreef & 1 & 108 \\
\hline Maarssen & 1 & 100 \\
\hline Rhenen & 1 & 72 \\
\hline Totaal & 35 & 2133 \\
\hline
\end{tabular}

Uit tabel 27 blijken de loopmogelijkheden van deze selectie circa $2 \mathrm{~km}$ te beslaan. Ter illustratie een voetpad in Soest. Ten noorden van treinstation Soest-Zuid ligt een woonwijk van waaruit men alleen het station kan bereiken via een looproute dat aan de meeste van bovenstaande criteria van 'onveilig' voldoet (gele lijn in figuur 18), waarbij er ook nog een verkeerspaal in het voetpad aanwezig is. Dit 

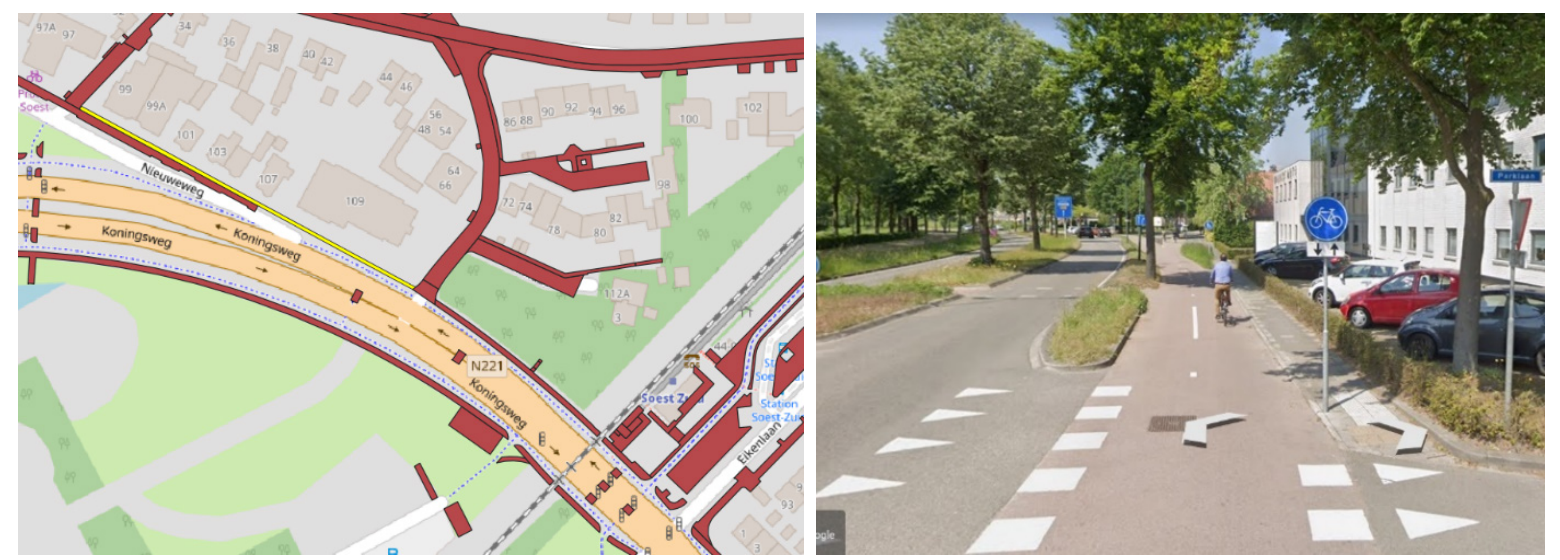

Figuur 18 'Voetgangersonveilig' voetpad bij ov-punt Soest-Zuid.

Veenendaal-Centrum heeft de meeste loopmogelijkheden met deze criteria, maar het zijn allemaal kleine stukjes en vaak oversteekpunten. Het is dus wel nodig om goed in te zoomen en de plaatselijke situatie te onderzoeken.

\subsection{Reflectie}

Het is mogelijk om een loopscore voor loopmogelijkheden te genereren met behulp van open source data. Elke hoofdindicator heeft een score gekregen. Daarmee is het mogelijk om een looproute tussen twee locaties te beoordelen op loopbaarheid. Ook is het mogelijk om de effecten van beleidsvoornemens te berekenen.

De verschillende hoofdindicatoren bestaan uit diverse indicatoren en die zijn niet gelijkmatig verdeeld. De hoofdindicator Aantrekkelijkheid heeft veel indicatoren en daarmee veel invloed op de uiteindelijke loopscore. Dit komt mede omdat de indicatoren nog allemaal even zwaar wegen. Welke indicatoren precies bij een hoofdindicator horen, is echter arbitrair.

Er zijn loopmogelijkheden waar geen data zijn voor een indicator. Die worden niet meegeteld bij de z-score. Maar als bij een loopmogelijkheid geen data bij de bijbehorende indicatoren zijn, scoort die loopmogelijkheid een z-score van 0 . Scoort een loopmogelijkheid wel op een indicator, maar lager dan een andere loopmogelijkheid in die gemeente, dan krijgt de desbetreffende loopmogelijkheid een negatieve z-score. Terwijl er wel een waarde is die eigenlijk hoger moet scoren dan de 0 bij de loopmogelijkheid zonder data. Dit komt vooral bij de hoofdindicatoren Allure en Bewegwijzering voor. $\mathrm{Er}$ is toch gekozen voor een score voor 0 , omdat niet duidelijk is of de indicator goed dan wel minder goed scoort door ontbrekende data. De 0 is dus een soort neutrale score. 


\section{Conclusies en aanbevelingen}

\subsection{Conclusies bij de data}

De belangrijkste conclusie is dat het mogelijk is om de beloopbaarheid van buurten en ovknooppunten te meten met GIS-data. Op basis van (inter)nationaal literatuuronderzoek zijn 160 indicatoren gevonden die iets zeggen over de kwaliteit van een loopmogelijkheid. Van 117 indicatoren (73\%) zijn GIS-data achterhaald. Van 14 indicatoren zijn data alleen op wijk- of gemeenteniveau of voor het buitengebied beschikbaar en deze zijn voor voetpaden niet onderscheidend en daarom vooralsnog niet meegenomen. Een loopscore is derhalve ontwikkeld op basis van 103 indicatoren (64\%). De loopscore geeft daarmee een redelijke indicatie van de

kwaliteit van een voetpad. De aanduiding 'redelijk' is gebaseerd op:

- Niet alle 160 indicatoren zijn opgenomen in de loopscore. Ontbrekende indicatoren zijn vaak sociaal van aard, terwijl de opgenomen indicatoren vaak meer fysiek zijn.

- Omdat nog geen weging is toegepast, is niet duidelijk welke indicatoren (bepaalde) voetgangers erg belangrijk vinden. Het kan dus zijn dat er indicatoren, die voetgangers belangrijk vinden, niet zijn opgenomen wegens het ontbreken van data.

- Op basis van de literatuur lijken belangrijke indicatoren zoals veiligheid en kenmerken van het voetpad zoals breedte en barrières deels wel te zijn opgenomen.

- Van niet alle gebruikte indicatoren zijn volledige data beschikbaar. Een flink aantal indicatoren valt onder het niet-verplichte deel van de BGT. Deze data zijn niet in alle buurten aanwezig en/of volledig.

\section{Indicatoren}

De 160 indicatoren zijn verdeeld naar negen hoofdindicatoren: Begrijpelijke Infrastructuur, Omgevingskwaliteit, Directheid van voorzieningen, Toegankelijkheid, Levendigheid, Allure, Veiligheid, Aantrekkelijkheid en Bewegwijzering. Veruit de meeste hebben betrekking op de hoofdindicator Aantrekkelijkheid, gevolgd door de Toegankelijkheid van het voetpad en Veiligheid. Alle hoofdindicatoren zijn verdeeld in indicatoren waar in principe bij meer dan $\mathbf{5 0 \%}$ data beschikbaar zijn.

Bij de beoordeling van de in gevulde data blijkt dat:

- de data van de hoofdindicator Begrijpelijke Infrastructuur goed zijn;

- het merendeel van de loopmogelijkheden een score kan krijgen voor de hoofdindicator Omgevingskwaliteit en daarmee zijn de data een goede indicatie voor de omgevingskwaliteit van een loopmogelijkheid;

- redelijk veel data voor de hoofdindicator Directheid van voorzieningen afkomstig zijn uit Openstreetmap (OSM). De indruk bestaat dat de Points of Interest uit het OSM een redelijk betrouwbaar beeld geven van de werkelijkheid, ook al is OSM gebaseerd op vrijwilligers die data aanleveren en actualiseren. In de meeste gevallen gaf OSM meer data dan BGT;

- bij de hoofdindicator Toegankelijkheid er veel gemeenten zijn die data van bepaalde indicatoren niet hebben geïnventariseerd en die dus niet in de BGT staan. Dit betreft vooral indicatoren die met barrièrewerking/obstakels te maken hebben. De kwaliteit van de score voor de hoofdindicator Toegankelijkheid is daarom niet geheel duidelijk. Aan de ene kant geeft het een redelijke indicatie van de breedte, lengte en verharding van een loopmogelijkheid, aan de andere kant ontbreken er veel data;

- om een goed beeld te krijgen van de levendigheid, er data ontbreken van belangrijke indicatoren zoals de loopdrukte en aanwezige terrassen. De indicatoren waarvan wel data zijn, komen in beperkte mate voor of zijn niet ingevuld. Dit met uitzondering van de indicatoren Gemengde functies en Bedrijvigheid. Door de aanwezigheid van redelijk betrouwbare data voor deze twee indicatoren geeft de score toch een eerste beeld van de levendigheid;

- de verzamelde data voor de hoofdindicator Allure compleet lijken; 
- de hoofdindicator Veiligheid een beperkte kwaliteit heeft, omdat in iets minder dan de helft van de meegenomen indicatoren geen data gevonden zijn; de score is dus meer een indicatie van veiligheid;

- de hoofdindicator Aantrekkelijkheid veel indicatoren bevat waarbij er voor meer dan de helft data zijn gevonden. De data lijken, op een enkeling na, ook redelijk ingevuld. Dit maakt dat de resultaten een goede indicatie zijn voor deze hoofdindicator;

- van de hoofdindicator Bewegwijzering relatief weinig data zijn, waardoor de kwaliteit beperkt is.

\section{Basisbestand}

Het is essentieel om een basisbestand te hebben dat op kaart aangeeft waar gelopen kan worden. Daarom zijn uit de BGT alle voetpaden, voetgangersgebied en voetpad-op-trap in de betreffende buurten geselecteerd. Wanneer een vergelijking wordt gemaakt met de kaart van Openstreetmap, dan zitten niet alle voetpaden in de BGT, ervan uitgaande dat Openstreetmap klopt.

Als er geen voetpad aanwezig is, kan er toch gelopen worden, bijvoorbeeld op een fietspad. Als er ook geen fietspad is, moet op de rijbaan gelopen worden. In de BGT zitten ook woonerven, inritten en ruiterpaden waarop gelopen kan worden. Vandaar dat we spreken over loopmogelijkheden. Al deze loopmogelijkheden zijn polygonen en zijn opgenomen voor zover ze niet naast een voetpad liggen. Een rijbaan is alleen opgenomen als die niet naast een fietspad en dus voetpad ligt. Daarmee onderscheidt dit systeem zich van ander metingen betreffende walkability.

De polygonen leveren GIS-matig de nodige problemen, want ze zijn niet logisch opgebouwd (een voetpad stopt niet bij een kruising bijvoorbeeld), grillig van vorm en lengte en oppervlakte (er zijn hele kleine polygonen). Bij het selecteren is gebruikgemaakt van buffers waardoor er soms ten onrechte fietspaden en rijbanen zijn verwijderd (met name bij T-kruising) en sommige fietspaden en rijbanen zijn opgenomen omdat ze net buiten de buffer liggen, maar waar wel een voetpad naast ligt.

Uiteindelijk zijn er 63.225 loopmogelijkheden overgebleven waarbij de indruk bestaat dat het merendeel klopt met de werkelijkheid.

De lengte van een loopmogelijkheid is in de analyse belangrijk. De GIS-techniek om de lengte van de polygonen te bepalen, is niet helemaal betrouwbaar bij grillige vormen van polygonen. Ook wordt de lengte soms niet tot aan de rand van een polygoon berekend. Daarom moet de lengte meer gezien worden als een indicatie. Uit de resultaten blijkt dat sommige loopmogelijkheden hoog scoren, maar dat de lengte van de loopmogelijkheid erg beperkt is. Soms niet eens $1 \mathrm{~m}$ lang. Dit komt eigenlijk bij elke hoofdindicator voor. Wanneer er gedeeld wordt door de lengte, geeft dit soms een vertekend beeld en krijgt een score een te zwaar gewicht.

\section{Loopscore}

De beloopbaarheid is uitgedrukt in de loopscore: een kwaliteitsmaat voor de gebruikswaarde (het gemak) en belevingswaarde (aantrekkelijkheid) waarmee over een loopmogelijkheid gelopen kan worden. De ontwikkelde loopscore geeft een eerste indicatie van de kwaliteit van loopmogelijkheden, ondanks de beschreven beperkingen. Het geeft inzicht in welke buurten en Ov-knooppunten de randvoorwaarden voor lopen al dan niet op orde zijn, zodat gericht beleid mogelijk is. Daarmee is een eerste schifting mogelijk om voetpaden te selecteren waar beleidsmatig actie op kan worden gezet. De resultaten geven een handelingsperspectief voor provincie en gemeenten.

\subsection{Conclusies bij de analyse}

In totaal is er circa $3.400 \mathrm{~km}$ aan loopmogelijkheden in de 151 buurten. Daarvan is $68 \%$ een voetpad, $26 \%$ een rijbaan, $5 \%$ een fietspad, en $2 \%$ een woonerf. Gemiddeld ontbreekt in circa $30 \%$ van de buurten en in $25 \%$ van een Ov-knooppunt een voetpad en kan er niet exclusief op een voetpad gelopen worden, maar moet er op een fietspad, rijbaan of woonerf gelopen worden. Dit geldt in verhouding meer voor bushaltes dan voor treinstations. 
De gemiddelde lengte van alle loopmogelijkheden is $49 \mathrm{~m}$. De gemiddelde breedte is $2,2 \mathrm{~m}$ indien alleen de voetpaden worden geselecteerd. Om voetpaden coronaproof te maken (minimaal 2,7 m breed), zou er minimaal $19 \mathrm{~km}$ aan voetpad moeten worden verbreed.

Uit de analyse blijkt dat van de totale lengte aan loopmogelijkheden $\mathbf{5 8} \%$ een positieve loopscore heeft. 11 van de 19 gemeenten hebben een positieve loopscore en 8 een negatieve. De gemeente Utrecht heeft de hoogste loopscore en gemeente Houten de laagste. In de loopscore is de hoofdindicator Directheid van voorzieningen sterk bepalend, omdat er relatief veel data van beschikbaar zijn. De gemeente Utrecht dankt de hoge loopscore vooral door de zeer hoge score voor de hoofdindicator Directheid van voorzieningen. Gemeente Houten heeft relatief veel buurten waar de hoofdindicator Aantrekkelijkheid minder goed scoort. Uit nadere bestudering blijkt dat er in het databestand veel bomen niet zijn opgenomen die wel aanwezig zijn. Er zijn ook relatief weinig houtwallen, groene bermen en voortuinen. Houten scoort hierdoor ook relatief laag op een groene uitstraling, er is enige kans op windhinder en er is relatief weinig beschutting.

Een meerderheid (58\%) van de Ov-knooppunten heeft een negatieve loopscore. Bushaltes scoren beter op de meeste hoofdindicatoren dan treinstations. Treinstations scoren alleen beter op directheid van voorzieningen en bewegwijzering. Van alle Ov-knooppunten scoort de Zamenhofdreef in de gemeente Utrecht het hoogst bij de bushaltes en Rijnsweerd-Noord in dezelfde gemeente het laagst.

In de provincie Utrecht is Utrecht Centraal Station het hoogst scorende Ov-knooppunt en treinstation Breukelen het laagst. 96\% van de loopmogelijkheden rond Utrecht Centraal Station heeft een (zeer) hoge beloopbaarheid met de stationshal als hoogst scorende loopmogelijkheid. Treinstation Breukelen heeft met $24 \%$ de minste hoeveelheid voetpaden. Rond dit treinstation heeft $42 \%$ van de loopmogelijkheden een zeer lage beloopbaarheid.

Hieronder volgen de conclusies met betrekking tot de afzonderlijke hoofdindicatoren. Opmerkelijk is dat elke hoofdindicator een andere hoogst scorende entiteit heeft. Dit geldt ook voor de laagst scorende entiteit. Alleen treinstation Leerdam scoort twee keer het hoogst, namelijk op Allure en Veiligheid.

Tabel 28 Hoogst en laagst scorende locatie per hoofdindicator.

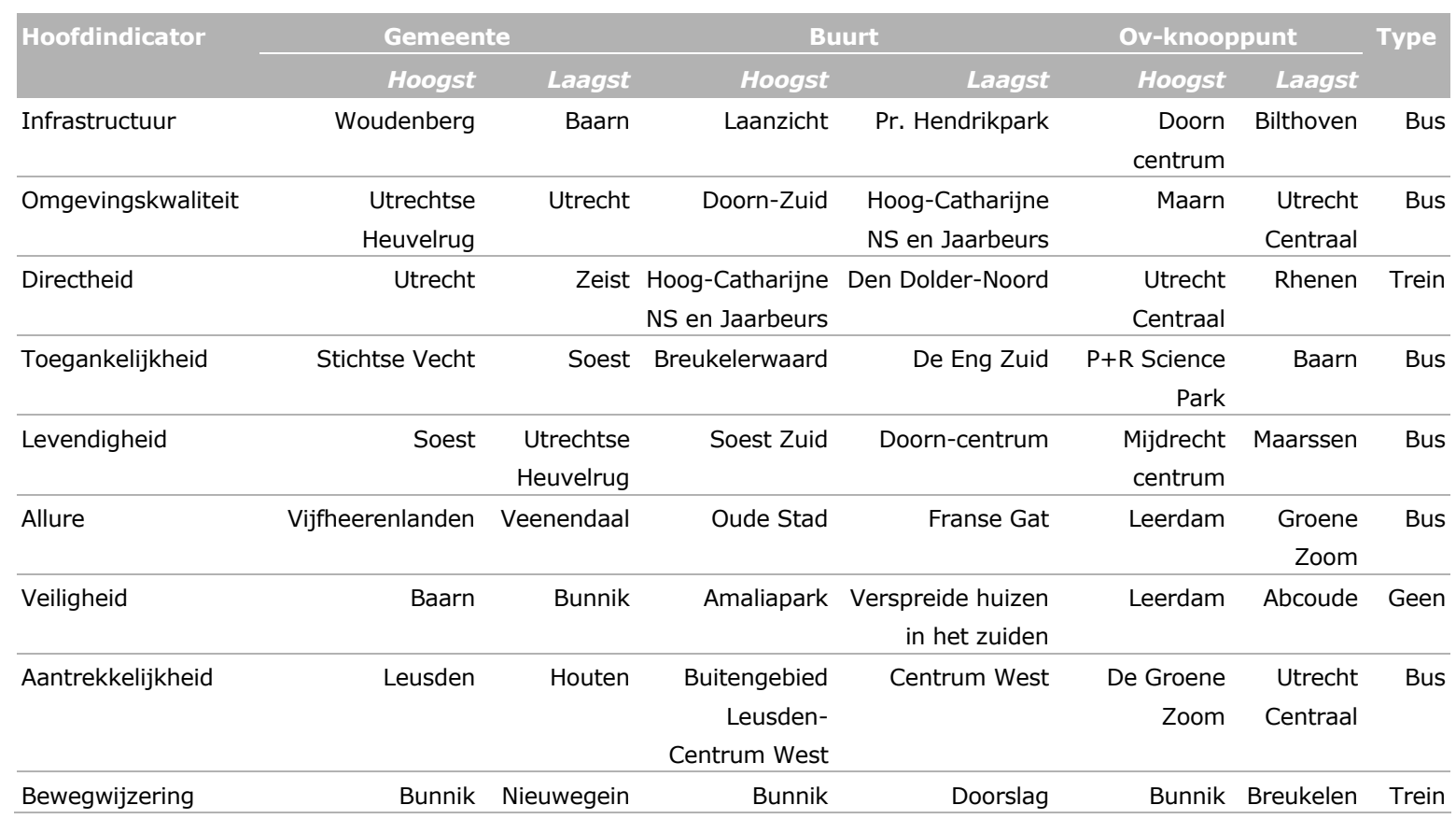


Gebruiksvriendelijk

Het systeem met algoritmes in Excel vraagt veel rekengeheugen en schijfruimte, omdat er veel vergelijkingen gemaakt worden. Dit betekent dat er niet één bestand kan worden gemaakt, want de laptop loopt daarop vast. Door de grootte van het bestand is een landelijke toepassing van de loopscore niet mogelijk. Er is voor gekozen om het bestand op te knippen in afzonderlijke delen waarbij de hoofdindicatoren leidend zijn. Dit levert voor het gemeentebestand vijf aparte bestanden op. Bij de Ov-knooppunten zijn drie aparte bestanden. In een aparte file staat de loopscore van de loopmogelijkheden vermeld, met een interne WENR-verwijzing. Eén gebaseerd op de gemeente als vergelijkingseenheid en een apart file gebaseerd op de Ov-knooppunten van de provincie. Door de interne WENR-verwijzing zijn deze Excelfiles niet zomaar te versturen naar andere instituten. Dit maakt het systeem niet erg gebruiksvriendelijk.

De loopscores van alle loopmogelijkheden zijn zichtbaar gemaakt op een kaart met behulp van QGIS. Tevens kan geselecteerd worden op de scores van alle hoofdindicatoren via QGIS. Met de loopscore is het mogelijk om via QGis een looproute tussen twee locaties te beoordelen op loopbaarheid. Ook is het mogelijk om de effecten van beleidsvoornemens te berekenen, al blijft het echter wel nodig om de plaatselijke situatie in het veld te onderzoeken. Deze effecten kunnen (nog) niet in QGIS worden doorgerekend, maar moet via Excel. Dit maakt het minder gebruiksvriendelijk.

\subsection{Aanbevelingen}

De aanbevelingen richten zich deels op verbeteringen van de rekentool, deels op de resultaten en deels op de gebruiksvriendelijkheid, waardoor gemeenten de tool eerder zullen gaan gebruiken.

\section{Rekentool}

Het verdient aanbeveling om veel zorg te steken in het opbouwen van een basisbestand met loopmogelijkheden. Alle kleine polygonen moeten verwijderd worden. Een discussiepunt is waar de grens ligt van kleine polygonen. In dit project is een oppervlakte van kleiner dan $1 \mathrm{~m}^{2}$ gekozen. Het is wellicht mogelijk om via een iteratief proces van buffering fietspaden en rijbanen die naast een voetpad liggen te verwijderen, zodat een clean basisbestand kan ontstaan.

Onderzoek naar de wijze waarop ook meer data van sociale indicatoren kunnen worden opgenomen Te beginnen met de indicator Loopdrukte. Er kunnen beleidsmatig meer onderbouwde keuzes gemaakt worden om bepaalde loopmogelijkheden als eerste te verbeteren als daar veel gelopen wordt.

Van de indicatoren waarbij data alleen op buurt-, wijk- of gemeenteniveau of voor het buitengebied beschikbaar zijn, zou onderzocht kunnen worden in hoeverre deze indicatoren toch bewerkt kunnen worden op individueel voetpadniveau.

Het is te overwegen om bij de toegankelijkheid sommige indicatoren te verwijderen die slechts potentieel een obstakel zouden kunnen zijn, of weinig voorkomen, zoals putten en bolders. Verbeteringen van de data bij de hoofdindicator Veiligheid is nodig.

De definitie van de indicator Plein moet worden aangepast, want nu zijn veel werkelijk aanwezige pleinen niet in het bestand opgenomen. Ook de definities van oude gebouwen, boulevard en hoogte van panden zijn voor discussie vatbaar.

Het ruimtelijk koppelen van indicatoren is nu gebeurd door buffers te trekken. In sommige gevallen, zoals een T-kruising, levert dit onjuiste uitkomsten. Een nadere GIS-studie is nodig om dit probleem op te lossen. Nadere studie is ook nodig om de lengte van polygonen adequater te kunnen berekenen.

In het systeem scoren loopmogelijkheden zonder data op een indicator een 0 , omdat het niet duidelijke is hoeveel er aanwezig is van die indicator en een 0 geeft dan een neutraal beeld. Maar er zijn ook loopmogelijkheden die wel voor die indicator een hoeveelheid hebben, maar minder dan overige loopmogelijkheden. De z-score is dan negatief en dus lager dan 0 . Dit is niet helemaal terecht en zou aangepast moeten worden. 


\section{Analyse}

Onderzoek naar de onderlinge weging van de indicatoren is van belang. Met name of deze weging per doelgroep verschillend is en/of afhankelijk van de doelstellingen van een gemeente. De uiteindelijke loopscore van loopmogelijkheden in een buurt zou daarna ter validatie kunnen worden getoetst middels een enquête onder voetgangers en/of inwoners in die buurt.

De Excelfiles leveren een schat aan gegevens op waarmee diverse analyses gedaan kunnen worden, zoals een relatie tussen de woningprijzen en de loopscore in een buurt. Of de gezondheid van bewoners in een buurt gerelateerd aan de loopscore en welke (hoofd)indicatoren daarbij het meest van belang zijn.

Provincie Utrecht kan beleidsmedewerkers van gemeenten met het bestand en de indicatoren ondersteunen met het formuleren van de verbeterkansen om buurten en Ov-knooppunten voetgangersvriendelijker te maken. De indicatoren en data kunnen ook gebruikt worden bij een monitoringstool. De lijst met 160 indicatoren krijgt een meerwaarde door het te koppelen aan andere beleidsterreinen, zoals klimaatbeleid, waterbeleid, ruimtelijk beleid en gezondheidsbeleid.

\section{Gebruiksvriendelijk}

Het is raadzaam te onderzoeken of de rekencapaciteit verkleind kan worden via slim programmeren, zodat het systeem gebruiksvriendelijker wordt. Mocht dit niet mogelijk zijn, dan is er wellicht de mogelijkheid om de Exceltabellen in de cloud van de provincie te zetten.

Er zou een gebruiksvriendelijk dashboard gemaakt kunnen worden, bijvoorbeeld om ontbrekende data in te voeren of om effecten van berekeningen te laten zien. Dit zou een webbased versie kunnen zijn. Bijvoorbeeld met behulp van digital twin software of via een app. Dan zouden ook inwoners ingeschakeld kunnen worden om ontbrekende data van hun straat of buurt in te vullen. 


\section{Literatuur}

Ubeda Briones, Julia, 2017. Visualizing and analysing walkability in Amsterdam. Research Internship at Verkeer en Openbare Ruimte (V\&OR), Gemeente Amsterdam. Geographical Information Management and Applications (GIMA) Utrecht University, WUR, TUD and ITC.

Cervero R. and Kockelman K. (1997). Travel demand and the 3ds: density, diversity, and design". Transportation Research Part D 2(3), 199-219.

Giles-Corti, B., Broomhall, M. H., Knuiman, M., Collins, C., Douglas, K., Ng, K. and Donovan, R. J. (2005). Increasing walking: how important is distance to, attractiveness, and size of public open space?. American Journal of Preventive Medicine, 28(2), 169-176.

Sundquist, K., Eriksson, U., Mezuk, B. and Ohlsson, H. (2015). Neighborhood walkability, deprivation and incidence of type 2 diabetes: A population-based study on 512,061 Swedish adults. Health and Place $31,24-30$

James, P., Banay, R.F., Hart, J.E., Laden, F. (2015). Current Epidemiology Reports 2 (2), 131-142. doi: $10.1007 /$ s40471-0150043-7

Borst, H., Miedema, H., Vries, S., Graham, J. and Dongen, J. van. (2008) Relationships between street characteristics and perceived attractiveness for walking reported by elderly people. Journal of Environmental Psychology 28(4), 353-361.

Geh, J. (2010). Cities for People.288pp

Gehl, J. and Svarre, B. (2013) How to study public life. Island Press. 20pp https://islandpress.org/book/how-to-study-public-life

Gehl Architects (2004). Towards a Fine city for people: Public Spaces and Public Life - London 2004. Central London Partnership and Transport for London. https://issuu.com/gehlarchitects/docs/issuu_270_london_pspl_2004

Gehl Architects (2014). Public Spaces, Public Life 2007 Sydney https://issuu.com/gehlarchitects/docs/issuu_516_sydney_pspl2007

Troped, P. J., Wilson, J. S., Matthews, C. E., Cromley, E. K., and Melly, S. J. (2010). The built environment and location-based physical activity. American Journal of Preventive Medicine 38(4), 429-438.

Gauvin, L., Richard, L., Craig, C. L., Spivock, M., Riva, M., Forster, M. and Potvin, L. (2005). From walkability to active living potential: an "ecometric" validation study. American Journal of Preventive Medicine 28(2), 126-133.

Clifton, K., Livi Smith, A.D. and Rodriguez, D. (2007). The development and testing of an audit for the pedestrian environment. Landscape and Urban Planning 80, 95-110.

Hollenstein, D. and Bleisch, S. (2016). Walkability for different urban granularities. The International Archives of the Photogrammetry, Remote Sensing and Spatial Information Sciences, Volume XLIB2, XXIII ISPRS Congress, July 2016, Prague. Doi:10.5194/isprsarchivesXLI-B2-703-2016

Rattan, A., Campese, A. and Eden, Ch. (2012). Modeling walkability. Automating analysis so it is easily repeated. Winter, Esri.com http://www.esri.com/news/arcuser/0112/files/walkability.pdf 
Bakker, M., Boneschansker, N., Niekerk, F., Woltjer, J. (2012). Walkability Kansenkaart.

Rijksuniversiteit Groningen

Transport for London. (2010). Pedestrian Comfort Level Guidance. London. 41 pp http://content.tfl.gov.uk/pedestrian-comfortguidance-technical-guide.pdf

Methorst, R., Monterde i Bort H., Risser R., Sauter D., Tight M. \& Walker J. (Eds.) (2010) Pedestrians' Quality Needs. Final Report of the COST project 358, Cheltenham, UK: Walk21, URL: http://www.walkeurope.org/final_report/default.asp

Ramirez, et al. (2006) 'Indicators of Activity-Friendly Communities: An Evidence-Based Consensus Process' in American Journal of Preventive Medicine, 31:6, Pages 515-524, Dec 2006, URL: http://www.ajpmonline.org/article/PIIS0749379706003059/fulltext

Transport for London (2008) Attitudes to walking 2008 - Research Report, London, UK, URL: http://www.tfl.gov.uk/assets/downloads/businessandpartners/attitudes-to-walking-2008research-report.pdf

Speck, J. (2014). Alburquerque, New Mexico: Downtown walkability analysis. AICP, CNU-A, Leed-AP, asla, Speck and Asssociates LLC. 100pp https://www.cabq.gov/council/documents/councilordistrict2-documents/ABQReport.pdf

Ewing, R., \& Handy, S. (2009). Measuring the Unmeasurable: Urban Design Qualities Related to Walkability. Journal of Urban Design, 14(1), 65-84. https://doi.org/10.1080/13574800802451155

Saunders, L., 2017. Healthy streets. Urban Design Group Journal, 142, pp.35-36.

World Health Organization, 2007. Checklist of essential features of age-friendly cities.http://www.who.int/ageing/publications/Age_friendly_cities_checklist.pdf.

Pedestrian and Bicycle Information Centre. National Association of City Transportation Officials (NACTO) Urban Street Design Guide. https://nacto.org/publication/urban-street-design-guide/street-design-elements/sidewalks/

Veilig Verkeer Nederland, 2007. Beoordeling met behulp van KiSS (Kinder Straat Scan), versie 3.0. http://www.woonerfgoed.nl/bnl/Kindvriendelijk_files/KiSS03VVN-DUTCH-Version.pdf

Amsterdam Zuidoost, 2012. Checklist toegankelijkheid openbare ruimte. https://www.publicspaceinfo.nl/media/uploads/files/AMSTERDAM_2012_0019.pdf

Transport for London, 2011. Pedestrian Environment Review System (PERS). TRL. https://trlsoftware.com/products/road-safety/street-auditing/streetaudit-pers/

Zuniga-Teran, A.A., Orr, B.J., Gimblett, R.H., Chalfoun, N.V., Going, S.B., Guertin, D.P. and Marsh, S.E., 2016. Designing healthy communities: A walkability analysis of LEED-ND. Frontiers of Architectural Research, 5(4), pp.433-452.

Turner Philip, Jim Walker, Marcus Klehr, 2020. PUBLISHED ON BEHALF OF THE URBAN AGENDA FOR THE EU BY International Association of Public Transport (UITP), Walk21 Foundation, Verkehrsbetriebe Karlsruhe (VBK)

Irvine Minnesota Inventory (IMI), 2011. State of Place. https://www.tigard-or.gov/Projects/TigardTriangle/StateofPlace_final_report.pdf http://www.stateofplace.co/our-customers/swissfederalrailways

Giles-Corti, B., Knuiman, M., Timperio, A., Van Niel, K., Pikora, T. J., Bull, F. C., Shilton, T., \& Bulsara, M. (2008). Evaluation of the implementation of a state government community design 
policy aimed at increasing local walking: Design issues and baseline results from RESIDE, Perth Western Australia. Preventive Medicine, 46, 46-54.

Leidelmeijer, K., Marlet, G., Ponds, R., Schulenberg, R. and van Woerkens, C., 2014. Leefbaaro 2.0: instrumentontwikkeling. Rigo Research en Advies \& Atlas voor de gemeenten.

Pharos, 2018. De Leefplekmeter, Wat vind je van je leefplek?

Cammelbeeck, C., Engbers, L., Kunen, M. and L'abée, D., 2013. Ontwerp principes voor een beweeg vriendelijke omgeving.

Institute for Transportation and Development Policy Pedestrians First, Tools For a Walkable City. 1st ed. New York: ITDP, 2018.

Burger, J.E.J.M. en Bruin, T.J., 2004. Ruimte voor de wandelaar: de ommetjesmaker en zijn habitat. Uitgeverij Op Lemen Voeten/Stichting Op Lemen Voeten.

Liao, B., van den Berg, P.E., van Wesemael, P.J. and Arentze, T.A., 2020. Empirical analysis of walkability using data from the Netherlands. Transportation Research Part D: Transport and Environment, 85, p.102390.

Luijkx, M. and Helbich, M., 2019. Neighborhood Walkability Is Not Associated with Adults' Sedentary Behavior in the Residential Setting: Evidence from Breda, The Netherlands. International journal of environmental research and public health, 16(18), p.3487.

Duncan, D.T., Aldstadt, J., Whalen, J., Melly, S.J., Gortmaker, S.L., 2011.Validation of WalkScore $®$ for estimating neighborhood walkability: an analysis of four US metropolitan areas.Int.J.Environ.Res.PublicHealth8.https://doi.org/10.3390/ijerph8114160.

Frank, L.D., Engelke, P., 2005. Multiple impacts of the built environment on public health: walkable places and the exposure to air pollution.Int.Reg.Sci.Rev.28, 193-216.

Weiss, R.L., Maantay, J.A., Fahs, M., 2010. Promoting active urban aging: a measurement approach to neighborhood walkability for older adults. CitiesEnviron.3,12.

Glazier, R.H., Weyman, J.T., Creatore, M.I., Gozdyra, P., Moineddin, R., Matheson, F.I. and Booth, G.L., 2012. Development and validation of an urban walkability index for Toronto, Canada. Toronto Community Health Profiles Partnership, pp.1-21.

Habibian, M. and Hosseinzadeh, A., 2018. Walkability index across trip purposes. Sustainable cities and society, 42, pp.216-225.

Health by Design, 2010. How Walkable is Your Neighborhood?

Molster, A. \& S. Schuit, 2020. Loop! Tien ontwerpprincipes voor een loopvriendelijke omgeving.

Wagtendonk, A.J. \& J. Lakerveld, 2019. Walkability score Netherlands version 1.0; Dataset and technical documentation of data and methods. Department of Epidemiology and Biostatistics, Amsterdam Public Health Research Institute, Amsterdam UMC

CROW-KpVV, 2020. Uitwerking kwaliteitseis aantrekkelijkheid van looproutes

Sweco, 2021. Invloedsgebied van OV-knooppunten (in voorbereiding)

Van den Berg, A. E., Bloemmen, M. H. I., de Boer, T. A., \& Lankhorst, J. R. K. (2002). De beleving van watertypen: literatuuroverzicht en validatie van de indicator 'water' uit het BelevingsGis. 


\section{Bijlage 1 Overzicht indicatoren}

\begin{tabular}{|c|c|c|c|c|c|}
\hline Hoofdindicator & Subindicator & $\begin{array}{l}\text { Straat } \\
\text { data }\end{array}$ & Ander Geo data & $\begin{array}{l}\text { Geen } \\
\text { data }\end{array}$ & Totaal \\
\hline \multirow[t]{12}{*}{ Infrastructuur } & Voetgangerszone/pleintjes & 1 & & & \\
\hline & Voetpad in park & 1 & & & \\
\hline & Voetpad & 1 & & & \\
\hline & Inrit & 1 & & & \\
\hline & Voetpad op trap & 1 & & & \\
\hline & Fietspad & 1 & & & \\
\hline & Woonerf & 1 & & & \\
\hline & Ruiterpad & 1 & & & \\
\hline & Geen loopmogelijkheid (straat) & 1 & & & \\
\hline & Modaliteitsscheiding & 1 & & & \\
\hline & Dichtheid aan kruispunten & & 1 & & \\
\hline & Totaal & 10 & 1 & 0 & 11 \\
\hline \multirow[t]{9}{*}{ Omgevingskwaliteit } & Geluidshinder & 1 & & & \\
\hline & Luchtkwaliteitsindex & 1 & & & \\
\hline & Risico op wateroverlast & 1 & & & \\
\hline & Hitte gevoelstemperatuur & 1 & & & \\
\hline & Verkoelend effect van groen en blauw & 1 & & & \\
\hline & Geluidshinder bromfietsen en scooter & & 1 & & \\
\hline & Geurhinder wegverkeer & & 1 & & \\
\hline & Geurhinder bedrijven & & 1 & & \\
\hline & Totaal & 5 & 3 & 0 & 8 \\
\hline \multirow[t]{10}{*}{ Directheid } & Essentiële school vz 1000m & 1 & & & \\
\hline & Essentiële zorg vz 1000m & 1 & & & \\
\hline & Essentiële food voorziening $500 \mathrm{~m}$ & 1 & & & \\
\hline & Bereikbaarheid speeltuinen $500 \mathrm{~m}$ & 1 & & & \\
\hline & Leisure bestemming op $500 \mathrm{~m}$ & 1 & & & \\
\hline & Bereikbaarheid publiek gebouw $500 \mathrm{~m}$ & 1 & & & \\
\hline & Fijnmazigheid ov $800 \mathrm{~m}$ & 1 & & & \\
\hline & Verbinding voetpaden/netwerk & & 1 & & \\
\hline & Doodlopende straten, steegjes & & & 1 & \\
\hline & Totaal & 7 & 1 & 1 & 9 \\
\hline \multirow[t]{22}{*}{ Toegankelijkheid } & Lengte wegdeel connectiviteit & 1 & & & \\
\hline & Breedte wegdeel & 1 & & & \\
\hline & Verharding wegdeel & 1 & & & \\
\hline & Molgoten & 1 & & & \\
\hline & Putdeksels, roosters & 1 & & & \\
\hline & Abri & 1 & & & \\
\hline & Bolder & 1 & & & \\
\hline & Brievenbus & 1 & & & \\
\hline & Reclamebord & 1 & & & \\
\hline & Fietsenrek & 1 & & & \\
\hline & Telefooncel & 1 & & & \\
\hline & Boomspiegel & 1 & & & \\
\hline & Parkeermeter & 1 & & & \\
\hline & $\begin{array}{l}\text { Container, glasbak, recycling, } \\
\text { Prullenbak }\end{array}$ & 1 & & & \\
\hline & Verkeersbord en palen & 1 & & & \\
\hline & Kast & 1 & & & \\
\hline & Geleidelijnen, trapleuning & 1 & & & \\
\hline & Openbare toiletten & 1 & & & \\
\hline & Loopbruggen & & 1 & & \\
\hline & Tunnels & & 1 & & \\
\hline & Pontjes & & 1 & & \\
\hline & Spoorwegovergang & & 1 & & \\
\hline
\end{tabular}




\begin{tabular}{|c|c|c|c|c|c|}
\hline Hoofdindicator & Subindicator & $\begin{array}{l}\text { Straat } \\
\text { data }\end{array}$ & Ander Geo data & $\begin{array}{l}\text { Geen } \\
\text { data }\end{array}$ & Totaal \\
\hline & Hoogteverschil & & 1 & & \\
\hline & Terras als barrière & & & 1 & \\
\hline & Hoogte onderdoorgang & & & 1 & \\
\hline & Hoogte stoeprand & & & 1 & \\
\hline & Gladheid & & & 1 & \\
\hline & Onderhoud wegdeel & & & 1 & \\
\hline & Auto op voetpad & & & 1 & \\
\hline & Wandelcultuur & & & 1 & \\
\hline & Bewustzijn & & & 1 & \\
\hline & Inclusiviteit & & & 1 & \\
\hline & Totaal & 18 & 5 & 9 & 32 \\
\hline \multirow[t]{13}{*}{ Levendigheid } & Leegstaande en vervallen Gebouwen & 1 & & & \\
\hline & Bankjes & 1 & & & \\
\hline & Pleintjes & 1 & & & \\
\hline & Speeltuin/voorziening & 1 & & & \\
\hline & Diversiteit, Menging wonen en werken & 1 & & & \\
\hline & Overkapping/luifel & 1 & & & \\
\hline & Bedrijvigheid van plint (voordeuren) & 1 & & & \\
\hline & Sociale activiteiten & & & 1 & \\
\hline & Straatmuzikanten & & & 1 & \\
\hline & loopdrukte & & & 1 & \\
\hline & Terrassen & & & 1 & \\
\hline & Openluchtpodium & & & 1 & \\
\hline & Totaal & 7 & 0 & 5 & 12 \\
\hline \multirow[t]{6}{*}{ Allure } & Oude gebouwen & 1 & & & \\
\hline & Theater, musea, kastelen $10 \mathrm{~m}$ & 1 & & & \\
\hline & Rijksmonumenten & 1 & & & \\
\hline & Boulevard, wandelpromenade & 1 & & & \\
\hline & Hoogte gebouwen & 1 & & & \\
\hline & Totaal & 5 & 0 & 0 & 5 \\
\hline \multirow[t]{24}{*}{ Veiligheid } & Parkeerplaats auto's & 1 & & & \\
\hline & Maximum snelheid & 1 & & & \\
\hline & Verkeerseilanden & 1 & & & \\
\hline & Straatverlichting & 1 & & & \\
\hline & Berm, al dan niet groen & 1 & & & \\
\hline & Cameratoezicht & 1 & & & \\
\hline & Verkeersremmend/drempel & 1 & & & \\
\hline & Verkeer afsluitende straat & 1 & & & \\
\hline & Eén- of meerrichtingsverkeer & 1 & & & \\
\hline & Verkeerslichten & 1 & & & \\
\hline & Drukknoppaal & 1 & & & \\
\hline & Zebra & 1 & & & \\
\hline & Risicogebied & & 1 & & \\
\hline & Verkeersdrukte & & & 1 & \\
\hline & Verkeersslachtoffers & & & 1 & \\
\hline & Fietsdrukte & & & 1 & \\
\hline & Shared spaces & & & 1 & \\
\hline & Boa's politiesurveillance & & & 1 & \\
\hline & Straatcoaches & & & 1 & \\
\hline & Buurtpreventie-app & & & 1 & \\
\hline & Misdrijf en inbraak op straat & & & 1 & \\
\hline & Image & & & 1 & \\
\hline & Duur voetgangerslicht & & & 1 & \\
\hline & Totaal & 12 & 1 & 10 & 23 \\
\hline \multirow[t]{6}{*}{ Aantrekkelijkheid } & Beelden & 1 & & & \\
\hline & Fonteinen & 1 & & & \\
\hline & Herdenkingsmonument & 1 & & & \\
\hline & Gevelverdeling & 1 & & & \\
\hline & Bomen & 1 & & & \\
\hline & Houtwal & 1 & & & \\
\hline
\end{tabular}




\begin{tabular}{|c|c|c|c|c|c|}
\hline Hoofdindicator & Subindicator & $\begin{array}{l}\text { Straat } \\
\text { data }\end{array}$ & Ander Geo data & $\begin{array}{l}\text { Geen } \\
\text { data }\end{array}$ & Totaal \\
\hline & $\begin{array}{l}\text { Groene berm/overzichtelijk groen/lage } \\
\text { vegetatie }\end{array}$ & 1 & & & \\
\hline & Beek & 1 & & & \\
\hline & Rivier & 1 & & & \\
\hline & Kanaal & 1 & & & \\
\hline & Sloot & 1 & & & \\
\hline & Gracht & 1 & & & \\
\hline & Greppel/droge sloot & 1 & & & \\
\hline & Vijver & 1 & & & \\
\hline & Oever & 1 & & & \\
\hline & Voortuin & 1 & & & \\
\hline & Struiken/haag & 1 & & & \\
\hline & Begraafplaats & 1 & & & \\
\hline & Park en plantsoen & 1 & & & \\
\hline & Recreatiegebied & 1 & & & \\
\hline & Sportterrein & 1 & & & \\
\hline & Volkstuin & 1 & & & \\
\hline & Natuurgebied & 1 & & & \\
\hline & Bos & 1 & & & \\
\hline & Agrarisch terrein & 1 & & & \\
\hline & Grasland & 1 & & & \\
\hline & Gemengd landgebruik & 1 & & & \\
\hline & Groene uitstraling & 1 & & & \\
\hline & Hondenuitlaatplaatsen & 1 & & & \\
\hline & Hoogspanningsmasten & 1 & & & \\
\hline & Afvalbak & 1 & & & \\
\hline & Bloembak/hangers & 1 & & & \\
\hline & Uitzichtpunt & 1 & & & \\
\hline & Beschutting tegen wind & 1 & & & \\
\hline & Beschutting tegen regen en zon & 1 & & & \\
\hline & Biodiversiteit & & 1 & & \\
\hline & Bebouwingsdichtheid & & 1 & & \\
\hline & Open ruimte/onbebouwd & & & 1 & \\
\hline & Groene schoolpleinen & & & 1 & \\
\hline & Waterspeelplaats & & & 1 & \\
\hline & Aangename geuren & & & 1 & \\
\hline & Groene gevel & & & 1 & \\
\hline & Operatie Steenbreek & & & 1 & \\
\hline & Plezierige weersomstandigheden & & & 1 & \\
\hline & Wadi & & & 1 & \\
\hline & Straatverkoop, stalletjes & & & 1 & \\
\hline & Landmarks & & & 1 & \\
\hline & Hondenpoep & & & 1 & \\
\hline & Zwerfhonden & & & 1 & \\
\hline & Bedelaars, zwervers, Drugsverkopers & & & 1 & \\
\hline & Vandalisme & & & 1 & \\
\hline & Graffiti/muurschilderijen & & & 1 & \\
\hline & Hangjongeren & & & 1 & \\
\hline & Afval op straat & & & 1 & \\
\hline & Onderhoud groen & & & 1 & \\
\hline & Totaal & 35 & 2 & 18 & 55 \\
\hline \multirow[t]{6}{*}{ Bewegwijzering } & Toeristische informatie & 1 & & & \\
\hline & Wegwijzers & 1 & & & \\
\hline & Straatnaambordje & 1 & & & \\
\hline & Overzichtskaart & 1 & & & \\
\hline & Wandelroutes & & 1 & & \\
\hline & Totaal & 4 & 1 & 0 & 5 \\
\hline
\end{tabular}




\section{Bijlage 2 Ov-Knooppunten}

\section{Knooppunt ( $B$ )=bushalte}

1. Abcoude

2. Amersfoort

3. Amersfoort Schothorst

4. Amersfoort Vathorst

5. Baarn

6. Bilthoven

7. Breukelen

8. Bunnik

9. Den Dolder

10. Doorn centrum (B)

11. Driebergen-Zeist

12. Houten

13. Houten Castellum

14. IJsselstein Binnenstad (B)

15. Leerdam

16. Leusden Groene zoom (B)

17. Maarn

18. Maarssen

19. Mijdrecht Centrum (B)
20. Nieuwegein Stadscentrum schouwstede (B)

\section{Rhenen}

22. Soest Zuid

23. Utrecht Centraal

24. Utrecht Leidsche Rijn

25. Utrecht Lunetten

26. Utrecht Overvecht

27. Utrecht Rijnsweerd-Noord (B)

28. Utrecht Science Park/Padualaan (B)

29. Utrecht Terwijde

30. Utrecht Vaartsche Rijn

31. Utrecht Zamenhofdreef (B)

32. Utrecht Zuilen

33. Veenendaal Centrum

34. Veenendaal West

35. Vianen Lekbrug (B)

36. Vleuten

37. Woerden

38. Woudenberg de Poort (B) 


\section{Bijlage 3 Berekening en normen}

De normen zijn gebaseerd op enerzijds literatuur zoals de TOD-studie, het boek Loop! (Molster, 2021) en het rapport Aantrekkelijke looproutes van het CROW en anderzijds op een indeling zoals bij de website https://www.atlasleefomgeving.nl/check-je-plek wordt aangehouden. Het komt echter ook voor dat een eigen indeling is gemaakt.

Aangezien de meeteenheden van de diverse indicatoren verschillend zijn, is het niet mogelijk om ze gewoon op te tellen. Sommige meeteenheden zijn een percentage, andere een index, een $d B(A)$ of een ja-nee-situatie (ofwel 1/0). Bij gewoon optellen krijgen de percentagescores een te groot aandeel in de totaalscore. Om dit te voorkomen, zijn er grofweg drie methoden:

- alle meeteenheden naar 100 opschalen om het vergelijkbaar te maken. De oorspronkelijke score blijft dan behouden.

- Een andere indeling is de meeteenheid in klassen verdelen. Als je de scores omzet in een puntenaantal via klassen, kun je ze wel optellen. Discussiepunt is dan waar je de grens van een klasse legt. Tevens valt een verbetering van de totaalscore niet op als de verbetering binnen een klasse ligt. Dat is niet erg stimulerend voor beleidsmakers.

- Om onvergelijkbare meeteenheden te vergelijken, kan ook de z-score per wegdeel worden gebruikt. Met de z-score is het mogelijk om scores op verschillende indicatoren met elkaar te vergelijken, omdat de meeteenheid van een indicator er op deze manier niet meer toe doet. De z-score geeft aan hoeveel standaarddeviaties een score van het gemiddelde af zit. In formule: $z$-score=(waardegemiddelde)/Standaarddeviatie.

Er moet een keuze gemaakt worden warop het gemiddelde wordt gebaseerd. Dit kan de buurt als eenheid zijn of de gemeente of de hele provincie. Een score boven de 0 voor een indicator betekent dat het wegdeel beter scoort dan gemiddeld. Een score lager dan een 0 betekent dat het wegdeel slechter scoort dan gemiddeld. Een probleem is dat het niet uit de resultaten komt als een hele buurt slecht scoort, want het gaat om de afstand tot het gemiddelde. Daarom wordt ook de waarde van het gemiddelde gerapporteerd.

Er is voor de methode z-score gekozen waarbij de aparte wegdelen met elkaar worden vergeleken. Voor Ov-knooppunten is de hele provincie Utrecht de eenheid waarop het gemiddelde wordt gebaseerd. De wegdelen in de buurten worden per gemeente met elkaar vergeleken en vervolgens per buurt opgeteld. Er zijn dus twee aparte berekeningen gemaakt, leidend tot twee aparte Excelfiles.

\section{B3.1 Wegdeel}

Loopmogelijkheden zijn het uitgangspunt, ofwel een wegdeel waarop in principe gelopen kan worden, tenzij het wettelijk verboden is. In tabel B3.1 staan de wegdelen uit de Basisregistratie Grootschalige Topografie (BGT). Fietsstroken op een rijbaan zijn dus niet meegenomen.

De data zijn voor al deze wegdelen verzameld in de 151 buurten. In totaal zijn in deze buurten in eerste instantie ongeveer 82.000 wegdelen geselecteerd. In tabel B3.1 staat de verdeling tussen de diverse loopmogelijkheden.

Vaak is er een rijbaan (straat) met aan beide kanten een voetpad (stoep). Het is dan niet noodzakelijk om in dergelijke gevallen ook de loopscore van de rijbaan te berekenen, aangezien er op de voetpaden kan worden gelopen.

In principe is het voetpad dus de kleinste eenheid. Een voetpad is inclusief een voetgangersgebied, voetpad-op-trap en inrit. Maar als er geen voetpad is, dan kan er mogelijk wel over een fietspad gelopen worden. Dus we selecteren alle fietspaden als er geen voetpad naast ligt. Dit is gedaan door een buffer van $0,1 \mathrm{~m}$ te leggen rond een erfbegrenzing en alle fietspaden in deze buffer te selecteren. Hetzelfde is 
gedaan bij rijbanen en woonerf als er geen voetpad of fietspad naast ligt. Daarnaast worden ook de fietspaden, rijbanen en woonerven meegenomen die niet grenzen aan een erfbegrenzing of voetpad. Dit is gedaan door een buffer van $5 \mathrm{~m}$ te maken rond voetpaden en de fietspaden, rijbanen, woonerven en ruiterpaden te selecteren die niet in de buffer liggen, omdat we ervan uitgaan dat bij een fietspad of rijbaan binnen de buffer er wel op het voetpad gelopen zal worden.

Tabel B3.1 Verdeling type loopmogelijkheden per selectie.

\begin{tabular}{lrrrr} 
& \multicolumn{2}{c}{ Alle Wegdelen } & Wegdelen bij berekening \\
\cline { 2 - 5 } Type loopmogelijkheid & Aantal & Percentage & Aantal \\
Voetpad & 39.315 & 48 & 38.669 & 61 \\
\hline Voetpad op trap & 1.515 & 2 & 1.348 & 580 \\
\hline Voetgangersgebied & 598 & 1 & 7.434 & 2.515 \\
\hline Inrit & 10.022 & 12 & 9 & 12 \\
\hline Fietspad & 5.870 & 7 & 4 \\
\hline Ruiterpad & 9 & 2 & 1.207 \\
\hline Woonerf & 1.478 & 28 & 11.463 \\
\hline Rijbaan lokale weg & 22.908 & 100 & 63.225 \\
\hline Totaal & 81.715 & 18 & 12 \\
\hline
\end{tabular}

Door deze selecties verdwijnen er wel wegdelen die eigenlijk meegenomen hadden moeten worden. Deze kunnen handmatig weer worden toegevoegd, aangezien alle wegdelen in principe aanwezig zijn. Voor deze pilot met zoveel loopmogelijkheden is dat handmatig toevoegen ondoenlijk en zijn deze wegdelen verwijderd. Dit is het geval wanneer een fietspad of rijbaan een klein deel van een voetpad raakt en daardoor in de buffer valt, bijvoorbeeld bij een T-kruising.

Door deze bewerkingen zijn ook sommige wegdelen dubbel geselecteerd. Deze dubbellingen zijn verwijderd, waardoor er een uniek loopbestand is gemaakt waarop de berekeningen zijn uitgevoerd. Er zijn wegdelen met een zeer kleine oppervlakte. Deze 937 snippers van $1 \mathrm{~m}^{2}$ zijn verwijderd voor de berekeningen. Evenals 12 wegdelen waar geen lengte voor is. In totaal blijven er 63.225 loopmogelijkheden over (tabel B3.1).

\section{B3.2 Eenheden van indicatoren}

Er zijn indicatoren die negatief werken op de loopbaarheidsscore en indicatoren die positief werken. Een aantal indicatoren (zoals een terras) kan zowel negatief (barrière op voetpad) als positief (aantrekkelijk) werken.

De volgende hoofdlijnen voor bewerking bij de eenheden zijn aangehouden:

Alle rastereenheden: gemiddelde score van rasterscores per wegdeel

Alle lengte-eenheden: lengte indicator gedeeld door lengte wegdeel $* 100=$ percentage

Alle punteenheden: aantal punten van een indicator gedeeld door lengte wegdeel

Alle attribuuteenheden: ja of nee per wegdeel oftewel 1 of 0

Van een aantal indicatoren zijn er alleen data beschikbaar op een ander schaalniveau dan op voetpadniveau zoals op gemeenteniveau. Deze data zijn voor wegdelen niet onderscheidend en worden in dit pilotproject niet verder uitgewerkt. Dit betreft 13 indicatoren ( $8 \%$ ) van het totaal aan 160 indicatoren.

\section{B3.3 Ov-knooppunt}

Er zijn 38 openbaar vervoer (Ov)-knooppunten opgenomen in dit project. 28 daarvan zijn treinstations en 10 zijn bushaltes. Als pilotgebied is een cirkel van $300 \mathrm{~m}$ rond het Ov-knooppunt genomen en zijn binnen deze cirkel alle buurten geselecteerd. Binnen deze buurten zijn alle wegdelen uit tabel B3.1 
geselecteerd, waarbij een wegdeel over de volle lengte meegenomen wordt en dus niet wordt afgesneden op de grens van een buurt. Dit betekent in sommige gevallen dat er ook wegdelen opgenomen zijn die niet binnen de bebouwde kom liggen. Dat heeft als voordeel dat we in dit pilotproject een completer overzicht krijgen van de mogelijkheid om de loopbaarheid te kunnen meten. De 38 knooppunten liggen in 151 buurten en in 58 wijken en 19 gemeenten in de provincie Utrecht.

\section{B3.4 Indicatoren per wegdeel}

Hieronder worden de normenindeling en type berekeningen beschreven van een indicator per wegdeel. In de kolom "percentage" is de score opgeschaald naar 100 . Het is dus soms niet echt een percentage. Tevens wordt aangegeven of een indicator positief of negatief scoort op het totaaloordeel over de loopmogelijkheid. Als volgorde is zoveel mogelijk de indeling van de provincie Utrecht aangehouden, namelijk:

- Begrijpelijke Infrastructuur

- Omgevingskwaliteit

- Directheid

- Toegankelijk

- Levendigheid

- Allure

- Veiligheid

- Aantrekkelijkheid

- Bewegwijzering

\section{B3.5 Begrijpelijke infrastructuur}

Bij deze hoofdindicator gaat het om de infrastructuur bestaande uit de Loopmogelijkheden, Dichtheid aan loopmogelijkheden en Modaliteitsscheiding. De indicator Dichtheid aan kruispunten is vooralsnog niet meegenomen in de berekening.

\section{B3.5.1 Loopmogelijkheden}

De loopmogelijkheden zijn uit de BGT gehaald. Het blijkt echter dat niet alle voetpaden zijn ingevoerd wanneer het bestand wordt vergeleken met de voetpaden uit Openstreetmap. Openstreetmap lijkt completer, alleen is dat een lijn en geen polygoon, zodat de breedte niet te bepalen is. De toegekende punten zijn gebaseerd op de exclusiviteit om te lopen. Voetpaden in een voetgangerszone scoren het best en daarna voetpaden langs straten. Als er geen voetpad is, kan er eventueel op een fietspad gelopen worden, maar dat is minder veilig en rustig. Als er alleen op de straat kan worden gelopen, scoort dit het slechtst. De vrij liggende wandelpaden zijn een selectie van voetpaden die in een plantsoen, park, recreatiegebied, sportterrein, volkstuin, natuur of bos liggen en niet direct naast een straat in deze gebieden. Vrij liggende fietspaden zijn fietspaden die niet direct langs straten liggen.

\begin{tabular}{lr} 
Type loopmogelijkheid & 5 \\
Voetgangerszone/pleintjes & 5 \\
\hline Vrijliggende wandelpaden zonder naam (bijv. in park) & 4 \\
\hline Voetpad & 4 \\
\hline Inrit & 3 \\
\hline Voetpad op trap & 2 \\
\hline Eigen Fietspad (dus geen fietsstrook op de weg) als er geen voetpad is & 1 \\
\hline Woonerf & 1 \\
\hline Ruiterpad & 0 \\
\hline Rijbaan (straat)
\end{tabular}


De wegdelen zijn verschillend in grootte; er zitten wegdelen in van $1 \mathrm{~m}$ lang, maar ook van $150 \mathrm{~m}$ lang. Dit is tot uitdrukking gebracht door de lengte te delen door 100 en vervolgens te vermenigvuldigen met de waarde van de indicator.

\section{B3.5.2 Modaliteitsscheiding}

Het aandeel van ruimte voor lopen vergeleken bij de ruimte voor andere modaliteiten. Maak buffer van $7 \mathrm{~m}$ rond voetpad, voetgangersgebied en voetpad op trap en kwantificeer het aantal direct aanliggende modaliteiten. Dat zijn de wegdelen fietspad, rijbaan, tram en spoorbaan, inrit en woonerf. Hoe meer andere modaliteiten, hoe lager de score. Deze indicator werkt dus negatief op de totaalscore.

\begin{tabular}{lc} 
Modaliteitsscheiding & Punten \\
Vrij liggend voetpad, plein of trap & 0 \\
\hline Voetpad +1 ander modaliteit & -1 \\
\hline Voetpad + 2 andere modaliteiten & -2 \\
\hline Voetpad +3 andere modaliteiten & -3 \\
\hline Voetpad +4 of meer andere modaliteiten & -4 \\
\hline
\end{tabular}

\section{B3.6 Omgevingskwaliteit}

Deze indicatoren hebben vooral betrekking op gezond kunnen lopen. De hoofdindicator Omgevingskwaliteit bestaat uit de indicatoren Geluidhinder, Luchtkwaliteit, Risico op wateroverlast, Hitte gevoelstemperatuur en Verkoelend effect van groen en blauw. Deze indicatoren zijn in de berekening meegenomen. Van de indicatoren Geluidshinder bromfietsen en scooter, Geurhinder wegverkeer en Geurhinder bedrijven zijn de data niet bewerkt.

\section{B3.6.1 Geluidhinder}

Data over geluidhinder zijn afkomstig van het RIVM en bevat de Lden in dB van gemeentelijke, provinciale wegen (gegevens uit 2017) en rijkswegen (gegevens uit 2017), railverkeer (gegevens uit 2016), luchtvaart (gegevens uit 2011), industrie (kentalraming), windturbines (gegevens uit 2015) op rasterniveau met een resolutie van $10 \mathrm{~m}$. De gemiddelde Lden van de rasters per wegdeel is berekend. Hoe hoger de gemiddelde Lden, hoe meer geluidbelasting. De score werkt negatief op de totaalscore.

\section{B3.6.2 Luchtkwaliteitsindex (LKI)}

De luchtkwaliteitsindex beschrijft de mix aan luchtvervuilende stoffen: fijnstof, ozon en stikstofdioxide. Deskundigen hebben de niveaus ingedeeld naar de mogelijke invloed op de gezondheid. De niveaus variëren van 1 (weinig luchtverontreiniging) tot 11 (veel luchtverontreiniging). De data zijn van het RIVM en komen uit het jaar 2018. De data zijn op rasterniveau met een resolutie van $10 \mathrm{~m}$. De gemiddelde LKI van de rasters is per wegdeel berekend. Hoe hoger de gemiddelde LKI, hoe meer vervuiling. De score werkt negatief op de totaalscore.

\section{B3.6.3 Risico op wateroverlast}

De kaart 'verharding per buurt' is afkomstig uit de Klimaateffectatlas en is gebruikt om deze indicator te meten. In deze kaart worden bomen, struiken, lage vegetatie en water in bevolkingskernen gezien als 'onverhard'. Voor de overgebleven gebieden is aangenomen dat de buurt verhard is. In buurten met veel verharding is de kans op wateroverlast groter. Alle wegdelen in een buurt krijgen deze score. Hoe hoger de score, hoe meer risico op wateroverlast. De score werkt negatief op de totalscore.

Bron: Atlas Natuurlijk Kapitaal en Top10NL. 


\section{B3.6.4 Hitte gevoelstemperatuur}

Gevoelstemperatuur is gebaseerd op een hete zomerdag op basis van volle zon en uit de wind. Ouderen en mensen met overgewicht hebben vaak eerder last van een hogere gevoelstemperatuur, doordat ze hun warmte minder kwijt kunnen aan de omgeving. Onderzoekers van Wageningen University \& Research hebben een gestandaardiseerde methode ontwikkeld waarmee op basis van open data de gevoelstemperatuur kan worden berekend. Witteveen+Bos heeft de kaart voor de gevoelstemperatuur ontwikkeld, in samenwerking met Wageningen University \& Research en stichting Climate Adaptation Services. Deze kaart is afkomstig uit de Klimaateffectatlas. De data zijn op rasterniveau met een resolutie van $2 \mathrm{~m}$. De gemiddelde $\mathrm{C}^{\circ}$ van de rasters is per wegdeel berekend. Hoe hoger de gemiddelde $\mathrm{C}^{\circ}$, hoe meer hitte. De score werkt negatief op de totaalscore.

\section{B3.6.5 Verkoelend effect van groen en blauw}

Het verkoelende effect is berekend via groen (bomen e.d.) en blauw (water) in stedelijke gebieden. Het stedelijk hitte-eiland (Urban Heat Index, UHI) effect zorgt ervoor dat de luchttemperatuur 's nachts niet daalt, waardoor gevoelige bevolkingsgroepen (baby's, kinderen, ouderen) gezondheidseffecten ondervinden. De kaart van RIVM Atlas Natuurlijk Kapitaal uit 2017 is gemaakt m.b.v. een model dat met jaargemiddelde temperaturen werkt, waardoor het niet geschikt is voor extreem warme zomerdagen of nachten. Het verkoelende effect van het groen en blauw op zijn omgeving is weergegeven in $\mathrm{C}^{\circ}$. Dit gebeurt door de daling in de actueel berekende UHI van de maximaal berekende UHI af te trekken. In de actueel berekende UHI zijn zowel de verkoelende effecten van groen en blauw op grotere schaal $(1 \mathrm{~km})$ rondom een locatie meegenomen (bijvoorbeeld de grotere uitstraling van een park of een meer) als de lokale verkoelende effecten van groen en blauw binnen een straal van $30 \mathrm{~m}$ (bijvoorbeeld straatbomen die de omgeving van schaduw en watertransport voorzien). De data zijn op rasterniveau met een resolutie van $10 \mathrm{~m}$. De gemiddelde index van de rasters is per wegdeel berekend. Hoe hoger de gemiddelde index, hoe meer verkoeling.

\section{B3.7 Directheid}

Bij deze hoofdindicator wordt gekeken in hoeverre er voorzieningen in de nabijheid liggen van de wegdelen. Het gaat daarbij om essentiële voorzieningen, zoals scholen, gezondheidszorg en voedselwinkels, maar ook om parken, leisurevoorzieningen en publieke gebouwen. Ook de hoeveelheid Ov-haltes is een aparte indicator.

\section{B3.7.1 Nabijheid essentiële voorzieningen}

Bereikbaarheid van voorzieningen: scholen, gezondheidszorg en vers voedsel.

Methode: Het bestand bedrijvenregister bevat deze gegevens. Alle supermarkten en voedingswinkels binnen $500 \mathrm{~m}$ van een wegdeel worden opgeteld, alle scholen en gezondheidszorginstellingen binnen 1000 m. Bronnen: bedrijvenregister BAG-functie "gezondheid" en "onderwijs". Supermarkten en voedingswinkels via OSM code: 2502, 2518, 2516, 2511, 2306, 2528, 2501.

\section{B3.7.2 Bereikbaarheid speeltuinen}

Methode: Gebruik de poi-laag speeltuinen, code 2205. Haal daaruit alle speeltuinen binnen $500 \mathrm{~m}$. Bepaal of een wegdeel binnen de buffer valt.

\section{B3.7.3 Bereikbaarheid leisurebestemming op loopafstand}

Bereikbaarheid van restaurants, café, theater, musea, bioscoop, winkels (niet zijnde voedsel)

Methode: Gebruik het bestand uit de Openstreetmap de poi-laag. Haal daaruit alle relevante POI's en tel alle punten binnen $500 \mathrm{~m}$ van een wegdeel. OSM code: 2733, 2014, 2721, 2305, 2529, 2566, 2542, 2515, 2303, 2731, 2203, 2512, 2546, 2505, 2206, 2543, 2302, 2513, 2544, 2547, 2521, 2561, 
2520, 2083, 2503, 2568, 2007, 2504, 2724, 2525, 2723, 2722, 2202, 2519, 2524, 2101, 2741, 2304,

2301, 2732, 2421, 2517, 2251, 2522, 2253, 2201, 2701, 2526, 2593, 2742, 2743.

\section{B3.7.4 Bereikbaarheid publiek gebouwen op loopafstand}

Bereikbaarheid van banken, gemeentehuis, politiekantoor etc.

Methode: Gebruik het BAG-functiebestand en selecteer daaruit "kantoor" en "bijeenkomsten" en tel alle punten binnen $500 \mathrm{~m}$ van een wegdeel.

\section{B3.7.5 Fijnmazigheid OV}

Ov-(haltes) mogelijkheden

Methode: Gebruik het ov-bestand uit bestand van de RUG. Tel alle relevante POI's binnen $800 \mathrm{~m}$ (zie studie invloedssfeer Ov van Sweco) van een wegdeel. Er is een heatmap gemaakt met 25 m-resolutie, waarbij binnen een straal van $800 \mathrm{~m}$ wordt gekeken hoeveel "public_transport_stops" binnen bereik zijn. Resultaat is een floating point getal.

(Bronnen: Ov-haltes van de Rijksuniversiteit Groningen)

\section{B3.8 Toegankelijkheid}

\section{B3.8.1 Lengte van voetpad, connectiviteit}

Hoe korter de lengte, hoe groter de connectiviteit. De wegdelen zijn polygonen die soms een grillige vorm hebben, waardoor de lengte niet goed te berekenen valt. Daarom is de lengte van de polygonen berekend met de FME-techniek, die een centrumlijn berekent via de optie Approximate Center Line. Nadeel van deze techniek is dat de centrumlijn niet altijd tot de grens van de polygoon loopt, maar soms 1 à 3 m ervandaan blijft. Van 18 wegdelen is de lengte $0,00 \mathrm{~m}$.

Alleen de lengte van een wegdeel is een beperkte vorm van connectiviteit meten, want de wegdelen eindigen niet altijd bij een kruispunt. En soms gaat een wegdeel de hoek om. De gemiddelde lengte van alle wegdelen in de onderscheiden buurten is $49 \mathrm{~m}$.

Te vaak oversteken geeft onrust, te weinig verbinding is saai. Molster \& Schuit (2021) schrijven dat te weinig prikkels saai zijn, te veel prikkels zijn stressvol (blz. 204). Uitgaande van $4 \mathrm{~km} / \mathrm{u}$ lopen, zou bij $250 \mathrm{~m}$ circa 4 minuten lopen zijn, ofwel $100 \mathrm{~m}$ is 1,5 minuut en $150 \mathrm{~m}$ is circa 2,22 minuut.

Volgende voorstel:

\begin{tabular}{lc} 
Afstand in $m$ voetpad/trottoir & Punten \\
\hline 0 & 0 \\
\hline $0-100$ & 2 \\
\hline $100-150$ & 3 \\
\hline 150 of meer & 1 \\
\hline
\end{tabular}

Uit TOD:

Alle blokken binnen het gebied zijn minder dan $110 \mathrm{~m}$ lang $\quad 10$ Alle blokken binnen het gebied zijn minder dan $130 \mathrm{~m}$ lang 6 Alle blokken binnen het gebied zijn minder dan $150 \mathrm{~m}$ lang 2 Sommige blokken binnen het gebied zijn meer dan $150 \mathrm{~m}$ lang 0 


\section{B3.8.2 Loopbreedte}

Vrije breedte van de looproute bij voorkeur minimaal $1,80 \mathrm{~m}$ en in ieder geval 1,50 $\mathrm{m}$. Vrije breedte incidentele route mag 1,20 m zijn als er minder dan $20 \mathrm{~m}$ afstand te overbruggen is. Vrije breedte plaatselijke doorgangen (tussen paaltjes) minimaal 0,90 m. Drukke winkelstraten uitgaan van een breedte van 2,40 m tot 4,00 m. Bron: https://www.verkeerskunde.nl/Uploads/2017/10/handboeknijmegen-toegankelijk-nov-2016-.pdf. Zie ook Molster blz. 151/152.

De loopbreedte wordt berekend door de omtrek van het polygoonwegdeel te delen door de lengte. Aangezien een polygoon een grillig verloop kan hebben (zie afbeelding) en dus ook de lengte, wordt de breedte bepaald door de gemiddelde breedte. Soms is de lengte heel klein, maar de oppervlakte groot. Dan wordt er een grote breedte berekend. Bij 12.272 wegdelen (19\%) is de breedte hierdoor groter dan de lengte. Bij 8.465 wegdelen (13\%) is de breedte zelfs meer dan tweemaal zo groot als de lengte.

Uitgangspunt is hoe breder, hoe beter.

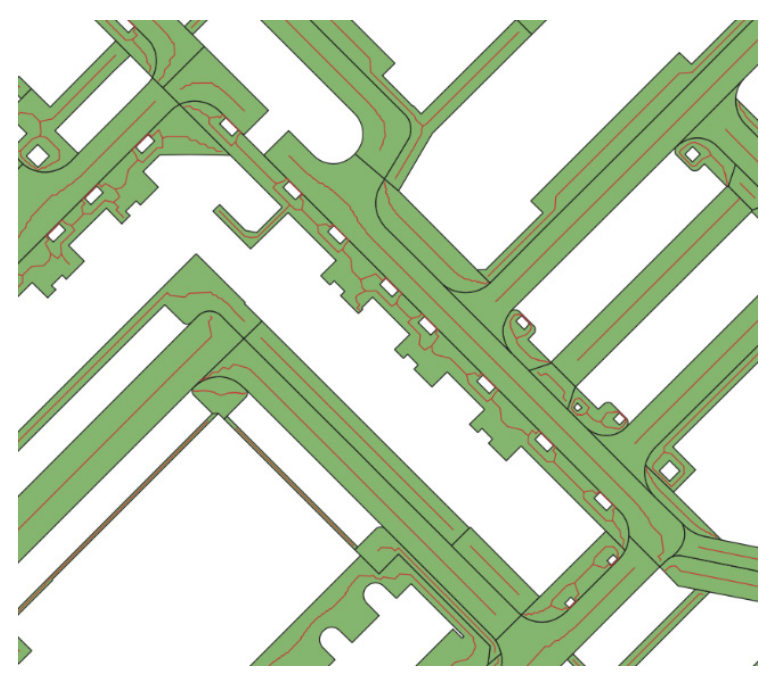

Afbeelding Ontbrekende delen in de lengte van een lijn en grillige vormen van de centrumlijn.

Door ontbrekende delen in de lengte van een lijn en grillige vormen van de centrumlijn is het niet altijd goed om de breedte te berekenen.

\section{B3.8.3 Verharding}

Type verharding van de voetpaden ten behoeve van het fysieke comfort \& veiligheid. Hoe meer verhard, hoe meer geschikt voor diverse doelgroepen. Verharding komt overeen met indicator materiaalkeuze.

\begin{tabular}{ll} 
Type verharding & Punten \\
Gesloten & 4 \\
\hline Open verharding & 3 \\
\hline Half verhard & 2 \\
\hline Onverhard & 1 \\
\hline
\end{tabular}

\section{B3.8.4 Molgoten}

Maak buffer van $1 \mathrm{~m}$ rond wegdeel. Lengte aan molgoot gedeeld door lengte wegdeel maal 100 . Hoe langer de molgoot is, hoe beter de score. 


\section{B3.8.5 Geleidelijnen}

Mol- of roostergoot kan dienen als gidslijn (Molster, blz. 145), naast de BGT-indicator geleidelijn. Selecteer molgoten die niet nabij $(1 \mathrm{~m})$ geleidelijnen liggen. Maak buffer van $1 \mathrm{~m}$ rond wegdeel. Lengte aan geleidelijn en molgoten gedeeld door lengte wegdeel maal 100 . Hoe langer de geleidelijn is, hoe beter de score.

\section{B3.8.6 Abri bolder brievenbus reclamebord fietsenrek telefooncel boomspiegel prullenbak parkeermeter container, glasbak, recycling verkeersbord kast openbaar toilet}

Maak buffer van $1 \mathrm{~m}$ rond wegdeel. Aantal van aparte indicator gedeeld door lengte wegdeel maal 100. Dit zijn allemaal barrières voor de loopbreedte, dus werken negatief. Dus hoe meer, hoe lager de score.

\section{B3.9 Levendigheid}

\section{B3.9.1 Leegstaande en vervallen gebouwen}

Een pand(en) met (leegstaande) verblijfsobject(en) is in dusdanige bouwkundige staat geraakt dat niet te verwachten is dat het pand zal worden hersteld en weer in gebruik zal worden genomen (BAG). De status van het pand(en) en bijbehorende verblijfsobject(en) zijn op 'buiten gebruik' gezet. Leegstand beperkt de levendigheid en werkt dus negatief op de loopscore. Maak buffer van $1 \mathrm{~m}$ rond wegdeel. Aantal van leegstaande verblijfsobjecten gedeeld door lengte wegdeel maal 100.

\section{B3.9.2 Bankjes}

Data bestaan uit een combinatie van OSM en BGT. Bij BGT het aantal bankjes geteld per wegdeel en bij OSM indien een bankje niet verder weg staat dan $10 \mathrm{~m}$ van een wegdeel.

Maak buffer van $1 \mathrm{~m}$ rond wegdeel. Aantal bankjes gedeeld door lengte wegdeel maal 100 .

\section{B3.9.3 Speeltuin/voorziening als ontmoeting}

Op de Openstreetmap staan speeltuinen getekend die niet in het bestand zitten; ook niet bij BGT. BGT lijkt afzonderlijke spelelementen te tellen. Eén speeltuin bij OSM geeft 25 speeltuinen bij BGT. Daarom alleen de waarde 1 gekozen, tenzij er twee speeltuinen worden genoemd (dat kan bij een lang wegdeel voorkomen).

Maak buffer van $1 \mathrm{~m}$ rond wegdeel. Aantal van speeltuinen gedeeld door lengte wegdeel maal 100 .

\section{B3.9.4 Diversiteit, Menging wonen en werken en Wonen}

In de BAG worden de volgende functie onderscheiden: woonfunctie, bijeenkomst, gezondheid, industrie, kantoor, logies, onderwijs, sport, winkels en overig. ${ }^{9}$ Tevens wordt de oppervlakte van het pand gegeven. Bereken het totaalaantal panden van een wegdeel binnen een buffer van $10 \mathrm{~m}$. Bepaal hierin het aantal panden met een woonfunctie. Deel aantal met woonfunctie door het totaal keer honderd. Hoe meer woningen, hoe lager de gemengde functies en dus hoe lager de score. Een percentage van $0 \%$ woningen wordt verwijderd, want dan is er ook geen menging.

\section{B3.9.5 Overkapping}

Maak buffer van $1 \mathrm{~m}$ rond wegdeel. Selecteer uit BGT luifel uit het niet-BGT_vlak. Aantal luifels gedeeld door lengte wegdeel maal 100.

\footnotetext{
9 En celfunctie, maar die komt haast niet voor.
} 


\section{B3.9.6 Bedrijvigheid van plint}

Bedrijvigheid van de plint is een mix van functies (met name Leisure en voedsel). Alle OSM-codes die bij deze winkels horen (zie boven) worden geselecteerd, dus alle OSM met een voordeur. Zie molster blz. 204/205. Aantal OSM-punten per wegdeel gedeeld door lengte wegdeel maal 100.

\section{B3.9.7 Pleintje als ontmoeting}

Methode: Selecteer uit BGT voetgangersgebied van minimaal 0,1 ha en minimale lengte en breedte van $25 \mathrm{~m}$, verhard en niet in een groengebied.

Maar dit gaat niet helemaal goed. Er vallen te veel pleintjes af. Misschien beter om op naam "plein" of "markt" te selecteren.

\section{B3.10 Allure}

\section{B3.10.1 Oude gebouwen}

Maak buffer van $3 \mathrm{~m}$ rond wegdeel. Selecteer gebouwen ouder dan 1850. Aantal oude gebouwen gedeeld door lengte wegdeel maal 100.

\section{B3.10.2 Theater, musea, kastelen en overig Leisure}

Maak buffer van $10 \mathrm{~m}$ rond wegdeel. Aantal van Leisure gedeeld door lengte wegdeel maal 100. Zie ook OSM. Codes: dit zijn dezelfde code als bij Leisure dus: 2733, 2014, 2721, 2305, 2529, 2566, 2542, 2515, 2303, 2731, 2203, 2512, 2546, 2505, 2206, 2543, 2302, 2513, 2544, 2547, 2521, 2561, 2520, 2083, 2503, 2568, 2007, 2504, 2724, 2525, 2723, 2722, 2202, 2519, 2524, 2101, 2741, 2304, 2301, 2732, 2421, 2517, 2251, 2522, 2253, 2201, 2701, 2526, 2593, 2742, 2743.

\section{B3.10.3 Rijksmonumenten}

Rijksmonumenten komen uit het bestand van de provincie Utrecht, namelijk CHAT Cultuurhistorische Atlas Utrecht. Daar zijn alle punten, vlakken en lijnen geselecteerd die op $10 \mathrm{~m}$ van een wegdeel afliggen en bij elkaar opgeteld.

\section{B3.10.4 Boulevard, wandelpromenade}

Boulevard en wandelpromenade zijn brede voetpaden. Selecteer voetpaden breder dan $10 \mathrm{~m}$, niet zijnde een winkelstraat en minimaal $200 \mathrm{~m}$ lang.

\section{B3.10.5 Hoogte gebouwen}

Het bestand BAG_panden en dan BAG_3D kan hiervoor gebruikt worden met de kolom pandhoogte. Alle panden $50 \mathrm{~m}$ of hoger zijn geselecteerd op maximaal $10 \mathrm{~m}$ afstand van een loopmogelijkheid.

\section{B3.11 Veiligheid}

\section{B3.11.1 Parkeerplaats auto's}

Door middel van een parkeervak is er een scheiding tussen voetpad en het verkeer op de straat (dus veiliger). Bepaal de lengte uit de BGT-parkeervlakken die binnen een 1m-buffer van een wegdeel ligt. Probleem is dat soms de parkeervakken niet evenwijdig aan de straat/voetpad liggen, maar er loodrecht of schuin op staan. In dat geval moet niet de lengte, maar de breedte worden genomen. Het is echter niet automatisch te achterhalen of een parkeervak evenwijdig of loodrecht ligt. Soms ligt een parkeervak net binnen $1 \mathrm{~m}$ van een voetpad dat voor de rest in een groenstrook ligt. Dan wordt dat voetpad toch 
geselecteerd en gedeeld door de lengte van de parkeervakken die slechts $1 \mathrm{~m}$ overlap hebben (zie rood omlijnd in figuur waarbij donkergroen het parkeervak is en bruin het voetpad). Andersom gebeurt ook. Om dit te voorkomen, zijn alle parkeervakken verwijderd die meer dan $100 \%$ van een wegdeel als waarde geven.

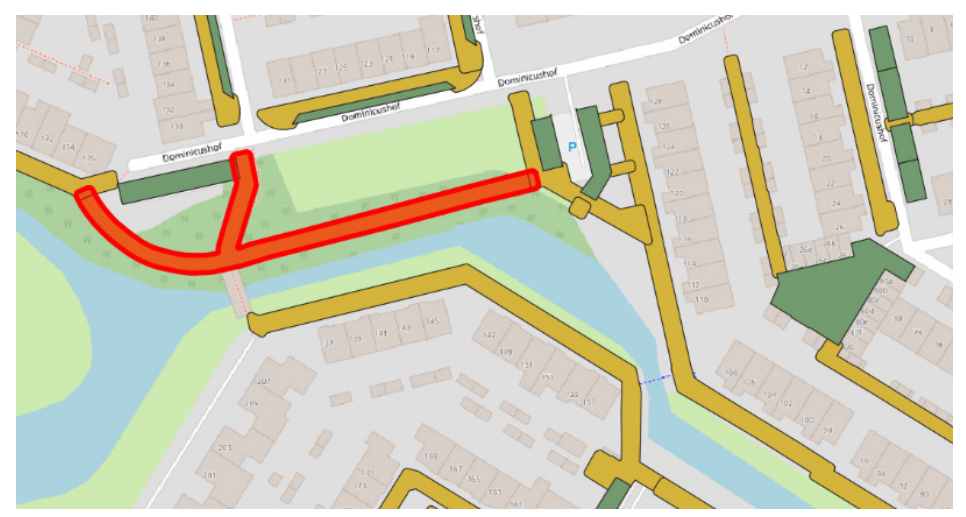

Hoe meer parkeervlakken, hoe veiliger en dus beter.

\section{B3.11.2 Maximumsnelheid}

Uit NWB-bestand de snelheid halen van de straten. Bepaal de snelheid van straat die binnen $3 \mathrm{~m}$ buffer van voetpad of fietspad ligt. Het NWB-bestand geeft dan soms meer straten die binnen de buffer vallen. In dat geval is de gemiddelde snelheid berekend. Hoe hoger de gemiddelde snelheid, hoe meer onveilig. De score werkt negatief op de totaalscore.

\section{B3.11.3 Verkeerseiland, Oversteken vluchtheuvel}

Maximale oversteeklengte korter dan $7 \mathrm{~m}$ bij een niet-geregelde oversteek. Vluchtheuvel toepassen bij een grotere oversteek ( $>7 \mathrm{~m}$ ). De vluchtheuvel heeft een opstelruimte groter dan $2 \mathrm{~m}$ in oversteekrichting en loopoppervlak gelijk aan de rijbaan. Selecteer alle straten breder dan $7 \mathrm{~m}$ en alle verkeerseilanden. Trek een buffer van $12 \mathrm{~m}$ rond verkeerseilanden. Alle voet- en fietspaden die binnen deze buffer vallen, krijgen 1 punt. De overige paden die langs straten van meer dan 7 m liggen, krijgen 0 punten.

\section{B3.11.4 Verlichting}

Maak buffer van $1 \mathrm{~m}$ rond wegdeel. Aantal verlichtingspalen gedeeld door lengte wegdeel maal 100 .

\section{B3.11.5 Berm}

Door middel van een berm is er een scheiding tussen voetpad en het verkeer op de straat, dus veiliger. Bepaal de lengte uit de BGT bermen en groenvoorziening die binnen 1m-buffer van wegdeel ligt.

\section{B3.11.6 Cameratoezicht}

Maak buffer van $1 \mathrm{~m}$ rond wegdeel. Aantal camera's uit OSM gedeeld door lengte wegdeel maal 100.

\section{B3.11.7 Verkeersremmend}

BGT: niet-BGT: verkeersdrempel van het wegdeel straat, geldend voor voet- en fietspaden aan beide zijden van de straat. Selecteer alle verkeersdrempels. Trek een buffer van $5 \mathrm{~m}$ rond verkeersdrempel. Alle voet- en fietspaden die binnen deze buffer vallen, krijgen 1 punt. 


\section{B3.11.8 Verkeerafsluitende straat}

BGT: niet-BGT: poller/afsluitpaal/slagboom van het wegdeel straat, geldend voor voet- en fietspaden aan beide zijden van de straat. Selecteer alle poller/afsluitpaal/slagboom. Trek een buffer van $5 \mathrm{~m}$ rond poller/afsluitpaal/slagboom. Alle voet- en fietspaden die binnen deze buffer vallen, krijgen 1 punt. De overige paden krijgen 0 punten.

\section{B3.11.9 Richtingsverkeer}

Uit de shapefile wegvakken van het NWB is de rijrichting bekend vanaf 1 april 2020. $\mathrm{H}$ (heen) en $\mathrm{T}$ (terug) is eenrichting; $\mathrm{B}$ (beide) is tweerichting. Maak een buffer van $10 \mathrm{~m}$ rond de lokale weg en alle voet- en fietspaden binnen deze buffer krijgen de rijrichtingpunten.

\section{B3.11.10 Verkeerslichten, Drukknoppaal}

Maak buffer van $1 \mathrm{~m}$ rond wegdeel uit het BGT-bestand. Alle voet- en fietspaden binnen deze buffer krijgen het aantal verkeerslichten en drukknoppalen. Hoe meer, hoe veiliger.

\section{B3.11.11 Zebra}

OSM 5204 zebra van het wegdeel straat, geldend voor voet- en fietspaden aan beide zijden van de straat. Maak een buffer van $3 \mathrm{~m}$ rond zebra en selecteer de wegdelen binnen de buffer en geef hieraan 1 punt. In OSM is er maar 1 zebra gevonden. Hoe meer zebra's, hoe hoger de score.

\section{B3.12 Aantrekkelijkheid}

\section{B3.12.1 Beelden, Fonteinen, Herdenkingsmonument}

Maak buffer van $1 \mathrm{~m}$ rond wegdeel uit het BGT-bestand. In BGT is er geen herdenkingsmonument in geselecteerde buurten. Alle wegdelen in de buffer krijgen de gesommeerde aantallen.

\section{B3.12.2 Gevelverdeling}

Gebruik het BAG-bestand. Selecteer alle panden binnen $1 \mathrm{~m}$ van een wegdeel. Sommeer het aantal panden per wegdeel. Uit Molster et al. (blz. 204) blijkt dat een ideale gevelverdeling 15 tot 20 panden per $100 \mathrm{~m}$ heeft, ofwel 0,15-0,2 per $\mathrm{m}$. Selecteer alle wegdelen van $50 \mathrm{~m}$ of langer. Deel het aantal panden door de lengte van het wegdeel. Alle wegdelen met een score tussen 0,15-2 krijgen 1 punt. De overige 0 punten.

\section{B3.12.3 Bomen}

Het bomenregisterbestand uit 2019 is gebruikt. De kruinen van de bomen zijn als polygonen in dit bestand weergegeven. De centroïde van de polygonen is aangemaakt als geldend voor de boomstam. De centroïdes worden vervolgens gekruist met het wegdelenbestand en vervolgens wordt het aantal boomstammen per wegdeel opgeteld. Hoe meer boomstammen, hoe beter.

1. Kwantificeer de totale lengte van wegdeel en deel dat door 100.

2. Kwantificeer het aantal bomen in een wegdeel.

3. Deel de tweede maatstaf door de eerste maatstaaf om het percentage bomen te berekenen.

\section{B3.12.4 Houtwal}

Terreindeel zijnde een afscheiding met beperkte breedte en beplant met bomen of struiken. Indien een wegdeel een houtwal heeft binnen een buffer van $5 \mathrm{~m}$, krijgt het wegdeel een punt.

\section{B3.12.5 Berm (Lage Vegetatie)}

Ga naar het bestand BGT, binnen Ondersteunend Wegdeel de berm en groenvoorziening. Selecteer de bermen binnen $5 \mathrm{~m}$ van een wegdeel. 
B3.12.6 Beek, rivier, kanaal, sloot, gracht, vijvers, greppel/droge, oever

Selecteer deze indicatoren indien ze binnen $10 \mathrm{~m}$-buffer liggen van een wegdeel. Indien een wegdeel deze indicator heeft, krijgt het wegdeel een punt. In BGT de indicator dus geselecteerd met 1/0.

\section{B3.12.7 Voortuinlengte}

In BGT zijn de polygonen van erven grillig. Daarom is de lengte van gedeelde grenzen tussen twee polygonen als volgt te bepalen:

Stel je hebt twee polygonen A (geel) en B (roze) die een stukje aan elkaar grenzen:

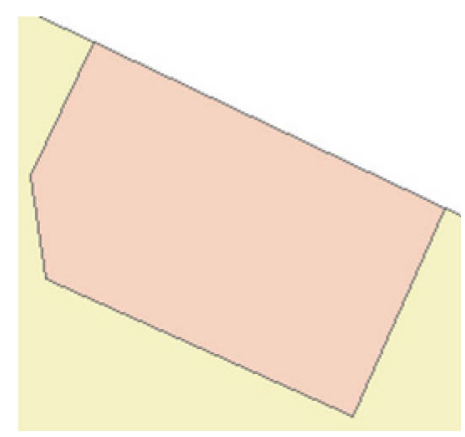

Converteer polygoon A tot polyline $A$ (rood)

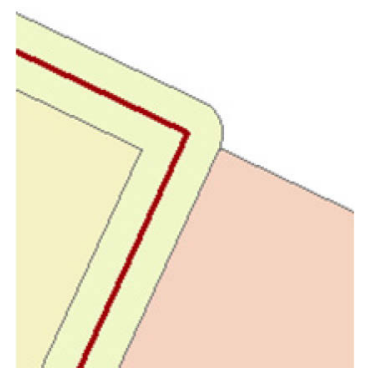

Maak er een buffer (lichtgroen) omheen van $1 \mathrm{~cm}$ (moet kleine maat hebben t.o.v. afmetingen van feature)

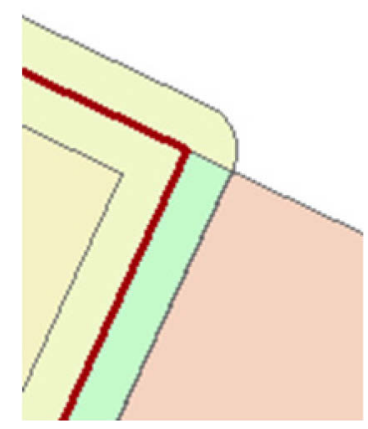

Intersect deze buffer met polygoon B

\begin{tabular}{|r|r|}
\hline Shape Length & Shape Area \\
\hline 13.519098 & 0.067358 \\
\hline
\end{tabular}

De lengte van de gedeelde grens is nu de helft van de omtrek (Shape_Length) van de intersectpolygoon (groen). Deze heeft de onderstaande omtrek en oppervlakte (in $\mathrm{m}$ resp. $\mathrm{m}^{2}$ ) 
Onderbouwing: de intersectpolygoon heeft geringe oppervlakte (want is maar $1 \mathrm{~cm}$ breed) en relatief grote omtrek (13.52 m). In de omtrek ( $2 x$ de lengte $+2 x$ de breedte) is het aandeel van de lengte $99,8 \%$. Daarom zal de helft van de omtrek (6.76) een goede indicatie zijn voor de lengte van de gedeelde grenslijn.

Lengte wegdeel met deze indicator binnen $5 \mathrm{~m}$ buffer. Voor- en achtertuinen van panden worden in BGT-v beschouwd als onderdeel van het erf (onbegroeid terreindeel): terreindeel dat bij een pand of overig bouwwerk hoort, dat niet nader wordt ingewonnen en dat bestaat uit een mengvorm van begroeiing, verharding en/of water.

\section{B3.12.8 Gemengd groen landgebruik}

Hoe meer gevarieerd groen landgebruik, hoger de score. De volgende landgebruikscategorieën uit bestand bodemgebruik 2015 (BBG2015) zijn gebruikt: begraafplaats, agrarisch gebied, grasland, sportterrein, bos, natuurlijk terrein (droge en natte natuur), parken en plantsoenen, recreatieterrein, en volkstuin. Uit BGT zijn hagen geselecteerd. Selecteer al de landgebruikscategorieën uit bestand bodemgebruik 2015 (BBG2015) c.q. BGT binnen 5m-buffer van een wegdeel. Indien een wegdeel deze indicator heeft, krijgt het wegdeel een punt. De score is de som van al deze indicatoren gedeeld door het totaal aan deze indicatoren (10).

\section{B3.12.9 Groene uitstraling}

Het bomenkaartbestand van WENR is gebruikt. Via remote sensing is het groen in rasters van $10 \mathrm{x}$ $10 \mathrm{~m}$ opgenomen. Dus ook het groen op particulier terrein is hierbij meegenomen. Raster zijn over de wegdelen gelegd en de waarden zijn per wegdeel opgeteld. Vervolgens is dit getal gedeeld door de lengte van het wegdeel. Het kan dus zijn dat een raster over meer wegdelen valt, bv. een straat met aan één kant een voetpad met bomen en aan het tegenoverliggende voetpad geen bomen. Toch krijgen beide voetpaden (en straat) dezelfde waarden, omdat ze in hetzelfde raster liggen. Dit noemen we de groene uitstraling.

\section{B3.12.10 Hondenuitlaatplaats, hoogspanningsmast, Afvalbak, Bloembak, Uitzichtpunt}

Maak buffer van $1 \mathrm{~m}$ rond wegdeel uit het BGT-bestand en OSM-bestand.

\section{B3.12.11 Windhinder}

Kans op windhinder bij gebouwen die hoger zijn dan $15 \mathrm{~m}$ en max. $5 \mathrm{~m}$ van wegdeel. Het bestand BAG_panden en dan BAG_3D kan hiervoor gebruikt worden met de kolom pandhoogte.

\section{B3.12.12 Beschutting zon en regen}

Methode: Voor het bepalen van beschutting zijn bomen en (Ov-)haltes genomen, luifels en shelter POI. Deze worden geteld binnen $3 \mathrm{~m}$ afstand van wegdelen.

Bronnen: BRK, NWB, BGT, Open OV data. In BGT-bestand, niet_BGT_v luifel.

\section{B3.13 Bewegwijzering}

\section{B3.13.1 Toeristische informatie, Straatnaambordje, Wegwijzers, Overzichtskaart}

OSM code 2704, 2705, 2706 en niet-BGT_P. Maak buffer van $1 \mathrm{~m}$ rond wegdeel. 
Wageningen Environmental Research Postbus 47

6700 AA Wageningen

T 0317480700

www.wur.nl/environmental-research

Wageningen Environmental Research

Rapport 3101

ISSN 1566-7197
De missie van Wageningen University \& Research is 'To explore the potential of nature to improve the quality of life'. Binnen Wageningen University \& Research bundelen Wageningen University en gespecialiseerde onderzoeksinstituten van Stichting Wageningen Research hun krachten om bij te dragen aan de oplossing van belangrijke vragen in het domein van gezonde voeding en leefomgeving. Met ongeveer 30 vestigingen, 6.800 medewerkers ( $6.000 \mathrm{fte}$ ) en 12.900 studenten behoort Wageningen University \& Research wereldwijd tot de aansprekende kennisinstellingen binnen haar domein. De integrale benadering van de vraagstukken en de samenwerking tussen verschillende disciplines vormen het hart van de unieke Wageningen aanpak. 


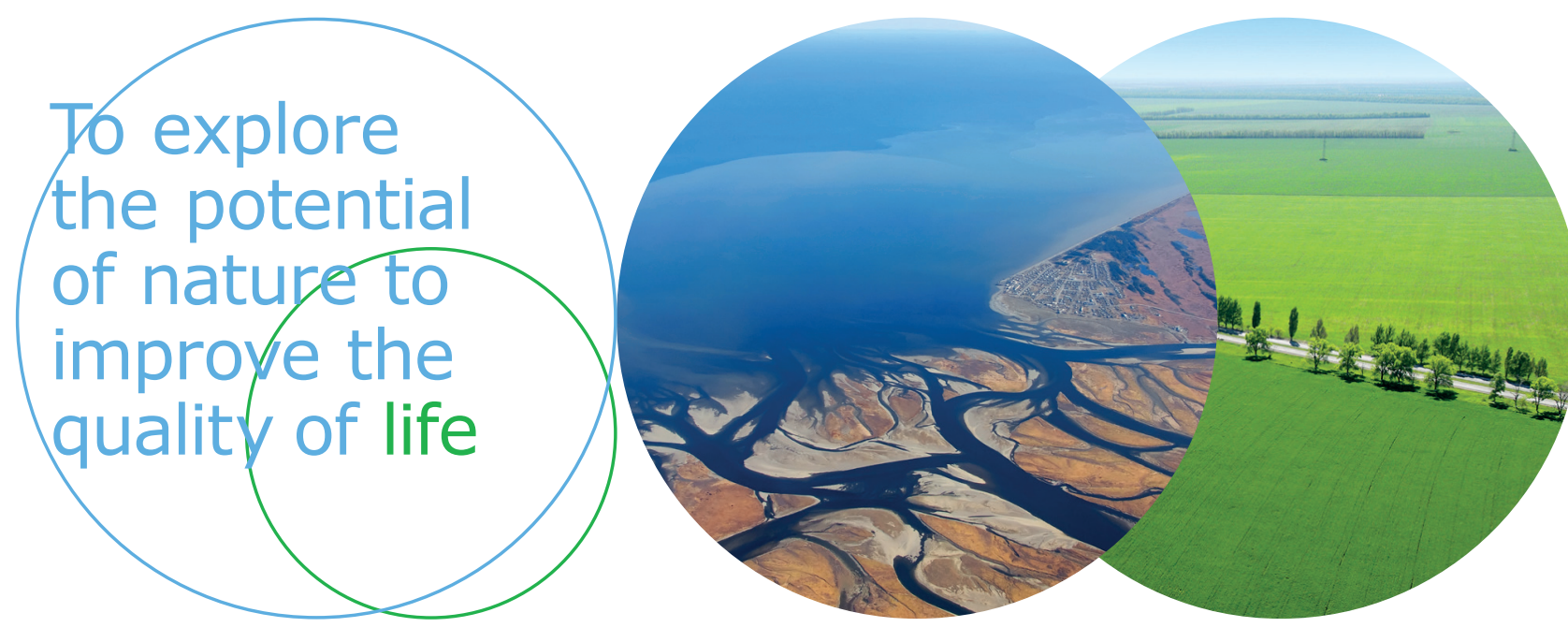

Wageningen Environmental Research Postbus 47

$6700 \mathrm{AB}$ Wageningen

T 317480700

www.wur.nl/environmental-research

Rapport 3101

ISSN 1566-7197
De missie van Wageningen University \& Research is 'To explore the potential of nature to improve the quality of life'. Binnen Wageningen University \& Research bundelen Wageningen University en gespecialiseerde onderzoeksinstituten van Stichting Wageningen Research hun krachten om bij te dragen aan de oplossing van belangrijke vragen in het domein van gezonde voeding en leefomgeving. Met ongeveer 30 vestigingen, 6.800 medewerkers (6.000 fte) en 12.900 studenten behoort Wageningen University \& Research wereldwijd tot de aansprekende kennisinstellingen binnen haar domein. De integrale benadering van de vraagstukken en de samenwerking tussen verschillende disciplines vormen het hart van de unieke Wageningen aanpak. 